\title{
El carácter multidimensional de la imparcialidad administrativa y el principio de objetividad: reflexiones sobre la experiencia italiana ${ }^{1}$
}

\author{
Massimo Monteduro \\ Investigador Confirmado de Derecho Administrativo \\ en la Facultad de Derecho de la Università degli Studi del Salento \\ massimo.monteduro@unisalento.it
}

\begin{abstract}
Resumen
Mientras la Constitución española (art. 103) consagra expresamente el principio de "objetividad" de la actuación administrativa, en el mismo artículo en el que se enuncia a continuación el principio de "imparcialidad", la Constitución italiana (art. 97) establece el principio de "imparcialidad" administrativa, sin emplear, en ningún caso, la locución "objetividad". Asimismo, la Ley general de procedimiento administrativo italiana (L. 241/1990), al fijar los principios generales de la actividad administrativa, sigue el mismo esquema. Sin embargo, examinando el Ordenamiento jurídico italiano, se puede observar que, en numerosas ocasiones, tanto en la normativa vigente como en la jurisprudencia se hace referencia expresa al principio (o canon o criterio) de "objetividad" de la actuación de la Administración. A la luz de estos síntomas, parece oportuno preguntarse sobre la existencia y la consistencia del paradigma de la "objetividad" administrativa en el Derecho italiano. En el presente trabajo se exploran las relaciones entre imparcialidad y objetividad. Del análisis de la jurisprudencia y de las fuentes normativas, parece desprenderse la tendencia a circunscribir la "objetividad" a un significado específico. El principio de objetividad, en este significado, se identifica con un deber de autolimitación, preventiva y analítica, por parte de las Administraciones públicas, a través de una autovinculación a criterios de valoración y esquemas procedimentales establecidos y publicados por las mismas Administraciones, con el fin de asumir posteriores decisiones no vinculadas completamente por la ley. El principio de objetividad, en sí mismo, puede ocupar un espacio autónomo dentro de un círculo más amplio representado por el
\end{abstract}

$1 \quad$ La atención a la multidimensionalidad de las categorías fundamentales del derecho tiene raíces profundas en la tradición de la doctrina italiana. Baste con recordar, por su fuerza icástica, el pensamiento de A. Falzea, Introduzione alle scienze giuridiche. 1. I/ concetto del diritto, Milán, Giuffré, 2008 (en especial véase el Capítulo I, “Avvio ad una definizione assiologica del diritto”, Sección I, “I caratteri incontroversi del diritto", párrafo 5, "Normatività e valore”). Falzea, tras haber proporcionado la "definición del derecho como necesidad de valor" (op. cit., p. 20), afirma que "la unicidad de la temática surge en concreto a través de su multidimensionalidad: las múltiples dimensiones, aunque diferentes, muestran un fondo de identidad en lo que se llama valor" (allí, p. 21). Así, en múltiples y varios ámbitos de la experiencia jurídica, la doctrina reciente ha podido llevar a la luz, por ejemplo, la "multidimensionalidad" del derecho a la educación (S. Stammati, L'ampliamento dei diritti culturali fra universalismo e particolarismo en A. Pisaneschi -L. Violini encargado, Poteri, garanzie e diritti a sessanta anni dalla Costituzione. Scritti per Giovanni Grottanelli de' Santi, vol. I, Padua, Cedam, 2007, p. 1352), o el carácter "multidimensional” del principio de subsidiariedad (C. Amirante, I diritti umani tra dimensione normativa e dimensione giurisdizionale?, en L. d'Avack [encargado], Sviluppo dei diritti dell'uomo e protezione giuridica, Nápoles, Guida, 2003, p. 37), o también el carácter “multidimensional" de la noción jurídica de medio ambiente en el sistema constitucional (M. Cecchetti, Ambiente, paesaggio e beni culturali, en G. Corso - V. Lopilato [encargado], I/ diritto amministrativo dopo le riforme costituzionali. Parte speciale, vol. I, Milán, Giuffrè, 2006, p. 315) y, más en general, la "multidimensionalidad" de los derechos constitucionales (P. Ridola, Diritti fondamentali. Un'introduzione, Turín, Giappichelli, 2006 y allí el Capítulo VII, titulado “Interpretazione e multidimensionalità dei diritti costituzionali”). 
principio de imparcialidad. La técnica de reducción de la parcialidad administrativa propia del principio de objetividad, en particular, parece consistir en la des-subjetivización de las valoraciones discrecionales de las Administraciones públicas.

\title{
The multi-dimensional nature of administrative impartiality and the principle of objectivity. Thoughts on the Italian experience
}

\begin{abstract}
Whilst the Spanish constitution (art. 103) expressly establishes the principle of "objectivity" in administrative procedure in the same article where the principle of "impartiality" is subsequently mentioned, the Italian constitution (art. 97) establishes the principle of administrative "impartiality" without mentioning the word "objectivity" at any time. Furthermore, the Italian general administrative procedure law (L. 241/1990) follows the same pattern in establishing the general principles of administrative activity. However, on examining the Italian legal system we come across many instances, both in the legislation in force and in case law, where specific reference is made to the principle (or canon or criterion) of "objectivity" in the action of the administration. In the light of these symptoms, it seems appropriate to question the existence and consistency of the paradigm of administrative "objectivity" in Italian law. This work explores the connections between impartiality and objectivity. An analysis of case law and the legislation sources points to a tendency to confine "objectivity" to a specific meaning. Within this meaning, the principle of objectivity is identified with a preventive and analytical self-limitation duty of the public administrations, through self-adhesion to assessment criteria and procedural frameworks established and published by the same administrations for the purpose of making subsequent decisions which do not fully adhere to the law. The principle of objectivity in itself can occupy an autonomous space within a broader circle represented by the principle of impartiality. The method in which the principle of objectivity reduces administrative partiality seems to consist of the "de-subjectivisation" of discretional assessments by the public administrations.
\end{abstract}

\section{Key words}

Objectivity, Impartiality, Neutrality, Transparency, Publicity, Integrity, Discretional nature 


\section{INTRODUCCIÓN: LA FALTA DE REFERENCIA TEXTUAL AL PRINCIPIO DE OBJETIVIDAD EN LA CONSTITUCIÓN ITALIANA Y EN LA LEY GENERAL SOBRE EL PROCEDIMIENTO ADMINISTRATIVO (L. 241/1990)}

De forma preliminar ${ }^{2}$ se debe destacar una diferencia relevante entre las experiencias jurídicas de España y de Italia.

La Constitución española consagra expresamente el principio de “objetividad" de la acción administrativa en el mismo artículo en el que luego se enuncia el principio de "imparcialidad" (art. 103).

No es así en la Constitución italiana: esta última, en el art. 97, establece el principio de "imparcialidad" administrativa, junto con el principio de "buena evolución", sin utilizar la locución diferente “objetividad” en relación con la organización y la acción de las administraciones públicas³.

2 Las sentencias jurisprudenciales citadas en el documento se pueden encontrar (a falta de indicaciones diferentes en las notas bibliográficas del pie de página) en los sitios www.giustizia-amministrativa.it, www.corteconti.it, www.cortecostituzionale.it o www.iuritalia.com. Las abreviaturas utilizadas son las siguientes:

Ad. plen. = Reunión Plenaria (Consejo de Estado); Arg. dir. lav. = Argomenti di diritto del lavoro (revista); $A a . V v_{.}$= autores varios; c.d. = así llamado/a; Cass. civ. = Casación Civil; Cons. Giust. Amm. = Consejo de Justicia Administrativa para la Región Siciliana; Cons. Estado = Consejo de Estado; Cons. Stato = Consiglio di Stato (revista); Tribunal Const. = Tribunal Constitucional; Const. = Constitución; Dig. disc. pubbl. = Digesto Discipline Pubblicistiche; Dir. amm. = Diritto amministrativo (revista); Dir. econ. = II diritto dell'economia (revista); Dir. e soc. = Diritto e società (revista); Dir. proc. amm. = Diritto processuale amministrativo (revista); Dir. e proc. amm. = Diritto e processo amministrativo (revista); Dir. pubbl. = Diritto pubblico (revista); Dir. reg. = Il diritto della Regione (revista); D.L. = decreto ley; D.Lgs. = decreto legislativo; D.M. = decreto ministerial; D.P.C.M. = decreto del Presidente del Consejo de ministros; Dir. P.C.M. = directiva del Presidente del Consejo de ministros; D.P.R. = decreto del Presidente de la República; Enc. dir. = Enciclopedia del diritto; Enc. giur. = Enciclopedia giuridica; Foro amm. $-C D S$ = II Foro amministrativo Consiglio di Stato (revista); Foro amm. $-T A R=$ II Foro amministrativo Tribunali amministrativi regionali (revista); Foro amm. = II Foro amministrativo (revista); Foro it. = II Foro italiano (revista); Inf. dir. = Informatica e diritto (revista); G.A. = juez administrativo; Giorn. dir. amm. = Giornale di diritto amministrativo (revista); Giur. cost. = Giurisprudenza costituzionale (revista); Giur. it. = Giurisprudenza italiana (revista); L. = ley; L.R. = ley regional; op. cit. = obra citada; Lav. pubbl. amm. = Il lavoro nelle pubbliche amministrazioni (revista); p.a. = administración pública; Quad. reg. = Quaderni regionali (revista); Ragiusan = Rassegna giuridica della sanità (revista); Rass. parl. = Rassegna parlamentare (revista); R.D. = real decreto; R.D.L. = Real decreto ley; Reg. = Reglamento; Riv. Corte Conti = Rivista della Corte dei Conti (revista); Riv. giur. lav. e prev. soc. = Rivista giuridica del lavoro e della previdenza sociale (revista); Riv. it. dir. lav. = Rivista italiana di diritto del lavoro (revista); Riv. it. dir. pubbl. com. = Rivista italiana di diritto pubblico comunitario (revista); Riv. trim. dir. proc. civ. = Rivista trimestrale di diritto e procedura civile (revista); Riv. trim. dir. pubbl. = Rivistra trimestrale di diritto pubblico (revista); Riv. trim. sc. amm. = Rivista trimestrale di scienza dell'amministrazione (revista); Sec. = Sección (de TAR o Consejo de Estado o Tribunal de Casación); Sec. jurisd. = Sección jurisdiccional (del Tribunal de Cuentas); Sec. Un. = Secciones Unidas (del Tribunal de Casación); TAR = Tribunal administrativo regional; T.U. = texto único; Urb. app. = Urbanistica e appalti (revista); vol. = volumen (de tratado o comentario).

3 A continuación se reproduce el texto del art. 97 Const.: "Los oficios públicos se organizan según disposiciones de ley de forma que se aseguren la buena evolución y la imparcialidad de la administración.

En el ordenamiento de los oficios se determinan las esferas de competencia, las atribuciones y las responsabilidades de los funcionarios.

A los empleos en las administraciones públicas se accede mediante concurso, salvo en los casos establecidos por la ley". 
Tampoco la ley general que regula en Italia el procedimiento administrativo, es decir, la L. 241/19904, menciona el principio de objetividad en la enunciación en el artículo 1 de los "principios generales de la actividad administrativa".

\section{RAZONES DE UNA INVESTIGACIÓN SOBRE EL PRINCIPIO DE OBJETIVIDAD EN EL DERECHO ADMINISTRATIVO ITALIANO: LA REFERENCIA EXPRESA A DICHO CANON POR PARTE DE LA LEGISLACIÓN Y DE LA JURISPRUDENCIA}

A pesar de la ausencia formal, en las dos principales fuentes reguladoras de los principios de la organización y de la acción administrativa (la Constitución y la L. 241/1990), de una referencia explícita a la "objetividad", no parece vano interrogarse, a título científico, sobre la existencia y la consistencia de un principio de esta índole en el ordenamiento italiano.

Para justificar el inicio de una investigación al respecto sería suficiente considerar un dato que surge del derecho de fuente legal y jurisprudencial.

Numerosos son los actos normativos (leyes estatales y regionales, reglamentos gubernamentales y ministeriales, etc.) y las sentencias jurisprudenciales (sentencias de jueces administrativos, algunas sentencias del Tribunal constitucional) en los que se hace referencia expresa y se nombra el principio (o canon, o criterio) de "objetividad" con respecto a la forma de ser y actuar de las administraciones públicas.

Un registro rápido (indicativo y somero, sin ninguna pretensión de exhaustividad) revela la referencia al principio de "objetividad" en varias disposiciones normativas que han regulado o que siguen regulando, por ejemplo: las modalidades de ejercicio de los poderes de algunas autoridades administrativas independientes (en especial, pero no solo, la Autoridad para las Garantías en las Comunicaciones $\mathrm{AGCOM}^{6}$ ); las modalidades de desarrollo de las valoraciones relacionadas con cursos

4 Titulada "Nuevas normas en materia de procedimiento administrativo y de derecho de acceso a los documentos administrativos".

5 A continuación se reproduce el texto vigente del art. 1 de la L. 241/1990 (modificado antes por la L. 15/2005 y después por la L. 69/2009): Art. 1. Principios generales de la actividad administrativa.

1. La actividad administrativa persigue los fines determinados por la ley y se rige por criterios de economicidad, eficacia, imparcialidad, publicidad y trasparencia, según las modalidades previstas por la presente ley y por las otras disposiciones que regulan cada procedimiento, así como por los principios del ordenamiento comunitario.

1-bis. La administración pública, en la adopción de actos de naturaleza no autoritativa, actúa según las normas de derecho privado, salvo que la ley disponga lo contrario.

1-ter. Los sujetos privados encargados del ejercicio de actividades administrativas aseguran el cumplimiento de los principios indicados en el párrafo 1.

2. La administración pública no puede agravar el procedimiento si no es por exigencias extraordinarias y motivadas impuestas por el desarrollo de la instrucción".

6 Las referencias normativas, en relación con el AGCOM, son numerosas. Baste con citar para todas el D.Lgs. 259/2003 (Código de las comunicaciones electrónicas), art. 15, párrafo 2 (“La Autoridad establece el plan nacional de numeración y los procedimientos de asignación de la numeración en cumpli- 


\section{o concursos públicos o ascensos de carrera de funcionarios públicos; los procedi- mientos administrativos para la aplicación, en materia de emisión radiotelevisiva, de}

miento de los principios de objetividad, trasparencia y no discriminación, de modo que se garantice igualdad de trato a todos los proveedores de servicios de comunicación electrónica accesibles al público ") y art. 53, párrafo 2 ("La Autoridad determina el método más eficaz y adecuado para garantizar la prestación del servicio universal a un precio accesible, en cumplimiento de los principios de objetividad, trasparencia, no discriminación y proporcionalidad. La Autoridad limita las distorsiones del mercado, en especial la prestación de servicios a precios u otras condiciones diferentes de las normales condiciones comerciales, tutelando al mismo tiempo el interés público"). Significativa es también la "Guía para la actividad de Vigilancia" de la Circular de la Banca d'Italia n. ${ }^{\circ} 269$ del 7 de mayo de 2008: allí, en la Parte Tercera, relacionada con los “Procedimientos de inspección”, en la Sección I, párrafo I.5, se afirma que “los principios de objetividad y trasparencia constituyen valores de referencia en el ejercicio de la actividad de supervisión bancaria y financiera" por parte de la Banca d'Italia, y se añade que "en la aplicación concreta del principio de objetividad, es oportuno distinguir entre hechos y valoraciones. De los primeros se debe sopesar la relevancia, a la luz -además del marco normativo general- de las finalidades de la comprobación, de la operatividad del intermediario, del contexto que resulta de la verificación. En cuanto a las valoraciones, subjetivas por su naturaleza, es preciso minimizar el riesgo de divergencia de juicio, que aumenta típicamente en la apreciación de fenómenos de naturaleza cualitativa... La Guía tiende a atenuar dicho riesgo, previendo parámetros estándar. Sin embargo, la realidad observada podría alejarse de la que presuponen los parámetros. En situaciones de este tipo, el encargado se ocupa de adaptar los criterios de análisis al caso concreto, también a la luz de las modalidades de tratamiento de casos análogos...".

7 En línea generales, véase el D.Lgs. 165/2001 (Normas generales sobre el ordenamiento del trabajo dependiente de las administraciones públicas), art. 35, párrafo 3 ("Los procedimientos de contratación en las administraciones públicas se rigen por los principios siguientes: a) publicidad adecuada de la selección y modalidad de desarrollo que garanticen la imparcialidad y aseguren economicidad y rapidez de ejecución, recurriendo, donde fuera oportuno, al apoyo de sistemas automatizados, destinados también a realizar formas de preselección; b) adopción de mecanismos objetivos y trasparentes aptos para verificar que se poseen los requisitos de aptitudes y los profesionales requeridos en relación con el puesto a cubrir; c) respeto de la igualdad de oportunidades entre trabajadoras y trabajadores; d) descentralización de los procedimiento de contratación; e) composición de las comisiones exclusivamente con expertos de probada competencia en las materias de concurso, seleccionados entre funcionarios de las administraciones, docentes y personas ajenas a las mismas, que no pertenezcan al órgano de dirección política de la administración, que no cubran cargos políticos y que no sean representantes sindicales o estén nombrados por las confederaciones y organizaciones sindicales o por las asociaciones profesionales"), y art. 53, párrafos 2 y 5 ("Las administraciones públicas no pueden asignar a los empleados tareas no incluidas en los cometidos y deberes de oficio, que no estén expresamente previstos o regulados por ley u otras fuentes normativas, o que no estén expresamente autorizados... En cualquier caso, la asignación realizada directamente por la administración, así como la autorización para el ejercicio de encargos procedentes de una administración pública diferente de la de pertenencia, es decir, por sociedades o personas físicas que desempeñen actividades empresariales o comerciales, están regulados por los órganos competentes correspondientes según criterios objetivos y predeterminados que tengan en cuenta la profesionalidad específica, tales que excluyan casos de incompatibilidad, tanto de derecho como de hecho, en el interés de la buena marcha de la administración pública”). Para aplicaciones específicas véase el D.M. 94/2004 (Reglamento concerniente las modalidades de desarrollo de los cursos de formación para el acceso a los puestos normal, aeronaval, especial y técnico-logístico-administrativo de los oficiales de la Guardia di Finanza, incluidos los de formación de las graduaciones, así como las causas y los procedimientos de remisión y expulsión), art. 18: “Las modalidades de comprobación del aprovechamiento en los estudios tienen lugar en condiciones que garantizan la profundización, la objetividad y la equidad de la valoración en relación con la disciplina seguida y con lo que los programas de examen requieren explícitamente". Siempre a título de ejemplo, véase también el D.M. 5/2002 (Normas para la institución, la organización y el funcionamiento de la Comisión para el progreso de carrera del personal perteneciente al estamento de directivos y altos cargos de la Policía de Estado), art. 4: “La Comisión establece cada trienio, según las exigencias de cada cargo del personal de la Policía del Estado, los criterios de valoración para los escrutinios... En la identificación de los criterios, la Comisión tiene en cuenta las categorías de los títulos admitidos en la valoración, desde el arco temporal 
las medidas de habilitación, autorización y concesión necesarias para el acceso a las frecuencias y para la instalación de redes y equipos ${ }^{8}$; la imposición de limitaciones administrativas en el régimen de autoasistencia en el ámbito aeroportuario9; los procedimientos administrativos para la concesión de la licencias que habilitan para la oferta al público de servicios postales no reservados ${ }^{10}$; las relaciones entre superiores

de referencia y de los coeficientes numéricos correspondientes... La comisión define parámetros aptos para permitir una valoración responsable de las cualidades profesionales de los funcionarios, sobre todo en vista de la atribución de la calificación superior, y a garantizar la objetividad necesaria en la valoración completa de la personalidad del candidato para que se admita a escrutinio". Véase también el D.Lgs. 139/2000 (Disposiciones en materia de relación laboral del personal de la carrera para Gobernador Civil, según el artículo 10 de la ley n. ${ }^{\circ} 266$ del 28 de julio de 1999,), art. 8 ("Valoración comparativa"), párrafo 2: "El consejo de administración, bajo propuesta del jefe del departamento competente para la administración del personal de la carrera para Gobernador Civil, determina, con cadencia trienal, los criterios para la atribución de las puntuaciones en las fichas de valoración según el artículo 16 y en las categorías de los títulos de servicio de forma que se garantice la máxima objetividad en la valoración ". Siempre a título de ejemplo, a escala regional véase la L.R. Lacio 41/1990, art. 38: "A los altos cargos les corresponde una indemnización de función vinculada al ejercicio efectivo de las funciones ... Cada administración destinataria de las normas de la presente ley, con las medidas previstas en los ordenamientos correspondientes, determina de forma preventiva los parámetros de referencia y los criterios necesarios para la identificación de los coeficientes de la indemnización que se ha de atribuir a las diversas funciones garantizando objectividad y la trasparencia en los comportamientos de actuación" (idéntico es el texto de las leyes regionales coetáneas como la L.R. Calabria 30/1990, art. 37 o la L.R. Liguria 15/1990, art. 37).

8 D.Lgs. 177/2005 (Texto Único de la Radiotelevisione), art. 12, párrafo 1, letra b): “Las regiones ejercen la potestad legislativa concurrente en materia de emisión radiotelevisiva en el ámbito regional o provincial, en cumplimiento de los principios fundamentales contenidos en el título I y sobre la base de los siguientes principios fundamentales ulteriores ... atribución a órganos de la región o de las entidades locales de las competencia en relación con la emisión de medidas de habilitación, autorización y concesión necesarias para el acceso a los sitios previstos por el plan nacional de asignación de las frecuencias, sobre la base de las disposiciones nacionales y regionales vigentes, para la instalación de redes y equipos, en cumplimiento de los principios de no discriminación, proporcionalidad y objetividad".

9 D.Lgs. 18/1999 (Aplicación de la directiva 96/67/CE relativa al libre acceso al mercado de servicios de asistencia en tierra en los aeropuertos de la Comunidad), art. 5, párrafos 2 y 3: "En los aeropuertos con tráfico anual igual o superior a 1 millón de pasajeros o a 25 mil toneladas de mercancía, la Entidad Nacional para la Aviación Civil (ENAC), en cumplimiento de los criterios de objetividad, trasparencia y no discriminación, a petición de la entidad de gestión puede limitar, por razones motivadas relacionadas con la seguridad, a la capacidad o al espacio disponible en el aeropuerto el número de sujetos autorizados para la autoasistencia en las categorías de servicios de asistencia de equipaje, la asistencia de operaciones en la pista, la asistencia de carburante, la asistencia de mercancías y correo en lo relacionado con el tratamiento físico de las mercancías y del correo por llegar, por salir y en tránsito entre el aeropuerto y el aeromóvil, garantizando su realización por parte de al menos dos solicitantes. En los aeropuertos con tráfico anual inferior a un millón de pasajeros o a 25 mil toneladas de mercancías, el ENAC puede excluir, en cumplimiento de los criterios y según las modalidades establecidas en el párrafo 2 del régimen de autoasistencia, los servicios indicados en el mismo párrafo $2 "$.

10 D.Lgs. 261/1999 (Aplicación de la directiva 97/67/CE concerniente a normas comunes para el desarrollo del mercado interno de los servicios de correo comunitarios y para la mejora de la calidad del servicio), art. 5: "La oferta al público de cada servicio no reservado que pertenezca al ámbito de aplicación del servicio universal está sujeta a la concesión de licencia individual por parte del Ministerio de Desarrollo Económico... Con la medida de la autoridad de reglamentación, que ha de emitirse dentro de noventa días desde la fecha de entrada en vigor del presente decreto, se determinan los requisitos para la concesión de las licencias individuales, las obligaciones por cuenta de los titulares de las propias licencias, las modalidades de los controles en las sedes de las actividades y, en caso de incumplimiento de las obligaciones, los procedimientos de requerimiento, así como de suspensión y revocación de la licencia individual. Las dispo- 
y subordinados en la organización jerárquica de la ordenación militar ${ }^{11}$; los procedimientos con los que las Empresas Sanitarias Locales controlan el cumplimiento del horario de servicio por parte de profesionales allí empleados ${ }^{12}$; la organización y las funciones de entidades públicas (como el Instituto Nacional de Estadística - ISTAT ${ }^{13}$ o el Instituto Nacional de Investigación Metrológica - INRIM ${ }^{14}$ ); las normas generales para el desarrollo de las inspecciones administrativas ${ }^{15}$; los principios que regulan la

siciones indicadas en el antedicho reglamento garantizan el cumplimiento de los principios de objetividad, no discriminación, proporcionalidad y trasparencia".

11 Véase el D.P.R. 90/2010 (Texto único de las disposiciones reglamentarias en materia de ordenamiento militar, según el artículo 14 de la ley n. ${ }^{\circ} 246$ del 28 de noviembre de 2005), art. 725 ("Deberes propios de los superiores"), párrafo 2: "El superior debe mantener firme la disciplina de los militares empleados e intentar conseguir la máxima eficiencia de la unidad, entidad u oficina a su cargo. En especial, él debe... respetar la igual dignidad de todos en las relaciones con los subordinados y someter siempre sus valoraciones a criterios de objetividad y justicia".

12 D.P.R. 446/2001 ("Reglamento para la aplicación del acuerdo colectivo nacional para la disciplina de las relaciones con los biólogos, químicos y sicólogos de centros médicos, del 1998-2000"), art. 10, párrafo 2: "La Empresa Sanitaria se encarga de controlar el cumplimiento del horario mediante procedimientos de plena objetividad ... que permitan conocer la hora de entrada y salida del servicio del profesional").

13 D.P.R. 166/2010, art. 2: “El ISTAT - Instituto nacional de estadística, entidad pública dotada de autonomía científica, organizativa, financiera y contable, desarrolla su actividad según los principios de independencia científica, imparcialidad, objetividad, fiabilidad, calidad y confidencialidad de la información estadística dictados a escala europea e internacional”.

14 Reg. del 18 de marzo de 2005, art. 20: "La organización y el funcionamiento del servicio de acreditación de laboratorios se definen con modalidades tales que salvaguarden la privacidad, la objetividad y la imparcialidad de las actividades de acreditación y que excluyan conflictos de interés con las actividades de calibración y prueba desempeñadas en el ámbito del departamento".

15 Dir. P.C.M. del 2 de julio de 2002 (Actividades de inspección), en donde se establece: "Las normas propuestas en esta Directiva son: A) todas las iniciativas del inspector se deben basar en la imparcialidad y autonomía de juicio. La actividad de inspección presupone la imparcialidad y la autonomía de juicio. La función de sujeto ajeno y neutral (imparcialidad de tercero), que debe caracterizar la actividad del inspector, le permite presentar propuestas para resolver las ineficiencias que encuentra; mientras que la autonomía de juicio califica la profesionalidad y garantiza la imparcialidad que debe caracterizar el trabajo de cualquier empleado de la administración pública ... B) la formación, la profesionalidad y la competencia ... C) el conocimiento y el análisis de la actividad y la normativa de la entidad o de la oficina sometida a inspección ... D) la inspección en su conjunto está cubierta por una rigurosa confidencialidad ... E) el inspector es firme, pero está disponible. Este comportamiento debe estar siempre orientado hacia la solución de los problemas surgidos ... F) la objetividad metodológica ... procediendo con método basado en elementos probatorios tales que permitan compartir las observaciones expuestas, el inspector puede mostrar la objetividad de sus comprobaciones, el valor significativo de las propuestas y la relevancia de los resultados. Solo la validez de la metodología de investigación aporta, en el ámbito de la oficina inspeccionada, una contribución que se concreta en una administración más fuerte en relación con las decisiones y más eficaz en los servicios prestados ... G) el inspector perturbará lo menos posible el funcionamiento regular de la estructura inspeccionada ... H) las observaciones y los informes se basarán en elementos probatorios y circunstanciados ... esta norma difiere de la anterior del punto $\mathrm{F}$ ... se refiere a los hechos que dan objetividad a los elementos probatorios, no al método seguido en la investigación ... I) la inspección será demostrable en cada uno de sus actos. Las actas, los informes, los extractos de la documentación y cualquier otro elemento útil garantizarán esta condición. La inspección, además de ser objetiva tanto en cuanto al método como a los elementos probatorios, se demostrará y documentará en cada una de sus partes por las problemáticas encontradas en los resultados finales ... L) Los resultados de la inspección se comunicarán al sujeto o a la estructura inspeccionada ... La comunicación de los resultados de la inspección da valor añadido a la buena marcha de la administración pública, y cumple los principios enunciados en el código de comportamiento de los empleados de las administraciones públicas. Además, el hecho de comunicar los resultados de una inspección llevada a cabo en cumplimiento de las normas descritas en esta Directiva, contribuye a difundir la trasparencia de las actividades de la administración pública". 
prestación de los servicios públicos ${ }^{16}$; los criterios para el destino de la publicidad, las informaciones y las campañas promocionales de administraciones públicas ${ }^{17}$; las mo-

16 Al menos a partir de la Dir. P.C.M. del 27 de enero de 1994 (Principios sobre la prestación de los servicios públicos), en la que se enuncian los siguientes "Principios fundamentales" para la prestación de los servicios públicos:

“1. IGUALDAD. La prestación del servicio público se debe inspirar en el principio de igualdad de derechos de los usuarios. Las normas inherentes a las relaciones entre usuarios y servicios públicos y el acceso a los servicios públicos deben ser iguales para todos. No se puede hacer ninguna distinción en cuanto a la prestación del servicio por motivos relacionados con sexo, raza, idioma, religión u opiniones políticas. Hay que garantizar la igualdad de trato, en igualdad de condiciones del servicio prestado, tanto entre las diversas áreas geográficas de los usuarios, incluso sin fácil acceso, como entre las diversas categorías o grupos de usuarios. La igualdad ha de entenderse como la prohibición de cualquier discriminación injustificada y no como uniformidad de las prestaciones bajo el perfil de las condiciones personales y sociales. En especial, los sujetos que prestan el servicio están obligados a adoptar las iniciativas necesarias para adaptar las modalidades de prestación del servicio a las exigencias de los usuarios que sufran minusvalías.

2. IMPARCIALIDAD. Los sujetos prestadores de servicios tienen la obligación de inspirar sus comportamientos, de cara a los usuarios, en criterios de objetividad, justicia e imparcialidad. En función de dicha obligación se interpreta cada cláusula de las condiciones generales y específicas de prestación del servicio y las normas reguladoras de sector.

3. CONTINUIDAD. La prestación de los servicios públicos, en el ámbito de las modalidades establecidas por la normativa reguladora de sector, debe ser continua, regular y sin interrupciones. Los casos de funcionamiento irregular o de interrupción del servicio deben ser regulados expresamente por la normativa de sector. En dichos casos, los sujetos prestadores de servicios deben adoptar medidas que causen la menor molestia posible a los usuarios.

4. DERECHO DE ELECCIÓN. En los casos en que la legislación vigente lo permita, el usuario tiene derecho a elegir entre los sujetos que prestan el servicio. El derecho de elección se refiere, en especial, a los servicios distribuidos en el territorio.

5. PARTICIPACIÓN. La participación del ciudadano en la prestación del servicio público se debe garantizar siempre, tanto para tutelar el derecho a la prestación correcta del servicio, como para favorecer la colaboración con los sujetos que lo prestan. El usuario tiene derecho de acceso a las informaciones que sobre él están en poder del sujeto prestador del servicio. El derecho de acceso se ejerce según las modalidades establecidas en la ley . $^{\circ} 241$ del 7 de agosto de 1990. El usuario puede producir memorias y documentos, exponer observaciones y formular sugerencias para la mejora del servicio. Los sujetos que prestan el servicio responden de inmediato al usuario sobre las observaciones y propuestas que éste formule. Los sujetos que prestan el servicio obtienen periódicamente la valoración del usuario sobre la calidad del servicio prestado, según las modalidades indicadas en el título siguiente.

6. EFICIENCIA Y EFICACIA. El servicio público se debe prestar de forma que garantice la eficiencia y la eficacia. Los sujetos que lo prestan aplican las mediadas idóneas para alcanzar dichos objetivos".

Véase también, para la enunciación del principio de objetividad en la prestación de los servicios públicos, entre las numerosas actas, el D.P.C.M. del 21 de diciembre de 1995 (Esquema general de referencia para la predisposición de los reglamentos de los servicios públicos del sector de la seguridad social), según el cual "Ios sujetos que prestan el servicio actúan bajo criterios de objetividad, justicia e imparcialidad”, o el D.P.C.M. del 7 de junio de 1995 (Esquema general de referencia de los reglamentos de los servicios escolares), según el cual "los sujetos que prestan el servicio escolar actúan bajo criterios de objetividad y equidad".

17 L. 416/1981 (Disciplina de las empresas editoriales y ayudas para el sector editorial), art. 13 (Publicidad de administraciones públicas), párrafos 3 y 4: “La Presidencia del Consejo de Ministros emite, comunicándolas al Garante, las directrices generales a las administraciones estatales para que la ayuda a la publicidad, las informaciones y las campañas promocionales se distribuya sin discriminaciones y con criterios de equidad, objetividad y economía. La Presidencia del Consejo de Ministros establece criterios para la publicidad destinada a la información sobre las leyes y su aplicación, así como sobre los servicios, las estructuras y su utilización, procurando que el reparto de dicha publicidad tenga en cuenta las cabeceras que por su naturaleza alcanzan a los usuarios que estén específicamente interesados en dichas leyes, como los 312 femeninos, juveniles y del mundo del trabajo". 
dalidades de desempeño de las actividades desarrolladas por sujetos probados encargados de funciones públicas (como, por ejemplo, el Gestor del Mercado Eléctrico [actualmente denominado Gestor de los Mercados Energéticos] - GME, o la Entidad Italiana de Acreditación ACCREDIA) ${ }^{18}$, et similia.

La referencia al principio de "objetividad" está presente también en muchas sentencias de los órganos de justicia administrativa y de la magistratura contable, sobre todo en materia de valoraciones expresadas en concursos públicos, en selecciones para el acceso a empleos públicos, en procedimientos para el progreso de carrera o para la confirmación en el cargo público ${ }^{19}$, en procedimientos de concurso relacionados

18 Al GME se le ha asignado ex lege la tarea de organizar y gestionar el nuevo mercado eléctrico tras su liberalización, activada por el D.lgs. 79/1999. Después, la L. 99/2009 ha confiado en exclusiva al GME también la gestión económica del mercado del gas natural. El GME es una sociedad anónima "legal” (dado que su constitución ha sido impuesta de forma obligatoria por la ley), a la que se han otorgado funciones publicistas y está controlada en su totalidad por otra sociedad anónima "legal" (es decir, el Gestor de Servicios Eléctricos [actualmente denominado Gestor de Servicios Energéticos] - GSE), cuyo accionista único es el Estado italiano (Ministerio de Economía). Con respecto al GME, el D.lgs. 79/1999 (Aplicación de la directiva 96/92/CE sobre normas comunes para el mercado interior de la energía eléctrica), en el art. 5, párrafo 1, establece que "la gestión económica del mercado eléctrico se asigna a un gestor del mercado. El gestor del mercado es una sociedad anónima, constituida por el gestor de la red de trasmisión nacional en los nueve meses siguientes a la fecha de entrada en vigor del presente decreto. Éste organiza el propio mercado según criterios de neutralidad, trasparencia y objetividad, así como de competencia entre productores, garantizando, además, la gestión económica de una disponibilidad adecuada de la reserva de potencia. La regulación del mercado, marcada por el gestor del mercado en el año siguiente a la fecha se su constitución, está aprobada por decreto del Ministro de industria, comercio y artesanía, tras consultar a la Autoridad para la energía eléctrica y el gas. En especial, en cumplimiento de los antedichos criterios, prevé las tareas del gestor del mercado...”. Posteriormente, la L. 99/2009 (Disposiciones sobre el desarrollo y la internacionalización de las empresas, así como en materia de energía), en el art. 30, párrafo 1, ha establecido que "la gestión económica del mercado del gas natural se ha asignado en exclusiva al Gestor del Mercado Eléctrico según el artículo 5 del decreto legislativo n. ${ }^{\circ} 79$ del 16 de marzo de 1999. El Gestor organiza el mercado del gas natural según criterios de neutralidad, trasparencia, objetividad y competencia”.

ACCREDIA es una Asociación sin ánimo de lucro, dotada de personalidad jurídica, de derecho privado (de la que son socios muchos ministerios, entidades públicas y asociaciones sectoriales), la cual ha sido nombrada como único organismo nacional italiano de acreditación para el desempeño de funciones de acreditación y vigilancia del mercado en relación con la comercialización de los productos según el reglamento (CE) n. ${ }^{0}$ 765/2008. Según el art. 4 de la L. 99/2009, el único organismo nacional italiano de acreditación actúa bajo el control y la vigilancia del Estado. El D.M. del 22 de diciembre de 2009 (Prescripciones sobre la organización y el funcionamiento del único organismo nacional italiano autorizado para el desempeño de actividades de acreditación según el reglamento CE n. ${ }^{\circ} 765 / 2008$ ), establece, en el art. 3, que "el organismo nacional italiano de acreditación se adapta a los principios y prescripciones siguientes ... está dotado de un modelo organizativo cuyo fin es garantizar que la acreditación, independientemente de la utilización obligatoria o voluntaria prevista, se realiza como actividad de interés público “; en el siguiente art. 4, establece que "el organismo nacional italiano de acreditación está dotado de personalidad jurídica, de estatutos, de una estructura organizativa y de instrumentos de gestión para... salvaguardar la objetividad y la imparcialidad de su propia actividad".

19 Solo como ejemplos, considérense las sentencias siguientes. TAR Puglia-Bari, Sec. I, 23 de abril 2003, n. ${ }^{\circ}$ 1780: "el tribunal juzga la valoración comparativa entre los diversos candidatos según normas de objetividad absoluta y trasparencia, evitando la constitución previa de recorridos preferentes a favor de algunos candidatos por razones que no tengan nada que ver con el mérito, dado que en cumplimiento de dichas normas siempre es posible provocar la aprobación del juez de la legitimidad”. TAR Sardegna, 26 de enero de 2004, n. ${ }^{\circ}$ 78: "Por lo tanto se puede afirmar que la materia universitaria, en relación con las mo- 
dalidades de contratación, está regulada de forma exhaustiva por una normativa sectorial específica. También es verdad que esta especificidad no impide que se puedan aplicar normas generales de los concursos públicos cuando contengan prescripciones que tiendan a garantizar objetividad y la imparcialidad en el procedimiento concursal, que, por su propia inderogabilidad absoluta, asumen valor de principios generales". TAR Sicilia-Catania, Sec. III, 14 de junio de 2004, n.`1637: "es evidente que solo la predeterminación de los criterios con los que se establecerán los coeficientes de indemnización para las varias funciones, es capaz de garantizar objetividad e imparcialidad a la acción administrativa; viceversa, los criterios determinados según situaciones personales ya conocidas podrían llevar a la aplicación de coeficientes de indemnización confeccionados ad hoc". TAR Umbria, 29 de noviembre de 2005, n. 662 : "Como norma, por tanto, con el debido respeto a los bien conocidos principios de imparcialidad, objetividad y trasparencia de la acción administrativa, en los casos en los que por auto judicial explícito haga falta renovar un juicio de valoración delicado como el del caso en cuestión, del mismo modo se debe considerar oportuna y también necesaria la reconstitución de la comisión con componentes totalmente diferentes de los anteriores. La oportunidad y la necesidad jurídica de dicha reconstitución parecen, en general, totalmente evidentes no solo considerando el citado compromiso (natural) objetivo de la serenidad de juicio de los comisarios anteriores (en el supuesto ya considerados, con sentencia, no perfectamente cumplidores de las funciones de valoración comparativa que se les habían encomendado), sino también considerando la más general necesidad (ésta también ineludible) de que el nuevo comportamiento de valoración de la Administración Pública se depure, en casos de esta índole, de cualquier tipo de duda de ilegitimidad, en primer lugar la relacionada con la posible y/o probable reiteración (acrítica y/o pasiva) de las valoraciones personales ya expresadas con anterioridad. Sustancialmente se trata del cumplimiento de normas sobre imparcialidad y objetividad de los juicios de valoración que tengan que inspirar correctamente los procedimientos de nuevo examen y/o revisión para que la acción administrativa sea plenamente trasparente en la tutela de los intereses legítimos de los sujetos administrados". Cons. Estado, Sec. V, 19 de septiembre de 2006, n. ${ }^{\circ} 5476$ : "Asimismo, se recoge en la jurisprudencia, porque es una consecuencia lógica por demás generalmente aceptada, el hecho de que un juicio puede responder en primer lugar a la objetividad, dado que se expresa sobre la base de comparaciones con medias predeterminadas... la ausencia de prefijación de elementos homogéneos de valoración de los resultados de gestión recogidos y, finalmente, el carácter genérico o las otras imprecisiones arriba descritas de algunas observaciones expresadas, llevan a compartir el juicio, dado por el primer juez, sobre la ilegitimidad de la resolución impugnada". Cons. Estado, sec. VI, 16 de febrero de 2007, n. ${ }^{\circ} 659$ : "la constatación en el ámbito jurisdiccional de vicios de procedimiento o de exceso de poder que invaliden los procedimientos principales expresados por el órgano responsable de las operaciones de valoración comparativa de los candidatos para cubrir el puesto en concurso, no determina una situación de incompatibilidad de los componentes del colegio cuando haya que proceder a la renovación del juicio objeto de anulación con enmienda de los vicios comprobados en el momento del resultado del contencioso. Los principios de imparcialidad y objetividad de los juicios no reciben "vulnus" por el mero elemento formal de que la composición del colegio sea idéntica". TAR Lazio, Sec. I-quater, 5 de octubre de 2006, n.` 9937: “Como también afirmó expresamente en el pasado el Consejo de Estado, el establecimiento de criterios de valoración de las pruebas de examen llevado a cabo tras la realización de las mismas, pero antes del juicio correspondiente, no se puede considerar contrario a los principios de objetividad e imparcialidad en la valoración de las propias pruebas". TAR Campania-Salerno, Sec. II, 21 de junio de 2008, n. ${ }^{\circ} 1991:$ "la predeterminación de criterios que se ha producido... representa un pasaje necesario para garantizar la objetividad y la trasparencia de la actuación de la comisión para un concurso por títulos y exámenes". Cons. Estado, Sec. IV, 31de marzo de 2009, n.․ 2006: "el desglose de los términos de valoración indicados en el reglamento general por la comisión... responde a la exigencia primaria de hacer que los criterios de valoración sean conformes con los principios de objetividad, imparcialidad y trasparencia de las operaciones concursales (véase, hoy, el art. 35, párrafo 3, d.lgs. n. ${ }^{\circ} 165 / 2001$ )". Tribunal de Cuentas, Lombardia, Sec. Jurisd., 20 de octubre de 2009, n. ${ }^{\circ}$ 642: "es preciso hacer referencia al art. 7, párrafo 6-bis, d.Igs. n. ${ }^{\circ} 165 / 2001$, que obliga a las administraciones a regular y hacer públicos, según sus ordenamientos, procedimientos comparativos para el otorgamiento de encargos de colaboración. Con dicha disposición se ha pretendido expresamente poner fin a la praxis del otorgamiento de encargos ad personam, en detrimento de los principios de publicidad, trasparencia y objetividad de los mecanismos de contratación, que, a pesar de estar citados en el art. 35 d.lgs. n. ${ }^{\circ}$ 165/2001 en relación con la contratación por concurso (en aplicación directa de lo dispuesto en el art. 97 Const.), se deben poder referir generalmente a todos los 
con la adjudicación de contratas públicas o de concesiones ${ }^{20}$; sin embargo, a veces se encuentra también en sentencias que tienen un objeto diferente, por ejemplo en materia de establecimiento de nuevas sedes farmacéuticas ${ }^{21}$, de fijación de los precios de los fárma $\cos ^{22}$, de aprobación del plan para las canteras ${ }^{23}$, de ejercicio del poder reglamentario por parte de los Municipios en relación con la localización de las instalaciones de

la Constitución; de allí se deduce que lo relevante es, para los candidatos, la exactitud de las respuestas a las preguntas propuestas, mientras que es competencia de la administración establecer la forma de valoración de las pruebas, con objeto de asegurar la objetividad y la trasparencia del juicio, además de la par condicio entre candidatos. Objetividad, trasparencia e igualdad de trato que el criterio de valoración arriba indicado no ha puesto en peligro de ningún modo".

20 TAR Umbria, Sec. I, 1 de febrero de 2000, n. ${ }^{\circ} 46:$ "Cuando una normativa de concurso atribuye a la comisión un amplio poder discrecional, como es el relacionado con la identificación del suministro "análogo", la Comisión misma, en cumplimiento de los principios de la par condicio y de la trasparencia y objetividad de los concursos (art. 97 Const.), debe establecer los criterios que se han de aplicar al empleo de ese poder “. Cons. Estado, Sec. V, 19 de febrero de 2003, n. ${ }^{\circ}$ 908: "ha habido... una modificación de los criterios de valoración... se trata... de una elección llevada a cabo en un momento en que la Comisión conocía las ofertas en todos sus aspectos, por lo que la modificación así aplicada... llega a chocar con los cánones de la trasparencia y objetividad de la acción administrativa y con el principio de la par condicio entre los concursantes". TAR Lacio-Latina, 26 de abril de 2004, n. ${ }^{\circ} 232$ : “El criterio de la separación entre la oferta técnica y la oferta económica y estas de la documentación administrativa... en los procedimientos de concurso público representa un límite insuperable. Esto como garantía de la exigencia de objetividad y de imparcialidad". TAR Campania, Sec. II, 24 de marzo de 2006, n. ${ }^{\circ} 3177$ : “La mera presencia en una fase marcada por la garantía férrea del anonimato incluso de un solo documentos destinado a desvelar el autor del proyecto habría invalidado irremediablemente todo el juicio, prejuzgando la actitud para mostrarse al exterior como expresión cierta e indiscutida de objetividad y de imparcialidad”. TAR Lazio, Sec. III-quater, 2 de octubre de 2008, n. ${ }^{\circ}$ 9057: "Esto está demostrado directamente por la propia indeterminación del criterio de valoración de las referencias, que carece totalmente de cualquier elemento capaz de hacer comprender al concursante sobre qué bases se habría dado cabida a la asignación de puntuaciones. Por lo tanto, es evidente la violación de los principios de objetividad y de trasparencia". Cons. Estado, Sec. V, 15 de marzo de 2010, n. ${ }^{\circ}$ 1507: "La observación se apoya, por si acaso fuera necesario, en el método de valoración elegido: es decir, la comparación por parejas. En concreto, la Comisión examinadora ha adoptado el método: con respecto a él, la identificación de modalidades, lugares y costes constituye una predeterminación indispensable de los criterios de valoración... dicho método... es capaz de dar iguales garantías de objetividad e imparcialidad que los otros utilizados para la valoración de ofertas”.

21 Cons. Estado, Sec. IV, 15 de noviembre de 2004, n. ${ }^{\circ} 7429$ : “Es indiscutible que la afirmación de la administración regional de subsistencia, en el caso que nos ocupa, de los supuestos de hecho que legitiman la institución de la nueva sede farmacéutica es fruto de una valoración absolutamente parcial y personal de los propios hechos, privada de la objetividad necesaria en la que siempre se debe inspirar la acción administrativa (respetando los principios fundamentales sancionados por el artículo 97 de la Constitución)".

22 TAR Lazio, Sec. III-ter, 6 de octubre de 2003, n. 8043: “No se encuentra... ninguna violación del principio de trasparencia ni de objetividad y verificabilidad en la fijación de los precios de los fármacos, porque el DM impugnado plantea con extremada claridad y puntualidad los criterios utilizados, y permite recorrer el razonamiento lógico seguido para la fijación del precio".

23 TAR Lombardía-Milán, Sec. IV, 11 de noviembre de 2009, n. 5015: "Ante los resultados de la instrucción realizada por las oficinas técnicas regionales, la Comisión Asesora primero y el Consejo Regional después han cancelado completamente la propuesta de la Junta, pero sin desarrollar ninguna consideración de orden técnico sobre la propuesta de la propia Junta, que así parece haber sido desatendida por meras razones de orden político, que sin embargo no son pertinentes porque el órgano asesor debe proceder a la discusión y a la aprobación del Plan de Canales... el Consejo Regional, encargado de la aprobación del plan provincial de canales según lo establecido por la ley regional 14/1998, desempeña una función de carácter administrativo sujeta a los deberes de imparcialidad y objetividad propios de la acción administrativa ...". En el mismo sentido TAR Lombardía-Milán, Sec. IV, 3 de febrero de 2011, n. ${ }^{\circ} 344$. 
telefonía móvil ${ }^{24}$, de establecimiento de una sede separada de un Municipio en el territorio de otro Municipio ${ }^{25}$, de nombramiento ministerial de los miembros de la Comisión para la igualdad de oportunidades según el D. Lgs. $226 / 2003^{26}$, etc.

También el Tribunal constitucional, en algunas sentencias, ha hecho referencia al canon de la "objetividad" de la acción administrativa²7.

A la luz de estos elementos sintomáticos, es innegable que, también en Italia, el magma del derecho vivo de las administraciones públicas hace aflorar el paradigma de la "objetividad", situándolo en el centro de la investigación.

24 TAR Puglia-Lecce, Sec. II, 14 de febrero de 2007, n. 1061: “La vía maestra que deben recorrer los Municipios no puede ser otra que la de la profundización científico-técnica, en función no ya de la determinación de los valores de campo distintos de los establecidos por la normativa estatal y de medidas que subrepticiamente afecten a los valores de campo, sino siempre en la disciplina del correcto asentamiento urbanístico y territorial de las instalaciones en función del objetivo de minimizar la exposición a los campos electromagnéticos. En sustancia, se trata de aplicar también a esta materia los principios que la jurisprudencia ha elaborado a propósito de los instrumentos urbanísticos... los cuales, limitando el contenido del derecho de propiedad... y al no encontrar ninguna disposición de ley, las directrices de información... encuentran la justificación de su propia existencia en la objetividad y la racionalidad de la disciplina dictada".

25 Tribunal de Cuentas, Sicilia, Sec. jurisd., 15 de octubre de 2010, n. ${ }^{\circ} 2152$ : "Al Tribunal, con objeto de no sobrepasar los límites extremos de su poder jurisdiccional violando la llamada "reserva de administración", no le está permitido censurar y valorar la oportunidad ni la conveniencia administrativa de las elecciones hechas y, por lo tanto, de las razones por las que la autoridad pública haya escogido una opción en lugar de otra y/o haya adoptado una solución en lugar de otra para perseguir sus propios fines institucionales, estando prohibida cualquier injerencia en la actividad de ponderación comparada de los intereses. Sin embargo, una vez realizada la elección no se le puede negar al juez contable que se informe posteriormente sobre el momento volitivo y que proceda a una valoración de la actuación de la administración en cuanto a legitimidad, según las reglas llamadas internas de la actuación administrativa previstas también por el art. 1 de la ley 241/1990, con objeto de comprobar que se han respetado los principios de economicidad, eficacia, congruencia, lógica, razonabilidad, objetividad y justicia que siempre deben presidir el ejercicio de dicha acción administrativa en tanto que los hechos de la gestión que se derivan de elecciones discrecionales siempre los puede valorar el juez contable según dichos cánones".

26 Cons. Estado, Sec. IV, 16 de mayo de 2006, n. ${ }^{\circ} 2819$ : “La norma indica como criterio de elección la referencia a las asociaciones y a los movimientos de las mujeres "más representativos en el ámbito nacional”, pero sin especificar las modalidades de confirmación y verificación de dicho requisito. Por lo tanto, es evidente que en presencia de este tipo de disposiciones genéricas constituye una incumbencia precisa de la Administración competente la de determinar los criterios básicos según los cuales se pueden valorar y ponderar comparativamente los elementos presentados por los distintos partícipes del procedimiento, con objeto de realizar elecciones que sean plenamente coherentes con las normas legales y con los requeridos cánones de objetividad y de imparcialidad".

27 Siempre a título de ejemplo, véase Tribunal Const., 22 de febrero de 1985, n. ${ }^{\circ 6}$ : “Con las normas denunciadas se han creado disparidades de trato irracionales e injustificadas entre médicos internos que... habían sido contratados en las clínicas e institutos universitarios sobre la base de los mismos supuestos objetivos y subjetivos... y con las mismas garantías de imparcialidad y objetividad de criterios". Tribunal Const., 19 de marzo de 1993, n. ${ }^{\circ}$ 103: “La disposición impugnada... está formulada de modo que se asegure el respeto de los principios que se asumen violados, y contiene todos los elementos adecuados para garantizar objetividad y coherencia en el ejercicio del poder extraordinario de disolución de los órganos electivos

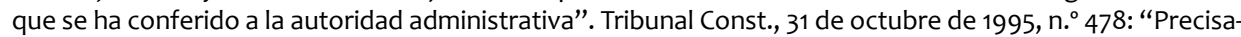
mente faltan las garantías mínimas de objetividad y de buen desarrollo (mediante el recurso a procedimientos congruentes y razonables necesarios para cualquier selección en el sector del empleo público) basadas necesariamente en elementos de actitud para cubrir (ya sea en cuanto a la admisión en el empleo, como al progreso de cualificaciones o de movilidad vertical: sentencia n. ${ }^{\circ} 487$ de 1991) puestos, sobre todo si son de grado medio o alto, cualquiera que sea la forma de acceso, público o limitado a profesiones, o interno". 
Este estudio tiene las finalidades siguientes:

(i) explorar las relaciones entre objetividad e imparcialidad administrativa; esto exige, evidentemente, un "mapeado" preventivo y actualizado de los campos de aplicación del principio de imparcialidad según el art. 97 Const., que se realizará haciendo referencia a la evolución de los estudios sobre la administración hasta los resultados más recientes;

(ii) averiguar si, al menos potencialmente, el principio de objetividad puede aspirar, en el proceso de abstracción del ius positum, a la reconstrucción teórica, a la conquista de un espacio propio autónomo, al aspecto externo o al interno del principio de imparcialidad.

\section{LA IMPARCIALIDAD ADMINISTRATIVA CODIFICADA POR EL ART. 97 CONST. COMO “PRINCIPIO DE PRINCIPIOS”}

Giannini ha observado que la doctrina italiana ha atribuido al principio de imparcialidad indicado en el art. 97 Const. tantos "valores" que dan lugar a una "exageración indudable"28.

Más allá de este juicio severo, es cierto que "el principio está asociado, en cada ocasión, a aspectos de la administración diferentes", hasta el punto de que determinan una "fragmentación del concepto" en una pluralidad de cánones ${ }^{29}$ y que permiten "deducir una serie impresionante de criterios de los caracteres esenciales y muy concisos del art. 97 Const." 30.

En este sentido se puede decir que la imparcialidad administrativa, más que un principio monolítico, es un "principio de principios"31: una especie de multiplicador de cánones de la administración que parte de una energía inagotable.

Metafóricamente se podría describir como un "politopo" multidimensional que presenta múltiples lados axiológicos y prescriptivos.

A continuación se tratarán someramente las principales dimensiones del principio constitucional de imparcialidad, sobre la base de la elaboración de la doctrina italiana.

28 M.S. Giannini, Istituzioni di diritto amministrativo, Milán, Giuffrè, 2000, p. 264.

29 G. Gardini, capítulo Imparzialità amministrativa, en S. Cassese (director), Dizionario di diritto pubblico, vol. IV, Milán, Giuffré, 2006, p. 2936..

30 P. Forte, L'imparzialità come struttura della decisione pubblica amministrativa, en AA.VV., Procedura, procedimento e processo (actas del Convenio de Urbino, 14 y 15 de junio de 2007), Padua, Cedam, 2010, p. 413.

31 V. Cerulli Irelli, Lineamenti del diritto amministrativo, Turín, Giappichelli, 2010, p. 253, define la imparcialidad de un "conjunto de principios". Ya M. Nigro, Studi sulla funzione organizzatrice della pubblica amministrazione, Milán, Giuffré, 1966, p. 193, había observado que la imparcialidad de la que trata el Art. 97 Const. se resuelve en un "conjunto de cánones". 


\subsection{Las múltiples dimensiones de la imparcialidad: organizativa y funcional; subjetiva y objetiva; negativa y positiva}

En primer lugar se han destacado la dimensión organizativa o estructural y la dimensión funcional del principio de imparcialidad ${ }^{32}$.

La imparcialidad en la organización administrativa representa un precepto que "se dirige tanto al legislador como a la administración, estableciendo la regulación de su organización y las medidas concretas de organización", e "impone que la administración se estructure de forma que garantice una condición objetiva de imparcialidad”33.

En este sentido, la imparcialidad organizativa se expresa también en normas específicas de rango constitucional, como aquella (art. 97, párrafo 3, Const.) según la cual "a los empleos en las administraciones públicas se accede por concurso, salvo en los casos previstos por la ley”, o aquella (art. 98, párrafo 2, Const.) según la cual "los empleados públicos... si son miembros del Parlamento, no pueden conseguir promociones si no es por antigüedad"34.

32 El conocimiento consciente de tal duplicidad dimensional (organizativa y funcional) de la imparcialidad está destacada y consolidada en la doctrina italiana, al menos a partir de los años sesenta del siglo $\mathrm{XX}$. Baste con remitirse a las afirmaciones de uno de los más grandes maestros del derecho constitucional, quien observó que el principio de imparcialidad, dictado por el art. 97 Const., tiene "un doble efecto, en el aparato administrativo y en la función que a éste se atribuye": así V. Crisafulli, Principio di legalità e "giusto procedimento", en Giur. cost., 1962, p. 135. Sobre esta doble dimensión, véase U. Allegretti, L'imparzialità amministrativa, Padua, Cedam, 1965, p. 20 (en particular la nota 35); G. Sala, II principio del giusto procedimento nell'ordinamento regionale, vol. I, Milán, Giuffré, 1985, pp. 85 ss.; G. Corso, Manuale di diritto amministrativo, Turín, Giappichelli, 2008, pp. 355 ss. Para una consideración resumida reciente, con amplias referencias jurisprudenciales, nos remitimos a M.R. Spasiano, I principi di pubblicità, trasparenza e imparzialità, en M.A. Sandulli (encargado), Codice dell'azione amministrativa, Milán, Giuffré, 2011, pp. 84-86.

33 E. Casetta, Manuale di diritto amministrativo, Milán, Giuffré, 2010, p. 48.

34 La regla del concurso público como garantía de la imparcialidad organizativa ha sido destacada por el Tribunal Constitucional en numerosas sentencias, entre las que destacan las sentencias n. ${ }^{\circ} 453 / 1990$, 333/1993, 416/1993, 99/1998, 194/2002, 373/2002, 274/2003, 34/2004, 190/2005, 205/2006, 363/2006, 215/2009, 293/2009, 9/2010, 100/2010, 195/2010, 213/2010, 225/2010, 354/2010, 52/2011, 67/2011, 108/2011, 123/2011. Con una referencia específica a los llamados concursos internos, es decir, los reservados a los empleados ya en servicio para su promoción en la carrera, el Tribunal ha afirmado que el principio del concurso público para el acceso a los empleos en las administraciones públicas, cuando el intento consiste en valorar experiencias profesionales adquiridas en el seno de la administración, puede ir en contra de derogaciones y excepciones, pero para que se asegure la generalidad de la regla del concurso público dispuesta por el art. 97 Const., es necesario que el área de las excepciones a la regla sancionada se delimite de modo riguroso desde su primer párrafo: en particular, es indispensable que las excepciones al principio del concurso público estén contenidas numéricamente en porcentajes limitados con respecto a la totalidad de las contrataciones puestas a disposición por la administración; que la contratación corresponda a una necesidad funcional específica de la propia administración; y, sobre todo, que se hayan previsto precauciones adecuadas para asegurar en todo caso que el personal contratado tenga la profesionalidad necesaria para el desempeño del cargo. Para un comentario de la jurisprudencia del Tribunal sobre este punto, véase G. Pastori, Amministrazione, imparzialità e composizione tecnica degli organi di amministrazione del personale, en Le Regioni, 1991, pp. 1504 ss.; R. Cavallo Perin, Pubblico concorso e professionalità dei dipendenti pubblici: un diritto costituzionale dei cittadini, en Foro amm. - CDS, 2002, pp. 1994 ss.; B. Di Giacomo Russo, Concorso pubblico, principio di imparzialità e costituzione amministrativa nella giurisprudenza della Corte costituzionale, en Quad. reg., 2004, pp. 645 ss.; R. Caranta, Art. 97, en R. Bifulco - A. Celotto - M. Olivetti (encargado), Commentario alla Costituzione, Vol. II, Turín, Utet, 2006, pp. 1895 ss. y pp. 1901 ss.; G. Zilio Grandi, Il concorso 
La dimensión organizativa de la imparcialidad ${ }^{35}$ ha sido objeto de profundizaciones admirables a partir de los años sesenta del siglo XX, en especial en las obras de Nigro $^{36}$ y Berti ${ }^{37}$, y se ha desarrollado, en los últimos decenios, sobre todo bajo la perspectiva del principio de distinción entre política y administración (véase infra, par. 3.2.).

Como se ha observado acertadamente, "la organización, objetiva y subjetiva, constituye directamente, como predeterminación pública tendencialmente estable y conocible, unas competencias y unos sujetos llamados a desempeñarlas, y es un fuerte instrumento de garantía de la imparcialidad"38. Bajo esta perspectiva, otra doctrina

pubblico quale strumento ordinario di accesso alle pubbliche amministrazioni, tra regola costituzionale e prassi, en Riv. it. dir. lav., 2007, pp. 269 ss.; B. Gagliardi, Principio del pubblico concorso e professionalità dei pubblici funzionari, en Foro amm. - CDS., 2009, pp. 2799 SS.; A. Pertici, I limiti di derogabilità della regola del concorso pubblico per l'accesso ai pubblici impieghi: una riserva di legge (sempre più) rinforzata in via giurisprudenziale, en Giur. cost., 2010, pp. 3602 ss.

35 La dimensión organizativa del principio de imparcialidad según el art. 97 Const. se expresa en numerosos ámbitos y da lugar a una pluralidad de reglas y de aplicaciones. Como reseña, baste con la remisión a los ejemplos proporcionados por G. Corso, Le norme costituzionali sull'organizzazione, en Aa.Vv., La pubblica amministrazione nella Costituzione: riflessioni e indicazioni di riforma (Actas del XXXIX Convenio de estudios de Ciencia de la administración, Varenna 16-18 de septiembre de 1993), Milán, Giuffré, 1995, en particular en la p. 27 y en las pp. 37 ss.. Como indica Corso, "sería contraria al principio de imparcialidad una concentración de las competencias en los funcionarios honorarios, o sea en las personas que están colocadas en las oficinas en virtud de una investidura electiva, directa o indirecta, o de una investidura política, con exclusión de los funcionarios burocráticos" (op. cit., p. 27); "la imparcialidad influye ... en la composición de los gremios administrativos” (p. 37); "el principio de imparcialidad influye también en las modalidades de investidura en los gremios, y en los oficios unipersonales, sobre todo en relación con el sujeto que proceda a realizar el nombramiento o la elección” (p. 38); "la imparcialidad también influye en los procedimientos de remisión en las oficinas públicas o en el tipo de oficinas una vez hayan cesado los titulares correspondientes" (también p. 38); "el principio de imparcialidad también se ha invocado como fundamento del reparto de competencias administrativas “ (p. 39). Para profundizar más en el tema específico, que tiene gran interés y que afecta a la relación entre el principio de imparcialidad y los gremios administrativos, véase G. Manfredi, Principio di imparzialità e riordino dell'amministrazione per collegi, en Dir. amm., 1996, pp. 89 ss.

36 M. Nigro, Studi sulla funzione organizzatrice della pubblica amministrazione, cit. Según Nigro (pp. 166-167), “la 'ratio’ del art. 97 está en la disciplina y en el reparto de la función de organización ... la intervención del legislador ... está dirigida no solo a proteger, sino también a limitar la independencia de la administración ... en la medida en que está destinada a proteger (aunque limitándola) dicha independencia, no puede llegar a suprimirla ... el peligro ante el que hay que defender a la administración no es solo el de la politicidad 'inducida' a través de la injerencia gubernamental, sino que también es el del desarrollo de una burocracia autocéfala potente, y el de la injerencia excesiva del parlamento que 'induce' una politicidad no menos preocupante. El Art. 97 trata de responder a la defensa de (todos) estos peligros distribuyendo la función de organización como función de la dirección de la administración y equilibrando sus diversos modos de ejercicio".

37 G. Berti, La pubblica amministrazione come organizzazione, Padua, Cedam, 1968.

38 F. Merloni, Organizzazione amministrativa e garanzie dell'imparzialità. Funzioni amministrative e funzionari alla luce del principio di distinzione tra politica e amministrazione, en Dir. pubbl., 2009, pp. 57 ss., respectivamente en p. 99. El propio A., en la p. 98, pone de manifiesto cómo "la organización constituye de por sí, de modo autónomo, una notable garantía para el ciudadano sobre el ejercicio imparcial de las funciones asignadas a las administraciones públicas. La garantía consiste en la predeterminación de funciones (finalidad), en la articulación de las funciones que se desempeñan en el ejercicio y en su distribución entre oficinas establecidas de modo que aseguren el desarrollo adecuado de la actuación administrativa. La organización proporciona una garantía anticipada con respecto al desarrollo de la actuación, pero con- 
ha subrayado el valor del principio de imparcialidad como "parámetro" sobre la base del cual aplicar, también en términos de decisión jurisdiccional, el "control de la violación de normas concernientes a la organización administrativa”39.

La dimensión funcional del principio constitucional de imparcialidad, en cambio, tiene que ver con la actividad administrativa, es decir, con el momento dinámico representado por el desempeño de la función administrativa ${ }^{40}$ a través de procedimientos, actos, medidas, acuerdos, contratos y comportamientos con relevancia externa para los ciudadanos.

En esta acepción, el principio se aplica y especifica en un espectro amplísimo de cánones como la trasparencia, la igualdad de trato, el procedimiento justo, la motivación obligatoria, etc. (sobre estos aspectos véase infra, párrafo 3.3. y párrafo 3.4). Especialmente fuerte es la conexión que surge entre la imparcialidad y el ejercicio, por parte de la administración pública, de un poder con contenido discrecional ${ }^{41}$.

ceptualmente se debe diferenciar bien de aquélla. La función, la competencia y el órgano son nociones propias de la organización administrativa".

39 G. Bottino, Amministrazione e funzione organizzatrice, Milán, Giuffrè, 2008, pp. 162 ss. Según G. Serges, Principi in tema di amministrazione, en F. Modugno (encargado), Lineamenti di diritto pubblico, Turín, Giappichelli, 2010, p. 449, “en el plano de la organización, la imparcialidad se ha entendido sobre todo como el deber de estructurar la administración de forma que quien administre no tenga interés en la materia sobre la que asume decisiones, así como la obligación de reclutar funcionarios de modo imparcial".

40 En cuanto a la imparcialidad en sentido funcional, véase A. Cerri, Imparzialità ed indirizzo politico nella pubblica amministrazione, Padua, Cedam, 1973: A., después de haber definido el principio de imparcialidad como "necesidad de ponderar todos los intereses tutelados por la ley que puedan estar directamente afectados por la actuación administrativa, solo ellos, y proceder a las elecciones consiguientes sobre la base de criterios previstos por la ley o que sean unitarios, esto es, conformes con directrices generales adoptadas por los órganos competentes en función del sistema democrático" (p. 120), afirma que "el principio de imparcialidad se plantea como canon fundamental de desempeño de la función, aunque no consiga aplicar directamente el principio de legalidad" (p. 121) y que "el principio ... que parece peculiar de la actividad administrativa, mientras no esté regulada por normas legislativas precisas, es propiamente el principio de imparcialidad. Por lo tanto, éste constituye la norma fundamental de desempeño de la función” (pp. 123-124). Véase también G. Pastori (coord.), La procedura amministrativa, Vicenza, Neri Pozza, 1964, pp. 64 ss.; S. Cassese, Imparzialità amministrativa e sindacato giurisdizionale, Milán, Giuffrè, 1973, passim; G. Sala, Imparzialità dell'amministrazione e disciplina del procedimento nella recente giurisprudenza amministrativa e costituzionale, en Dir. proc. amm., 1984, pp. 433 ss.; F. Satta, capítulo Imparzialità della pubblica amministrazione, en Enc. giur., Roma, Treccani, vol. XV, 1989, en particular pp. 5 ss.; M. Galdi, Buon andamento, imparzialità e discrezionalità amministrativa, Nápoles, Liguori, 1996; C. Pinelli, Il principio di imparzialità nel pensiero di Aldo M. Sandulli, en Aa.Vv., Aldo M. Sandulli (1915-1984). Attualità del pensiero giuridico del Maestro, Milán, Giuffrè, 2004, pp. 253 ss.; S. Spuntarelli, L'amministrazione per legge, Milán, Giuffrè, 2007, pp. 244 ss.; V. Cerulli Irelli, Lineamenti del diritto amministrativo, cit., pp. 253-254.

41 Según A. Cerri, Istituzioni di diritto pubblico. Casi e materiali, Milán, Giuffré, 2009, pp. 269-270, "la imparcialidad se aplica cuando los parámetros legales no han sido suficientes. De hecho, ésta desemboca en la exigencia de considerar todos y cada uno de los intereses estimados por el ordenamiento vigente (por la Constitución y por las leyes); y según los criterios aplicados uniformemente en los distintos casos... los parámetros legales no son suficientes en supuestos de discrecionalidad propiamente administrativa, que se vincula a una directriz política de mayoría por lo que respecta a los criterios de ponderación entre los intereses concurrentes o de discrecionalidad técnica, que se vincula a una directriz administrativa; o bien, además, cuando la administración actúa mediante instrumentos de derecho común vinculados a una 320 legalidad puramente organizativa o con fines concretos... y en este último caso... la imparcialidad actúa por 
Además, más de una vez la doctrina ha subrayado cómo la dimensión organizativa y la dimensión funcional de la imparcialidad administrativa, a pesar de ser lógicamente distinguibles, están interconectadas de forma inseparable, representando sustancialmente dos caras de la misma moneda ${ }^{42}$.

Asimismo, a lo largo de otro "eje" dimensional, la doctrina ha distinguido entre imparcialidad en sentido subjetivo e imparcialidad en sentido objetivo.

La imparcialidad subjetiva se refiere a cada persona de forma individual (administrador, directivo o empleado) vinculada a la administración pública.

Ésta consiste en un conjunto de normas "que conciernen a la posición individual, personal, del titular de funciones públicas, que garantiza que el sujeto asume la decisión pública no aislado del mundo ("neutralidad abstracta"), pero al menos no condicionado impropiamente por intereses particulares (empezando por sus intereses personales) ante los que el ordenamiento le debe situar en una posición de necesaria distancia"; entran en el ámbito de la imparcialidad subjetiva normas como la imposibilidad de presentar candidatura, la inelegibilidad, la incompatibilidad preventiva y sucesiva, el deber de abstención del funcionario o del administrador en caso de conflicto de intereses, los deberes de comportamiento que se remiten a los cánones de la integridad personal y de la así llamada ética pública, trasmitidos en los códigos de comportamiento de los empleados públicos ${ }^{43}$.

vertido en usual; la competencia por el mercado según una expresión más reciente) que “duplican” la fase contractual”. S. Spuntarelli, Il principio di legalità e il criterio di imparzialità nell'amministrare, en Dir. amm., 2008, pp. 223 ss., después de haber destacado que "el criterio de imparcialidad representa para la administración y para los sujetos privados dedicados al ejercicio de actividades administrativas un instrumento de racionalización de las elecciones impuesto constitucionalmente" (p. 236), subraya que "el criterio de imparcialidad... caracteriza y marca el proceso decisorio en el ejercicio del poder discrecional administrativo" (p. 251).

42 Véase M. Nigro, Studi sulla funzione organizzatrice della pubblica amministrazione, cit., pp. 117 ss.; G. Berti, La pubblica amministrazione come organizzazione, cit., p. 66 e pp. 73 ss.; G. Pastori, La burocrazia, Padua, Cedam, 1967, pp. 87 ss.

43 La cita en el texto está sacada de F. Merloni, Introduzione. L'etica dei funzionari pubblici, en F. Merloni - R. Cavallo Perin (encargado), Al servizio della Nazione. Etica e statuto dei funzionari pubblici, Milán, Franco Angeli, 2009, pp. 16-17; se remite a las distintas contribuciones reunidas en esa obra de recopilación, así como a la monografía de B.G. Mattarella, Le regole dell’onestà: etica, politica, amministrazione, Bolonia, II Mulino, 2007, para el reconocimiento de los múltiples perfiles de la imparcialidad en sentido subjetivo y para las referencias bibliográficas necesarias. Véase también el ensayo de $\mathrm{B}$. Ponti, La nozione di indipendenza nel diritto pubblico come condizione del funzionario, en Dir. pubbl., 2006, pp. 185 ss., en particular pp. 238 ss.

Sobre los códigos de comportamiento de los funcionarios públicos es necesario recordar el art. 54 (titulado precisamente “Código de comportamiento”) del D.Lgs. 165/2001 (“Normas generales sobre el ordenamiento del trabajo en las dependencias de las administraciones públicas”), que dispone lo siguiente:

“1. El Departamento de la función pública, una vez oídas las confederaciones sindicales representativas según lo dispuesto en el artículo 43, define un código de comportamiento de los empleados en las administraciones públicas incluso en relación con las medidas de organización necesarias que se han de adoptar para asegurar la calidad de los servicios que dichas administraciones prestan a los ciudadanos.

2. El código está publicado en la Gazzetta ufficiale (Boletín oficial) y se entrega al empleado en el momento de ser contratado. 
3. Las administraciones públicas formulan para el ARAN directrices, en el sentido del artículo 41, párrafo 1, y del artículo 70, párrafo 4, para que el código se recoja en los contratos, como anexo, y para que sus principios se coordinen con las previsiones contractuales en materia de responsabilidad disciplinaria.

4. Para cada magistratura y para la Abogacía del Estado, los órganos de las asociaciones profesionales adoptan un código ético que se somete a la adhesión de los que pertenecen a la magistratura afectada. En caso de inacción, el código es adoptado por el órgano de autogobierno.

5. El órgano superior de cada administración pública verifica, una vez oídas las organizaciones sindicales representativas como expone el artículo 43 y las asociaciones de usuarios y consumidores, la aplicabilidad del código mencionado en el párrafo 1, también para aportar eventuales complementos y especificaciones con fines de publicación y de la adopción de un código específico de comportamiento para cada administración concreta.

6. Los directivos responsables de cada estructura vigilan la aplicación de los códigos que se tratan en el presente artículo.

7. Las administraciones públicas organizan actividades de formación del personal para que conozcan y apliquen correctamente los códigos que se tratan en el presente artículo".

El art. 54 del D.Lgs. 165/2001 reproduce el anterior art. 58-bis del D.Lgs. 29/1993, más tarde modificado por el art. 27 del D.Lgs. 80/1998.

Al aplicar la versión original del tenor del citado art. 58-bis del D.Lgs. 29/1993, el Ministro de la función pública, con D.M. del 31 de marzo de 1994 (en G.U. n. ${ }^{\circ} 149$ del 28 de junio de 1994), adoptó un primer “Código de comportamiento de los empleados de las administraciones públicas”, único para todas las administraciones públicas (estatales, regionales y locales).

En aplicación de la modificación introducida por el art. 27 del D.Lgs. 80/1998, el Ministro de la función pública, con D.M. del 28 de noviembre de 2000 (en G.U. n. ${ }^{\circ} 84$ del 10 de abril de 2001), adoptó un segundo "Código de comportamiento de los empleados de las administraciones públicas", aún en vigor.

Dicho Código de comportamiento establece lo siguiente: blicas;

— en el art. 2, una serie de "principios" generales inderogables para todas las administraciones pú-

- en los arts. 3 y siguientes, prescripciones más minuciosas: estas últimas, sin embargo, se pueden integrar y especificar en los posteriores códigos de comportamiento que las administraciones públicas concretas pueden adoptar de forma autónoma.

Este esquema explica el florecimiento de una multitud de códigos de comportamiento, disciplinarios y éticos elaborados por las diversas administraciones públicas (también como consecuencia de numerosas leyes regionales promulgadas sobre esta materia).

Nótese que el Código de comportamiento del que trata el D.M. del 28 de noviembre de 2000 le da el título de "Imparcialidad" a un artículo que trata sobre ella. Se trata del art. 8, en el que se establece lo siguiente: en el párrafo 1, que "el empleado, en el cumplimiento de la prestación laboral, asegura la igualdad de trato entre los ciudadanos que entren en contacto con la administración de la que él depende. Con este fin, él no rechaza ni acepta para nadie prestaciones que normalmente se acepten o rechacen para otros"; en el párrafo 2, que "el empleado se atiene a modalidades correctas de desempeño de la actividad administrativa de su competencia, rechazando en particular cualquier presión ilegítima, aunque ésta sea ejercida por sus superiores".

Sin embargo, también otras disposiciones del Código de comportamiento que trata el D.M. del 28 de noviembre de 2000 muestran con seguridad respeto al principio de imparcialidad en su dimensión subjetiva. Baste con considerar las que imponen al empleado público: la obligación de abstenerse en situaciones de conflicto de intereses, aunque solo sean aparentes, que afecten a intereses personales, o intereses de sus propios familiares o personas que con él convivan, o intereses de otros sujetos con los que tenga relaciones de crédito o de deuda, funciones de administración, gestión, representación o garantía, causas pendientes, grave enemistad; la prohibición de aceptar regalos u otros bienes de sus propios subordinados y de sus parientes, así como de sujetos que tengan trato o que de algún modo puedan obtener beneficios de decisiones o actividades inherentes a la oficina; la prohibición de ofrecer regalos u otros bienes a sus propios superiores o a sus familiares o a las personas que con ellos convivan; la obligación de limitar las cumplimentaciones a cargo de los ciudadanos y de las empresas a los que sean indispensables; la obligación de comunicar de forma trasparente su propia afiliación a asociaciones y organizaciones, incluso de carácter no reservado, cuyos intereses estén implicados por el desarrollo de la actividad de la oficina, salvo que se trate de partidos políticos o sindicatos; la prohibición de obligar a otros empleados a que se afilien a asociaciones y organizaciones, o inducirles a hacerlo prometiendo ventajas en su carrera profesional; la 
La imparcialidad objetiva, por el contrario, concierne a la acción y la organización administrativa consideradas en sí mismas, independientemente de las personas físicas que intervengan en concreto.

Ésta se expresa en el conjunto de normas "relacionadas con la organización de las funciones públicas y el desarrollo de la acción: distribución de las competencias, constitución de oficinas y órganos, configuración de los caracteres de los titulares de las oficinas/órganos; procedimientos, trasparencia sobre la organización y las decisiones, controles (no solo técnicos y administrativos, sino también democráticos)" ${ }^{44}$.

En otros términos, la imparcialidad en sentido subjetivo genera normas sobre quién toma las decisiones administrativas (organizativas o funcionales), y la imparcialidad en sentido objetivo regula cómo se deben tomar dichas decisiones ${ }^{45}$.

La distinción entre imparcialidad subjetiva y objetiva (dimensiones que, en todo caso, se implican entre $\mathrm{si}^{46}$ ) no se puede superponer totalmente a la distinción entre

obligación de trasparencia en los intereses financieros personales o de sus propios familiares o de las personas que convivan con ellos (en particular, el empleado debe dar a conocer todas las relaciones de colaboración retribuida de alguna forma que haya tenido en el último quinquenio, precisando si él, sus familiares o las personas que con él convivan tienen todavía relaciones financieras con el sujeto con el que él haya tenido dichas relaciones de colaboración, y si dichas relaciones están relacionadas con o relacionan a sujetos que tengan intereses en actividades o decisiones inherentes a la oficina, limitadas a las prácticas que a él se han confiado; en cuanto a los directivos, antes de que éstos asuman sus funciones deben comunicar a la administración las participaciones en acciones y demás intereses financieros que puedan situarles en conflicto de intereses, y declarar si tienen familiares, personas afines o con las que convivan que ejerzan actividades políticas, profesionales o económicas que les pongan en contacto frecuente con la oficina o que estén implicadas en las decisiones o en las actividades inherentes a la oficina); la prohibición de aceptar encargos de colaboración con individuos u organizaciones que tengan, o hayan tenido en el bienio precedente, un interés económico en decisiones o actividades inherentes a la oficina; la obligación de prestar atención adecuada a las preguntas de los ciudadanos y de proporcionar las explicaciones que se les pidan en cuanto a su propio comportamiento y el de otros empleados de la oficina; en el trato de las actuaciones, la obligación de respetar el orden cronológico y de no rehusar prestaciones que deba realizar alegando en general la cantidad de trabajo por hacer o la falta de tiempo disponible; la prohibición de aceptar encargos o hacer promesas sobre decisiones propias o ajenas inherentes a la oficina si esto puede generar o confirmar desconfianza en la administración o en su independencia e imparcialidad; la obligación de utilizar un lenguaje claro y comprensible en la redacción de los textos escritos y en todas las demás comunicaciones; la prohibición de estipular por cuenta de la administración contratos de adjudicación, suministro, servicio, financiación o seguros con empresas con las que haya estipulado contratos a título privado en el bienio precedente; la obligación de abstenerse de participar en la adopción de decisiones y en las actividades relativas a la ejecución de la contrata en el caso de que la administración celebre contratos de adjudicación, suministro, servicios, financiación o seguros con empresas con las que él haya celebrado contratos a título privado en el bienio precedente; la obligación de informar a la administración sobre el hecho de haber celebrado contratos a título privado con empresas con las que, en el bienio precedente, haya celebrado contratos de adjudicación, suministro, servicios, financiación y seguros por cuenta de la administración misma, etc.

44 F. Merloni, Introduzione. L'etica dei funzionari pubblici, cit., p. 16.

45 Así D. Sorace, Diritto delle amministrazioni pubbliche. Una introduzione, Bolonia, II Mulino, 2010, pp. 348-352.

46 Según F. Benvenuti, Disegno dell'Amministrazione Italiana. Linee positive e prospettive, Padua, Cedam, 1996, p. 240, "la imparcialidad asume así un doble significado en cuanto que es característica de la 
imparcialidad organizativa y funcional. Las dos dicotomías no coinciden; es más, se entrelazan en una geometría pluridimensional.

De hecho, la imparcialidad subjetiva actúa en el plano de la organización (por ejemplo, un conflicto de intereses del directivo público que llegue a manifestarse en el momento en que él está llamado a adoptar actos de organización de su función, o a expresar una valoración sobre el acceso, la adscripción y el ascenso en la carrera de otros funcionarios en la posición organizativa, o a respetar las obligaciones y prohibiciones de comportamiento en las relaciones interorgánicas con otros funcionarios o directivos públicos), como en el ámbito de la actividad administrativa (manteniendo el mismo ejemplo, un conflicto de intereses del directivo público que surja en el momento en el que él interactúa con sujetos privados en el ámbito de un procedimiento administrativo, o aplica medidas, acuerdos, contratos, etc.). Lo mismo vale para la imparcialidad objetiva.

Finalmente, se ha destacado un tercer "eje" con el que es posible distinguir entre una dimensión negativa y una dimensión positiva del principio de imparcialidad.

Entendida en sentido negativo, la imparcialidad se traduce en la "prohibición de discriminación"47, que impone a la administración no caer en "favoritismos"48, "preferencias" 49 o "disparidades de trato" 50.

En cambio, la imparcialidad en sentido positivo, o inclusivo ${ }^{51}$, corresponde a una concepción diferente ${ }^{52}$.

Administración como sujeto agente y, al mismo tiempo, es también característica de su actuación: dos caras, la subjetiva y la objetiva, ambas indisolublemente unidas hasta el punto de que un defecto de imparcialidad en la acción repercute en la forma de ser del sujeto y viceversa".

47 Este es el “común significado negativo” de la imparcialidad según G. Gardini, L'imparzialità tra attività e organizzazione amministrativa, en AA.VV., Procedura, procedimento e processo, cit., p. 383. Véase además V. Cerulli Irelli, Lineamenti, cit., p. 253.

48 M.S. Giannini, Diritto amministrativo, vol. I, Milán, Giuffrè, 1988, p. 91, según el cual “quizá sea más exacto limitar el alcance del principio y reconocer en él la prohibición de favoritismos ... no se han de valorar intereses políticos de parte, ni intereses particulares de grupos de presión públicos o privados, ni se pueden usar favores ni odia...".

49 Según S. Cassese (encargado), Istituzioni di diritto amministrativo, Milán, Giuffré, 2009, p. 13, "la parte negativa de la imparcialidad... comporta la prohibición de favoritismos, preferencias y discriminaciones".

50 Identificaba el contenido fundamental de la imparcialidad administrativa en la prohibición de la diferencia de trato, en particular P. Barile, Il dovere di imparzialità della pubblica amministrazione, en Scritti giuridici in memoria di Pietro Calamandrei, vol. IV, Padua, Cedam, 1958, pp. 25 ss.

51 Así también G. Gardini, L'imparzialità tra attività e organizzazione amministrativa, en Aa.Vv., Procedura, procedimento e processo, cit., siempre en la p. 383. Véase también C. Cudia, Funzione amministrativa e soggettività della tutela: dall'eccesso di potere alle regole del rapporto, Milán, Giuffré, 2008, p. 335, nota 26.

52 Según A. Crosetti - A. Giuffrida, Lineamenti di diritto amministrativo, Turín, Giappichelli, 2009, p. 142, “la noción de 'imparcialidad' asume una doble valencia, negativa y positiva. Sobre todo (perfil negativo), el principio impone a la administración pública que se dirija a los ciudadanos sin aplicar discriminaciones al defender los intereses que se le han confiado (deber negativo). Además, la administración pública (perfil positivo), al no poder privilegiar intereses particulares, está llamada también a identificar y valorar 324 todos los intereses implicados en su actuación para que la medida final asumida logre la plena moderación; es decir, debe conseguir un equilibrio imparcial de las relaciones (obligación positiva)". 
La administración pública (tanto en la dimensión subjetiva de los funcionarios que la componen como en la dimensión objetiva de las modalidades y de los métodos de su función) debería abrirse con integridad, verdad y justicia a la consecución, a la consideración y la comparación de todos los intereses protegidos en todo caso por el ordenamiento del que son titulares sujetos privados u otros sujetos públicos, cada vez que dichos intereses, protegidos por la normativa, estén involucrados en la adopción de una decisión administrativa que deba tomarse en el plano organizativo o en el plano funcional. Esto con el objetivo de llegar a un equilibrio y a una síntesis global, lo más omnicomprensiva posible, entre dichos intereses y el interés público primario y específico del que la propia administración que decide es titular por atribución normativa.

Es decir, en su sentido positivo, la imparcialidad es al todo (el conjunto de los intereses en juego) como la parcialidad es a la parte (la persecución del interés del que se es portador llevada a cabo de forma autorreferencial y desanclada de la consideración del conjunto de los intereses protegidos que están en juego) ${ }^{53}$.

De esta forma, en las relaciones con los ciudadanos, la administración actúa como "parte" (porque es portadora del interés público primario, aunque éste puede chocar con intereses públicos y privados secundarios), pero se cualifica, según una conocida definición de Allegretti, como "parte imparcial" (porque se abre de forma plena a la satisfacción y la consideración de todos los intereses secundarios, públicos y privados, para compaginarlos con el interés público primario y llevar este último del plano abstracto de la ley al plano concreto de las relaciones sociales vivas y reales $)^{54}$.

53 Esta concepción se debe sobre todo a la obra de U. Allegretti, L'imparzialità amministrativa, Padua, Cedam, 1965, passim (v., en particular, pp. 37 ss., 58, 70, 76, 113 ss., 205). Posteriormente la desarroIló, con correcciones significativas, A. Cerri, Imparzialità ed indirizzo politico nella pubblica amministrazione, cit., pp. 71 ss. y pp. 120 ss. (para el pensamiento de este autor véase retro, nota 40). Con referencia específica al concurso público, una afirmación clara en el sentido de que "el principio establecido por el art. 97 de la Constituzione tiene un doble significado: uno 'negativo' y uno 'positivo"” se vuelve a encontrar en Tribunal Const., sentencia n. ${ }^{\circ} 333$ del 23 de julio de 1993. S. Lariccia, Origini storiche e fondamento costituzionale del principio di imparzialità delle pubbliche amministrazioni, en Aa.Vv., Studi in onore di Giorgio Berti, vol. II, Nápoles, Jovene, 2005, pp. 1379-1381, después de haber recordado que "la obligación de imparcialidad impuesta a la administración no se opone a la posición de parte que es inherente a la propia administración en sus relaciones con los sujetos destinatarios de la actuación administrativa" y que "en el derecho administrativo, el principio de imparcialidad se expresa en la exigencia de garantizar una valoración comparativa de todos los intereses legislativamente tutelados", resume el concepto positivo de imparcialidad con la fórmula "parcialidad = parte, imparcialidad = todo".

54 También U. Allegretti, L'imparzialità amministrativa, cit., en particular p. 30 e pp. 57-58. Para la observación según la cual “la expresión “parte imparcial” equipara la administración pública al ministerio público “, véase A. Cerri, Istituzioni di diritto pubblico, cit., p. 273. Véase también L.R. Perfetti, Amministrazione pubblica e diritto amministrativo, in Id. (encargado), Manuale di diritto amministrativo, Padua, Cedam, 2007, p. 15, según el cual "aunque la administración es parte de la relación jurídica, en ella se debe comportar como parte imparcial, esto es, como parte que no actúa en función de un interés propio, sino de un interés que le ha sido asignado -el interés público- por la ley... a la cual se requiere, por tanto, que sea imparcial ... el interés público, por tanto, resultará de la ponderación imparcial de todos los intereses presentes en los hechos, y toda la actuación pública y su forma de organizarse deberán estar sujetas a este principio". 
La imparcialidad en sentido positivo e inclusivo se vincula, evidentemente, a las normas que controlan y garantizan la participación de los portadores de los intereses protegidos en el desarrollo de la acción administrativa, en especial a través del procedimiento administrativo ${ }^{55}$.

55 Al respecto, véase $\mathrm{G}$. Barone, L'intervento del privato nel procedimento amministrativo, Milán, Giuffrè, 1969, pp. 46 ss.; F. Satta, capítulo Imparzialità della pubblica amministrazione, cit., pp. 5 ss.; F. Benvenuti, L'impatto del procedimento nell'organizzazione e nell'ordinamento (quasi una conclusione autobiografica), en Aa.Vv., Le ragioni del diritto, Scritti in onore di Luigi Mengoni, vol. III, Milán, Giuffrè, 1995, pp. 1723 ss., publicado ahora en F. Benvenuti, Scritti giuridici, vol. V, Milán, Vita e Pensiero, 2006, pp. 4381 ss., en particular p. 4387; G. Morbidelli, Stato democratico e modelli di amministrazione, en A. Vignudelli (encargado), Istituzioni e dinamiche del diritto. I confini mobili della separazione dei poteri, Milán, Giuffré, 2009, p. 224; D. Sorace, Diritto delle amministrazioni pubbliche, cit., p. 67, según el cual "el principio de la confrontación parece un corolario constitucionalmente necesario del principio de imparcialidad”. La relación entre el principio de imparcialidad, la concepción de la administración pública como "parte imparcial” y el procedimiento administrativo los interpreta F. Benvenuti, Disegno dell'Amministrazione Italiana. Linee positive e prospettive, cit., en el sentido de la "paridad" de la relación entre la Administración y el ciudadano. Según el autor (op. cit., pp. 164-165), "el principio de imparcialidad... sitúa a la Administración en un plano de paridad con el ciudadano... la imparcialidad de la Administración es radicalmente distinta de la imparcialidad que caracteriza el ejercicio de la función jurisdiccional y, por lo tanto, la posición de los jueces en la relación procesal. Mientras que estos últimos nunca son parte, puesto que son ajenos a las relaciones que existen entre los contendientes y por ello son neutrales (neuter), la Administración es parte activa de la relación, pero de una relación que, por efecto de este principio, más que ser autoritaria es paritaria, es decir, no es la única parte, sino una de las partes a las que compete satisfacer un interés común a las demás partes de la relación"; se deduce (op. cit., pp. 237-239) que "un elemento sustentador de la función y del procedimiento es la característica de imparcialidad ... el interés público, que se llamaba así porque correspondía a la Administración Pública (y viceversa), se considera hoy como un interés general o interés de la colectividad y, por lo tanto, de sus miembros. Por lo tanto, a la Administración no le compete ya la función de único intérprete de un interés que ella subjetiviza, sino que es uno de los intérpretes de una pluralidad de intereses que se objetivan como interés colectivo ... de todos modos, ya que a la Administración le corresponde siempre la decisión definitiva, ella no puede considerarse como parte, sino como partícipe en el ejercicio de la función con una posición que debe tender a reconocer a cada uno de los demás participantes el derecho a coadministrar. En este sentido se perfila la cualidad de la Administración como sujeto imparcial, esto es, como sujeto que no debe ser el único conductor de la función, sino que debe reconocer su propia parte a cada uno de los demás involucrados en el procedimiento. Todo esto significa un profundo vuelco en la forma de concebir la Administración debido a lo que se ha llamado la relación paritaria, en la que, manteniéndose el poder decisorio de la Administración, el desempeño de la función se produce bajo la perspectiva de la verdad y, por lo tanto, de la imparcialidad... se puede deducir la diferencia que sigue existiendo entre la estructura del procedimiento jurisdiccional y del procedimiento administrativo. Ya se ha dicho cómo en la función jurisdiccional la posición del juez es la de un sujeto neutro que no se alía y no defiende ninguna posición de parte. En este sentido, la imparcialidad del juez parece de pronto ser distinta de la imparcialidad de la Administración; la imparcialidad del juez significa que éste es objeto ajeno al litigio y, por lo tanto, a la definición de los intereses involucrados en una relación de controversia; la imparcialidad de la Administración no hace que sea neutral entre dos litigantes, sino que, como se suele decir, es parte imparcial hasta el punto de poder tomar la decisión final sobre la base del principio de la confrontación ... todo está ordenado de antemano para que la Administración que decide esté en condiciones de de actuar según la imparcialidad, lo cual, en definitiva, no significa otra cosa más que la justa consideración y el debido respeto de los intereses de la Administración misma, así como de los participantes en el procedimiento. De este modo, está claro cómo las normas del procedimiento se inspiran en las normas del proceso jurisdiccional, adaptándolo según las exigencias de de una función que de todos modos sigue siendo administrativa”. Recientemente retoma estas consideraciones P. Forte, Il procedimento amministrativo, en G. Palma (encargado), Lezioni. Corso di perfezionamento in amministrazione e finanza degli Enti locali: anni accademici 2006-2007 e 2007-2008, Nápoles, ESI, 2009, en particular pp. 56-62; en el mismo volumen, véase la aportación de L.R. Perfetti, /l procedimento amminis- 


\section{2. (sigue) Distinción entre política y administración. Neutralidad e independencia}

Como se ha adelantado, el principio de imparcialidad en sentido organizativo se ha desarrollado en la última veintena de años sobre todo a través de la afirmación, tanto por parte del legislador y de la jurisprudencia constitucional y administrativa como por la doctrina, del modelo de la distinción (o diferenciación funcional) entre política (o dirección) y administración (o gestión).

En síntesis extrema, el modelo de la distinción abate la relación jerárquica entre políticos y burócratas o la sustituye por una relación de dirección en la que:

- por un lado, se han delimitado y limitado las actividades de competencia de los órganos de gobierno (es decir, a escala política), a las que se asigna el poder y la responsabilidad de identificar de forma preventiva y general los objetivos de la acción pública, los plazos dentro de los cuales tendrán que alcanzarse dichos objetivos, el orden de prioridad entre ellos, la atribución de los recursos financieros utilizables para este fin y los mecanismos de vigilancia, control y medición para verificar el logro de los propios objetivos;

- por otro lado, se reservan a la esfera de competencia de los directivos administrativos (es decir, a escala burocrática) todas las demás actividades administrativas necesarias para aplicar la orientación política y, en especial, la aplicación de actos y medidas administrativas, incluidos todos los actos que comprometen la administración hacia el exterior, con plena asunción de responsabilidad por parte de los directivos, de forma exclusiva, sobre la gestión y sus resultados ${ }^{56}$.

56 Las principales etapas normativas de la afirmación del modelo de la distinción entre política y administración han sido la L. 142/1990 (la reforma de las autonomías locales), luego traspuesta al D.Lgs. 267/2000 (Texto único de las leyes sobre el ordenamiento de los entes locales); el D.lgs. 29/1993 (la llamada primera privatización del empleo público) y los posteriores D.Lgs. 80/1998 y 387/1998 (la llamada segunda privatización del empleo público), que luego confluyeron en el D.Lgs. 165/2001 (Normas generales sobre el ordenamiento del trabajo en las dependencias de las administraciones públicas), este otro modificado, entre otras medidas relevantes, por la L. 145/2002, la L. 286/2006, el D.Lgs. 150/2009 (la llamada Reforma 'Brunetta') y la L. 122/2010. Tanto el Tribunal Constitucional como la jurisprudencia administrativa, con numerosas sentencias, han intervenido con objeto de delinear los fundamentos, los límites y las especificaciones de aplicación del modelo de la distinción: amplias referencias jurisprudenciales se plasman en las obras doctrinales que se citan a continuación (seleccionadas con referencia a la última década). A. Pioggia, $L a$ competenza amministrativa: l'organizzazione fra specialità pubblicistica e diritto privato, Turín, Giappichelli, 2001; G. Gardini, Imparzialità amministrativa e nuovo ruolo della dirigenza pubblica, en Dir. amm., 2001, pp. 39 ss. (y también en p. 54, véase el concepto de “diferenciación funcional”); Id., L'imparzialità amministrativa tra indirizzo e gestione, Milán, Giuffré, 2003; M. De Benedetto (encargado), Istituzioni, politica e amministrazione. Otto paesi europei a confronto, Turín, Giappichelli, 2005; P. Forte, Il principio di distinzione tra politica e amministrazione, Turín, Giappichelli, 2005; F. Merloni, Dirigenza pubblica e amministrazione imparziale: il modello italiano in Europa, Bolonia, II Mulino, 2006; Id., Organizzazione amministrativa e garanzie dell'imparzialità. Funzioni amministrative e funzionari alla luce del principio di distinzione tra politica e amministrazione, en Dir. pubbl., 2009, pp. 57 ss.; M. Sgroi, Dalla contrattualizzazione dell'impiego all'organizzazione privatistica dei pubblici uffici, Turín, Giappichelli, 2006; M. Cresti, Efficienza e garanzie nell'evoluzione 
La idea de fondo que inspira dicho modelo es aquella según la cual tanto la orientación política como la administrativa ${ }^{57}$ para con la administración deben obviamente reservarse a los órganos de gobierno, en cumplimento del principio democrático fundamental expresado en el ejercicio de la soberanía popular, pero todo el ámbito de actuación en los casos concretos de dicha orientación política y administrativa, precisamente para garantizar la imparcialidad de la incidencia especial y selectiva en los

dell'organizzazione statale, Milán, Giuffré, 2006; P. Cerbo, Potere organizzativo e modello imprenditoriale nella pubblica amministrazione, Padua, Cedam, 2007; J.B. Vera, Imparzialità vs. indirizzo politico: le variabili del rapporto tra politica e amministrazione nella dinamica delle istituzioni, en Dir. amm., 2007, pp. 15 ss.; A. Massera, Il difficile rapporto tra politica e amministrazione: la Corte Costituzionale alla ricerca di un punto di equilibrio, en Giorn. dir. amm., 2007, pp. 1307 ss.; G. Gruner, L'impossibile rivincita del merito sulla fiducia e le garanzie del procedimento nei rapporti tra politica e amministrazione, en Foro amm. - CDS, 2007, pp. 279 ss.; F. Merloni - R. Segatori - A. Pioggia (encargado), L'amministrazione sta cambiando? Una verifica dell'effettività dell'innovazione nella pubblica amministrazione, Milán, Giuffré, 2007; V. Gasparini Casari, La dirigenza pubblica nel rapporto tra politica e amministrazione (del D.Lgs. 29/1993 al D.Lgs. 150/2009), en Dir. econ., 2009, pp. 543 ss.; M. Midiri, I rapporti tra politica e amministrazione nella giurisprudenza costituzionale e la riforma della dirigenza, allí, 2009, pp. 795 ss.; S. Battini, L'autonomia della dirigenza pubblica e la 'riforma Brunetta': verso un equilibrio fra distinzione e fiducia?, en Giorn. dir. amm., 2010, pp. 39 ss.; B.G. Mattarella, Politica e amministrazione negli enti pubblici, allí, 2010, pp. 207 ss.; I. Sigismondi, Il principio del buon andamento tra politica e amministrazione, Nápoles, Jovene, 2011, pp. 102 ss.. Para aplicaciones en ámbitos específicos del modelo de distinción o diferenciación funcional entre directriz política y gestión administrativa, adde M.G. Urso, Il principio di distinzione tra funzioni di indirizzo politico e di gestione negli enti locali e nelle società partecipate da enti pubblici, en Riv. Corte Conti, 2006, pp. 306 ss.; A. Pioggia, Direzione e dirigenza nelle aziende sanitarie. Una analisi della distribuzione del potere decisionale alla luce degli atti aziendali, en Sanità pubblica e privata, 2008, pp. 5 ss.; P. Giangaspero, Alcune riflessionisull'evoluzione recente dell'organizzazione amministrativa regionale, con riguardo al rapporto tra politica e amministrazione negli ordinamenti regionali, en Le Regioni, 2009, pp. 3 ss.; V. Italia, I rapporti tra politica ed amministrazione nelle amministrazioni locali, en Dir. econ., 2009, pp. 509 ss.; V. Cerulli Irelli, Politica e amministrazione tra atti 'politici' e atti 'di alta amministrazione', en Dir. pubbl., 2009, pp. 101 ss.; M.C. Claudi, Funzione di indirizzo politico e funzione di gestione delle aziende sanitarie, en Ragiusan, 2010, pp. 15 ss.; F. Trimarchi, In tema di rapporti tra politica e amministrazione: la nomina dei rappresentanti del Comune e della Provincia presso enti, aziende ed istituzioni, alla luce di un recente orientamento del Consiglio di Stato, en Foro amm. - CDS, 2010, pp. $622 \mathrm{ss.}$

57 Sobre las diversas teorías elaboradas por la doctrina en cuanto a las relaciones entre "directriz política "y "directriz administrativa " nos remitimos, para ver un esquema actualizado, a la monografía de M.P. Genesin, L'attività di alta amministrazione fra indirizzo politico e ordinaria attività amministrativa. Riflessioni critiche su un sistema di governo multilivello, Nápoles, Jovene, 2009. Allí, en particular en las pp. 61-85, al referir las diversas posiciones en la materia, la Autora defiende la teoría 'dualista' de la distinción conceptual entre la directriz política en sentido propio (expresión de actividad política autocreadora de los propios fines, que compete solamente a los órganos constitucionales que detentan el poder político, es decir: el cuerpo electoral, el Parlamento y el Gobierno, para el Estado; el cuerpo electoral, el Consejo Regional y la Junta Regional, para las Regiones) y la directriz administrativa (expresión de actividad administrativa con un alto índice de discrecionalidad, no autocreadora de sus propios fines, sino heterolimitada y vinculada a los fines establecidos por los actos que son expresión de la directriz política, correspondiente a los órganos de gobierno legitimados políticamente y políticamente responsables, tales como los ministros, el Consejo de ministros, el Presidente del Consejo de ministros, por el Estado; el Alcalde, el Presidente de la Provincia, la Junta municipal y provincial, etc., por las entidades territoriales). En cualquier caso, como indica la Autora (pp. 144-146), hay que afirmar, sobre la base del modelo expuesto en el art. 95 Const., "el principio por el cual, para dirigir la actuación de los poderes públicos, es necesario estar legitimado por la voluntad popular soberana de forma directa o indirecta, con la consiguiente asunción de responsabilidades política cara al órgano elector. Por otra parte, en un régimen democrático no podría ser de otra manera”; por lo tanto, del "principio de la necesaria correlación entre el poder de dirección, ya sea administrativo o, con mayor razón, político, y la responsabilidad política" se deriva que también "la titularidad de los poderes de dirección administrativa se debe conjugar con la asunción de responsabilidad política”. 
ciudadanos, más allá de cualquier preferencia política vinculada a contingencias partidistas, se debe reservar a un cuerpo técnico especializado, o sea a la burocracia, a la que se accede por concurso público y que, según lo previsto en el art. 98 Const., está “al servicio exclusivo de la Nación" en su conjunto, no de sus partes ${ }^{58}$.

Obviamente, el modelo de la distinción entre política y administración plantea unos problemas de aplicación relevantes en relación con cuestiones muy debatidas como, por ejemplo, el status de los directivos públicos y los procedimientos de nombramiento y revocación de los cargos de dirección, así como su duración ${ }^{59}$; las modalidades de vínculo y colaboración (si bien distinguiendo las competencias) entre órganos políticos y órganos administrativos ${ }^{60}$; los límites de compatibilidad constitucional

58 Como ya ha observado el Tribunal Constitucional en la sentencia n. ${ }^{\circ} 333$ del 23 de julio de 1993 , el principio de imparcialidad sobre el que versa el art. 97 Const. hace necesaria "la distinción más profunda entre política y administración, entre la actuación del "gobierno" -que, en las democracias parlamentarias, está normalmente vinculada a los intereses de una parte política, expresión de las fuerzas que ostentan la mayoría- y la actuación de la "administración" -que, al aplicar la directriz política de la mayoría, está sin embargo forzada a actuar sin distinción de partes políticas, para perseguir las finalidades públicas objetivadas por el ordenamiento", en una "perspectiva ligada a la propia fijación constitucional del poder administrativo en el marco de una democracia pluralista". En el mismo sentido, Tribunal Const., 23 de marzo de 2007, n. ${ }^{\circ} 104$, según el cual "los arts. 97 y 98 Const. son corolarios de la imparcialidad, en lo cual se expresa la distinción entre política y administración”. Según E. Casetta, Manuale di diritto amministrativo, cit., p. 38, el ordenamiento parte del "supuesto de que un órgano no político pueda actuar de un modo generalmente imparcial ... porque está liberado de preocupaciones por buscar el consenso político”. Así también G. Corso, Manuale di diritto amministrativo, Turín, Giappichelli, 2006, p. 57, según el cual "solo el titular de una oficina que tenga una investidura profesional, y no deba enfrentarse a problemas de consenso, puede actuar de modo imparcial". Subraya la derivación directa del modelo de la distinción del principio de imparcialidad que trata el art. 97 Const. G. Rossi, Diritto amministrativo. I. Principi, Milán, Giuffré, 2005, p. 134.

59 Al respecto véase en particular, además de las contribuciones citadas en la anterior nota 56, G. Gardini, I/ conferimento di incarico dirigenziale tra politica e amministrazione, en F. Merloni - A. Pioggia (encargado), Riforme organizzative e atti amministrativi, Rimini, Maggioli, 2005, pp. 61 ss.; A. Police, Gli incarichi dirigenziali, le dispute di Pomponazzi e le garanzie del diritto pubblico, en Dir. econ., 2009, pp. 529 ss.; S. Glinianski, Riforma Brunetta: il conferimento e la revoca degli incarichi dirigenziali tra la fiduciarietà del rapporto e il rispetto di un giusto procedimento 'negoziale', en www.lexitalia.it, 2010; P. Monea - M. Mordenti, Nuove regole sugli incarichi dirigenziali negli EE.LL. e nelle Regioni a Statuto ordinario. La questione controversa degli incarichi a termine dopo la riforma voluta da Brunetta, en www.lexitalia.it, 2010; E.A. Apicella, Conferme e novità in tema di incarichi dirigenziali dopo la "riforma Brunetta", en Foro amm. - CDS, 2010, pp. 1327 ss.; P. Fuso, I principi in materia di conferimento degli incarichi dirigenziali: il giusto procedimento, en $\mathrm{M}$. Tiraboschi - F. Verbaro, La nuova riforma del lavoro pubblico. Commento alla Legge 4 de marzo de 2009, n. ${ }^{\circ} 15$, e al Decreto legislativo 27 de octubre de 2009, $n .^{\circ} 150$, Milán, Giuffré, 2010, pp. 559 ss.

60 Al respecto véase en particular, además de las contribuciones citadas en las anteriores notas 56 y 59, M. D’Orsogna, Programmazione strategica e attività decisionale della pubblica amministrazione, Turín, Giappichelli, 2001; G. D’Alessio, La disciplina della dirigenza pubblica: profili critici ed ipotesi di revisione del quadro normativo, en Lav. pubbl. amm., 2006, pp. 549 ss., en particular p. 558; S. Battini, capítulo Dirigenza pubblica, en S. Cassese (director), Dizionario di diritto pubblico, Milán, Giuffrè, 2006, vol. III, pp. 1859 sS., en particular p. 1862; C. D’Orta - A. Boscati, Politica e amministrazione, en F. Carinci - L. Zoppoli (encargado), II lavoro nelle pubbliche amministrazioni, Turín, Utet, 2004, p. 969; F. Merloni, L'etica dei soggetti con incarico fiduciario, en F. Merloni - R. Cavallo Perin (encargado), A/servizio della Nazione. Etica e statuto dei funzionari pubblici, cit., pp. 88 ss. Bajo la perspectiva de los estudios de public management, véase A. Spano, I/ sistema di controllo manageriale nella pubblica amministrazione, Milán, Giuffrè, 2009, pp. 86 ss. e pp. 126 ss.; N. Stame, La valutazione dei dirigenti alla luce della Riforma Brunetta, en G. Urbani (encargado), Valutare le pubbliche amministrazioni: tra organizzazione e individuo. Visioni dei valutatori italiani per performance e competitività, Milán, Franco Angeli, 2010, en particular pp. 177 ss. 
de mecanismos así llamados de spoils system, que relacionen más o menos automáticamente el cese de los altos directivos con el cambio de la mayoría de gobierno tras unas competiciones electorales ${ }^{61}$.

El modelo de distinción entre política y administración, que se ha delineado resumidamente hasta aquí, es ciertamente una hipóstasis del principio de imparcialidad en la dimensión organizativa.

En cambio, la doctrina no es unánime sobre la posibilidad de remisión al principio de imparcialidad del modelo diferente de separación entre política y administración, que encuentra su manifestación más clara en las autoridades independientes ${ }^{62}$.

61 La bibliografía sobre la problemática compatibilidad entre el principio constitucional de imparcialidad y las disposiciones normativas estatales y regionales, que en varios campos han introducido mecanismos de spoils system, es amplísima. Da cuenta de la evolución de la jurisprudencia del Tribunal Constitucional sobre este punto, que pasó de una primera fase de mayor apertura a una segunda y más reciente fase de neto menoscabo del spoils system, permitido solo para el área particular y restringida de la dirección llamada “apical”, es decir, la que está marcada por la inmediata proximidad y una mayor cohesión con respecto al nivel político y por el papel de intermediación entre éste y el área más amplia de la dirección "profesional": esta última, por el contrario, ha sido privada totalmente del spoils system por el Tribunal, precisamente por la necesidad de respetar el modelo de la distinción entre política y administración impuesto por el principio de imparcialidad. A continuación se señalan algunas contribuciones: C. Pinelli, L'avallo del sistema delle spoglie, ovvero la vanificazione dell'art. 97 Const., en Giur. cost., 2006, pp. 2357 ss.; F.G. Scoca, Politica e amministrazione nelle sentenze sullo spoils system, allí, 2007, pp. 1015 ss.; F. Merloni, Lo spoils system è inapplicabile alla dirigenza professionale: dalla Corte nuovi passi nella giusta direzione, en Le Regioni, 2007, pp. 836 ss.; Id., Spoils system: il timore dell'overruling impedisce alla Corte di fare chiarezza, allí, 2010, pp. 1136 ss.; N. Pasini, Lo spoils system fa male alla democrazia? Politica e pubblica amministrazione, Turín, Giappichelli, 2007; G. D’Alessio (encargado), L'amministrazione come professione: i dirigenti pubblici tra spoils system e servizio ai cittadini, Bolonia, II Mulino, 2008; M. Midiri, La Corte, i politici e lo spoils system, en Dir. pubbl., 2008, pp. 927 ss.; S. Spuntarelli, Struttura e ratio delle disposizioni sullo spoils system, en Giur. cost., 2008, pp. 3967 ss.; P. Sordi, La giurisprudenza costituzionale sullo spoils system e gli incarichi dirigenziali nelle pubbliche amministrazioni, en Arg. dir. lav., 2009, pp. 77 ss.; G. Amoroso, Dirigenza pubblica e "spoils system" nella giurisprudenza costituzionale, en Foro it., 2009, I, pp. 1332 ss.; C. Tubertini, Organismi di garanzia e confini del cd. spoils system, en Foro amm. - TAR, 2009, pp. 2507 ss.; M. Magri, Lo spoils system di inizio legislatura, en Giorn. dir. amm., 2010, pp. 605 ss.; L. Fiorillo, Incarichi di funzione dirigenziale e spoils system: la Corte costituzionale definisce il quadro di operatività dell'istituto, en Giur. cost., 2010, pp. 2693 ss..

62 Sobre la profunda diferencia entre el modelo de la distinción y el modelo de la separación entre política y administración, véase F. Merloni, Amministrazione 'neutrale' e amministrazione imparziale (a proposito dei rapporti tra 'politica' e 'amministrazione'), en Dir. pubbl., 1997, pp. 319 ss., en particular pp. 349-367; P. Forte, II principio di distinzione tra politica e amministrazione, cit., pp. 104 ss. En la amplísima bibliografía sobre las autoridades independientes, véase al menos, en la última década, F. Merusi, Democrazia ed autorità indipendenti: un romanzo "quasi" giallo, Bolonia, II Mulino, 2000; F.A. Grassini (encargado), L'indipendenza delle autorità, Bolonia, II Mulino, 2001; P. Lazzara, Autorità indipendenti e discrezionalità, Padua, Cedam, 2002 ; F. Merusi - M. Passaro, capítulo Autorità indipendenti, en Enc. dir., Aggiornamento, vol. VI, Milán, Giuffré, 2002, pp. 143 ss.; F. Merusi - M. Passaro, Le autorità indipendenti. Un potere senza partito, Bolonia, II Mulino, 2003; N. Longobardi, Autorità amministrative indipendenti e sistema giuridico-istituzionale, Turín, Giappichelli, 2004; M. Clarich, Autorità indipendenti: bilancio e prospettive di un modello, Bolonia, II Mulino, 2005; G. Grasso, Le autorità amministrative indipendenti della Repubblica: tra legittimità costituzionale e legittimazione democratica, Milán, Giuffrè, 2006; M. Zuppetta, Le autorita amministrative indipendenti: modello superato o consolidato?, Nápoles, ESI, 2005; M. De Benedetto, capítulo Autorità indipendenti, en S. Cassese (diretto da), Dizionario di diritto pubblico, cit., vol. I, pp. 588 ss.; M. Cuniberti, Autorità indipendenti e libertà costituzionali, Milán, Giuffré, 2007; M. Manetti, Le autorità indipendenti, Roma, Laterza, 2007; A. Police, Tutela della concorrenza e pubblici poteri. Profili di diritto amministrativo nella disciplina antitrust, en F.G. Scoca - G. Morbidelli - F. Ro- 
Es preciso partir de que el modelo de la separación, a diferencia del de la distinción, conlleva el corte, al menos tendencial, de cualquier vínculo entre la orientación política y la actividad administrativa, que llegaría a estar totalmente desvinculada de la primera hasta convertirse en autocéfala. La sustracción de las autoridades independientes a cualquier forma de orientación política plantea, según muchos autores, problemas de compatibilidad con el principio democrático: de hecho, este último exigiría que se garantizasen momentos de responsabilidad política, directa o indirecta, al menos en última instancia, ante el cuerpo electoral por no haber alcanzado los objetivos de la acción administrativa. Bajo esta perspectiva, tan numerosos como variados han sido los esfuerzos argumentativos realizados por otros estudiosos para intentar conciliar la posición institucional de las autoridades independientes con el cuadro constitucional y, en especial, para que éstas recuperen legitimación en el plano del respeto del principio democrático ${ }^{63}$.

En este contexto entra en juego el problema más específico de la relación entre principio de imparcialidad según el art. 97 Const. y el fenómeno de las autoridades independientes.

Surgen en la doctrina al menos dos tesis contrapuestas al respecto.

Según una primera tesis, sería el principio de neutralidad el que connotaría a las autoridades independientes, que implicaría (en el ámbito institucional) indiferencia e imparcialidad de tercero con respecto a los intereses en juego, con la asunción de una posición de alguna forma similar a la del juez, y equivaldría (en el ámbito funcional) a un rol de garantía y/o regulación condicional.

Abundando en esta tesis, los principios de neutralidad e independencia resultarían, cualitativamente y no solo cuantitativamente, diferentes del principio de imparcialidad que se aplica a las administraciones públicas ordinarias.

De hecho, la imparcialidad ve a la administración pública ya no en posición arbitral, neutral e indiferente de "tercero", sino como "parte imparcial" (sobre la base de la citada definición de Allegretti), dado que es portadora de un interés público prima-

\footnotetext{
versi Monaco (dir.), Sistema del diritto amministrativo italiano, Turín, Giappichelli, 2007; A. Valastro, Le autorità indipendenti in cerca di interlocutore, Nápoles, ESI, 2008; A. La Spina - S. Cavatorto, Le autorità indipendenti, Bolonia, II Mulino, 2008; M. Foglia, I poteri normativi delle autorità amministrative indipendenti, en Quad. reg., 2008, pp. 559 ss.; M. Pierri, Autorità indipendenti e dinamiche democratiche, Padua, Cedam, 2009; G. Napolitano - A Zoppini, Le autorità al tempo della crisi: per una riforma della regolazione e della vigilanza sui mercati, Bolonia, Il Mulino, 2009; M. D’Alberti - A. Pajno (encargado), Arbitri dei mercati. Le autorità indipendenti e l'economia, Bolonia, II Mulino, 2010; G.P. Cirillo - R. Chieppa (encargado), Le autorità amministrative indipendenti, en G. Santaniello (director), Trattato di diritto amministrativo, Padua, Cedam, 2010.

63 Para una reseña tanto de las opiniones que muestran perplejidad en cuanto a la compatibilidad de las autoridades independientes con el marco constitucional actual, como de las propuestas doctrinales dirigidas a demostrar, por diversas vías, dicha compatibilidad, véase M. Cuniberti, Autorità indipendenti e libertà costituzionali, cit., en particular pp. 50 ss., 405 ss. e 485 ss.; A. Police, Tutela della concorrenza e pubblici poteri, cit., pp. 137 ss.; C. Franchini - G. Vesperini, L'organizzazione, en S. Cassese (encargado), Istituzioni, cit., pp. 98 ss.
} 
rio que se ha de compaginar con los demás intereses en juego; bajo esta perspectiva, la imparcialidad se relaciona con un papel de gestión concreta y de administración activa, aplicando la orientación política y administrativa por parte de los órganos democráticamente legitimados y políticamente responsables, por lo que no se puede confundir con la independencia de la orientación política ${ }^{64}$.

Según otro planteamiento, en cambio, el modelo de la separación entre política y administración encarnado por la autoridades independientes sería, en todo caso, expresión del principio de imparcialidad según el art. 97 Const., aunque en un grado de intensidad más elevado con respecto al ordinario ${ }^{65}$.

64 La diferenciación entre neutralidad/independencia e imparcialidad administrativa, en los términos expuestos en el texto, ha sido defendida por V. Caianiello, Le autorità indipendenti tra potere politico e società civile, en Foro amm., 1997, pp. 341 ss., en particular pp. 368 ss. [ahora publicado de nuevo en Id., Istituzioni e liberalismo (a cargo de F. Cintioli), Soveria Mannelli, Rubbettino, 2005, pp. 115 ss.] y ha sido retomada por muchos Autores posteriores, entre los cuales, recientemente, E. Casetta, Manuale di diritto amministrativo, cit., p. 252; G.P. Cirillo - R. Chieppa, Introduzione, en Id. (encargado), Le autorità amministrative indipendenti, cit., pp. 27 ss.; S. Miconi, I contratti dei servizi pubblici, Assago, Cedam, 2010, pp. $22-23$. Ya se ha subrayado cómo la imparcialidad administrativa que trata el art. 97 Const. no se puede reducir a los caracteres de imparcialidad de tercero e indiferencia ante los intereses en juego que, sin embargo, connotan la imparcialidad del juez: véanse en tal sentido las posiciones de Benvenuti y Forte que se tratan en la anterior nota 55; recientemente, también A. Cerri, Istituzioni di diritto pubblico, cit. p. 273; A. Barbera - C. Fusaro, Corso di diritto pubblico, Bolonia, II Mulino, 2010, p. 381. Según otra opinión, la neutralidad se diferenciaría de la imparcialidad por la ausencia del carácter de discrecionalidad: en este sentido, por ejemplo, véase L. Torchia, Gli interessi affidati alla cura delle Autorità indipendenti, en C. Franchini - S. Cassese (encargado), I garanti delle regole, Bolonia, II Mulino, 1996, en particular p. 59.

65 Véase G. Greco, Argomenti di diritto amministrativo. Parte generale. I lineamenti essenziali del sistema, Milán, Giuffré, 2010, según el cual las autoridades independientes representarían "una feliz aplicación de los principios constitucionales de buen desarrollo y de imparcialidad (art. 97, c. 1, Const.)" (op. cit., p. 30) y actuarían en posición de "imparcialidad separada" (allí, p. 31). Según C. Franchini - G. Vesperini, L'organizzazione, en S. Cassese (encargado), Istituzioni, cit., p. 82, “el principio de independencia resulta ser muy similar al de imparcialidad”. La tesis según la cual las autoridades independientes se deberían remitir al principio de imparcialidad que trata el art. 97 Const. representando una acentuación de su grado, se encuentra de nuevo, por ejemplo, en A. Massera, "Autonomia" ed "indipendenza" nell'amministrazione dello Stato, en Aa.Vv., Scritti in onore di Massimo Severo Giannini, vol. III, Milán, Giuffré, 1988, p. 453 e pp. 479 ss.; N. Longobardi, Autorità amministrative indipendenti e sistema giuridico-istituzionale, cit., pp. 3-4, 21 ss., 60 ss., 102 (nótese que el Autor, aunque remitiendo expresamente las autoridades independientes al seno del principio de imparcialidad que trata el art. 97 Const., al mismo tiempo [p. 99] se adhiere a la tesis de la "posición de la neutralidad, o bien de indiferencia con respecto a los intereses" en la que se encontrarían las autoridades independientes, añadiendo [p. 101] que "la ecuación neutralidad = apoliticidad es puramente falsa. Neutralidad significa solo indiferencia con respecto a los intereses en juego"); R. Caranta, Art. 97, cit., p. 1897; M. Cuniberti, Autorità indipendenti e libertà costituzionali, cit., pp. 488-495 (según el A. [p. 489], las autoridades independientes responderían a la "necesidad de asegurar al máximo grado la imparcialidad administrativa en áreas en las que el reequilibrio de las posiciones económicas requiere intervenciones particularmente invasivas con respecto a la autonomía privada"); G. Corso, Le norme costituzionali sull'organizzazione, cit., pp. 40-41 (el A. vincula el fenómeno al "modelo de imparcialidad reforzada" previsto en la Constitución para el Consejo de Estado y el Tribunal de Cuentas, y subraya cómo para las autoridades independientes "no basta, por tanto, la imparcialidad normal, es necesaria una independencia excepcional" porque "es necesario que la autoridad sea neutral en sumo grado"). Para M. Manetti, Le autorità indipendenti, cit., pp. 116-117,"la imparcialidad de las autoridades independientes” se distinguiría radicalmente de la "imparcialidad del juez, que también se define como imparcialidad de tercero con respecto a los intereses de las partes públicas o privadas del proceso ... consiste en la posición de absoluta indiferencia con respecto a la tutela y a la mejor realización de los intereses públicos, y está destinada a 
Algunos autores motivan dicha tesis rechazando de raíz la idea de que las autoridades independientes estén en una posición de neutralidad, imparcialidad de tercero e indiferencia asimilable a la del juez: al contrario, según dichos autores, se debería reconocer el hecho de que las autoridades independientes, al ser administraciones públicas, realizan valoraciones altamente discrecionales, ponderando intereses públicos y privados ${ }^{66}$, razón por la que debería regir el principio de imparcialidad según el art. 97 Const., en una versión reforzada y llevada al máximo grado de profundidad.

Otros autores se remiten a la teoría según la cual la Constitución italiana sería compatible con varios modelos de administración, por lo que el art. 95 Const. (que establece el principio de la responsabilidad política para el ejercicio de la actividad administrativa, garantizado por el reconocimiento por parte de los órganos democráticamente representativos del poder de orientación para con la administración) no debería necesariamente "hacer solo suyo" el art. 97 Const., que, al ensalzar el principio-valor de la imparcialidad administrativa, también haría compatible desde el punto de vista constitucional un modelo alternativo de administración "autocéfala", sustraída a la influencia política, como es el encarnado actualmente, par excellence, justamente por las autoridades independientes ${ }^{67}$.

Obviamente, ambas orientaciones opuestas se pueden o no compartir según la diferente interpretación que en cada caso se haga del fenómeno de las autoridades independientes, de su papel y de sus funciones ${ }^{68}$.

asegurar la aplicación exclusiva de la ley (y de la Constitución)"; al mismo tiempo, sin embargo, las autoridades independientes se caracterizarían por "una imparcialidad que, a diferencia de la de la administración pública tradicional, no es de naturaleza apolítica, sino que se deriva (o se debería derivar) de una politicidad bipartisan o "ultramayoritaria"”.

66 Para la crítica estrictamente ceñida a la "utopía" o "mito" de la neutralidad de las autoridades independientes, véase por ejemplo M. Manetti, Le autorità indipendenti, cit., pp. 23 ss.; M. Cuniberti, Autorità indipendenti e libertà costituzionali, cit., en particular pp. 405-416; A. Police, Tutela della concorrenza e pubblici poteri, cit., en particular pp. 67, 127 ss., 246, 250.

67 Así, por ejemplo, A. Massera, "Autonomia” ed "indipendenza” nell'amministrazione dello Stato, cit., pp. 479 ss.; N. Longobardi, Autorità amministrative indipendenti e sistema giuridico-istituzionale, cit., p. 55 e pp. 61 ss.; M. Cuniberti, Autorità indipendenti e libertà costituzionali, cit., pp. 490 ss. Todos los autores citados aluden, como supuesto, a la conocida tesis propuesta por M. Nigro, La pubblica amministrazione fra Costituzione formale e Costituzione materiale, en Riv. trim. dir. proc. civ., 1985, pp. 162 ss., ahora en Id., Scritti giuridici, Tomo III, Milán, Giuffré, 1996, pp. 1845 ss., según la cual habría que distinguir tres modelos de administración que estarían presentes en la Constitución, a saber: "la administración como aparato al servicio del gobierno" (art. 95 Const.); la "administración como aparato autónomo, separado del gobierno y en general del poder político ... no subordinado al poder político, sino regulado directamente por la ley ... una burocracia que se autorregula: una administración imparcial gestionada por empleados al servicio de la Nación ... la administración come complejo autocéfalo" (arts. 97 y 98 Const.); en definitiva, "una administración autonomista y comunitaria ... que, además, no presenta municipios, provincias y regiones (y otras entidades locales), sino que consiste en ellos, y si se acepta la tesis expansiva de esta voluntad autonomista, consiste no tanto en las entidades sino precisamente en las comunidades" (art. 114 e ss. Const.); observaba Nigro que "entonces debemos aceptar la idea de que en nuestra Constitución coexisten institucionalmente los tres modelos en su diversidad y conflictualidad, y que las tensiones entre ellos son, siempre para la Constitución, eventos no patológicos, sino fisiológicos (al menos dentro de ciertos límites)".

68 Para eludir la polaridad absolutizante de las dicotomías parece que se puede compartir la posición equilibrada según la cual "los órganos de gobierno... en virtud del principigo democrático son los 


\section{3. (sigue) El principio de la participación procedimental. Integridad y pertinencia de la instrucción y valoración. Motivación obligatoria de la medida final}

El principio -genus de imparcialidad se puede considerar el generador de un principio-species que permea de por sí toda la legislación administrativa, es decir, el principio de la participación procedimental.

De hecho, según la opinión que prevalece, la necesidad de que la medida esté precedida de un procedimiento administrativo abierto a la participación de los ciudadanos -ya se desarrolle esta última en clave de "defensa" por la administración pública (participación con finalidad de garantía) o en clave de "ayuda" (participación colaborativa)- emana del principio constitucional de imparcialidad en su dimensión positiva e inclusiva (véase retro, par. 3.1.) ${ }^{69}$.

A menudo se utiliza al respecto, en la doctrina y en jurisprudencia, la locución "principio del justo procedimiento administrativo", a la que sin embargo se atribuyen significados no siempre coincidentes ${ }^{70}$.

responsables últimos de la administración en sus relaciones con la colectividad popular o del cuerpo electoral. Las propias administraciones independientes, en virtud del mismo principio, desde luego deben actuar, dada la naturaleza de las funciones ejercidas por ellas, de forma totalmente separada de condicionamientos del poder político. Además, al mismo tiempo deben existir mecanismos de vinculación y de coordinación con el poder político que reconduzcan también a las administraciones independientes al circuito conjunto de aplicación del principio democrático mismo": así G. Pastori, Prospettive attuali del diritto amministrativo, en G. Palma (encargado), Lezioni. Corso di perfezionamento in Amministrazione e finanza degli Enti locali: anno accademico 2005-2006, Nápoles, ESI, 2007, pp. 400-401.

69 D. Sorace, Diritto, cit., pp. 350-352. En sentido análogo, además de los otros Autores citados en la anterior nota 55, véase G. Pastori, La procedura amministrativa negli ordinamenti contemporanei. Introduzione generale, en Id. (encargado), La procedura amministrativa, cit., en particular pp. 64-65; U. Allegretti, L'imparzialità amministrativa, cit., passim; Id., capítulo Imparzialità e buon andamento della pubblica amministrazione, en Dig. disc. pubbl., Turín, Utet, 1993, p. 135; G. Barone, L'intervento del privato nel procedimento amministrativo, cit., pp. 54 ss. e 171 ss.; A. Cerri, Imparzialità, cit., pp. 128 ss.; G. Sala, Imparzialità dell'amministrazione e disciplina del procedimento nella recente giurisprudenza amministrativa e costituzionale, cit., pp. 433 ss.; Id., Il principio del giusto procedimento, cit., pp. 104 ss.; A. Pubusa, Considerazioni sull'imparzialità amministrativa nella L. 7 agosto 1990, n. 241 , en Aa.Vv., Scritti in onore di Pietro Virga, Tomo II, Milán, Giuffré, 1994, pp. 1437 ss.; G. Palma, Itinerari di diritto amministrativo (Lezioni 1993-1994), Padua, Cedam, 1996, pp. 280 ss.; G. Corso, L'attività amministrativa, Turín, Giappichelli, 1999, pp. 88-89; Id., Manuale di diritto amministrativo, Turín, Giappichelli, 2008, p. 362; A. Sandulli, Il procedimento, en S. Cassese (encargado), Trattato di diritto amministrativo. Diritto amministrativo generale, Tomo II, Milán, Giuffré, 2000, p. 967; S. Cognetti, Procedura amministrativa, cit., pp. 234-235; G. Morbidelli, Introduzione all'attività amministrativa e Il procedimento amministrativo, ambos en Aa.Vv., Diritto amministrativo. I. Parte generale, Bolonia, Monduzzi, 2005, respectivamente p. 528 y pp. 636-639; G. Rossi, Diritto amministrativo. I. Principi, cit., p. 132. Según M. Nigro, II procedimento amministrativo fra inerzia legislativa e trasformazioni dell'amministrazione (a proposito di un recente disegno di legge), en Dir. proc. amm., 1989, pp. 5 ss., ahora en Id., Scritti giuridici, cit., Tomo III, pp. 2037 ss., el procedimiento administrativo sería (p. 2039) "instrumento de mediación entre la finalidad de garantía (la imparcialidad) y la finalidad de buena administración (realización de la eficacia)", en donde "la amplia participación, el complejo entrelazamiento de los intereses y los hechos, y la cuidadosa instrucción que enriquecen y dan vida al procedimiento sirven no solo para garantizar la más escrupulosa imparcialidad, sino para hacer posible la elección más adecuada".

70 Subraya la pluralidad de significados, en el actual uso de la doctrina, de la locución "justo procedimiento" V. Cerulli Irelli, Lineamenti, cit., pp. 307-309. véase también U. Allegretti, Procedura, procedimen- 
En un primer significado, el principio del justo procedimiento administrativo se refiere al problema de la existencia de una "reserva de función administrativa" con respecto a la delicada relación entre legislación y administración $n^{71}$ : el problema refleja el discutido fenómeno de las leyes-medida, es decir, de la asunción en forma de ley de elecciones, en sustancia, de naturaleza administrativa, porque son puntuales y concretas en vez de generales y abstractas, las cuales se realizan ante acontecimientos determinados "saltándose", precisamente por causa del recurso a la forma de la ley, el desarrollo de un procedimiento administrativo participado y haciendo inaccesibles los caminos de tutela ante el juez administrativo ${ }^{72}$.

En un segundo significado, el principio del procedimiento administrativo justo se entiende en sentido restringido, dado que se refiere solo a la participación con objeto de garantía73, en clave de tutela con respecto a procedimientos administrativos de signo desfavorable ${ }^{74}$, coincidiendo con lo que se ha definido como el "derecho de defensa en el procedimiento administrativo"75.

Finalmente, en sentido más amplio, el principio del justo procedimiento coincide con todo el ámbito del principio de participación procedimental, independientemente de los fines y las direcciones de esta última (defensa o colaboración) ${ }^{76}$.

to, processo. Un'ottica di democrazia partecipativa, en Aa.Vv., Procedura, procedimento e processo, cit., p. 24 , nota 18 .

71 D. Vaiano, La riserva di funzione amministrativa, Milán, Giuffré, 1996. Sobre este tema, más recientemente, y también para las referencias bibliográficas a las numerosas contribuciones sobre el tema, S. Spuntarelli, L'amministrazione per legge, cit.

72 Entre los autores que entienden el principio del justo procedimiento en este sentido véase, por ejemplo, G. Corso, L'attività amministrativa, cit., pp. 87-88; Id., Manuale di diritto amministrativo, Turín, Giappichelli, 2010, pp. 216-217; E. Casetta, Manuale, cit., p. 47. Sobre las relaciones entre "reserva de procedimiento administrativo" y "principio del justo procedimiento" véanse también las reflexiones de G. Manfredi, Giusto procedimento e interpretazioni della Costituzione, en Aa.Vv., Procedura, procedimento e processo, cit., pp. 93 ss., en particular pp. 109-112.

73 De hace poco, véanse las observaciones al respecto de M. Bellavista, Giusto processo come garanzia del giusto procedimento, en Aa.Vv., Procedura, procedimento e processo, cit., pp. 249 ss., en particular pp. 287 ss.

74 Para este significado restringido, que contrapone el principio del justo procedimiento o principio del contradictorio (relativo solo a los procedimientos que desemboquen en medidas limitativas para los destinatarios) al principio de participación (relativo a todos los procedimientos), véase como ejemplo S. Fantini, La partecipazione al procedimento e le pretese partecipative, en B. Cavallo (encargado), II procedimento amministrativo tra semplificazione partecipata e pubblica trasparenza, Turín, Giappichelli, $2000, \mathrm{p}$. 87; M. Clarich, Garanzia del contraddittorio nel procedimento, en Dir. amm., 2004, p. 74; M. De Benedetto, Istruttoria amministrativa e ordine del mercato, Turín, Giappichelli, 2008, pp. 56 ss e pp. 77 ss.; B.G. Mattarella, Il procedimento, en S. Cassese (encargado), Istituzioni, cit., p. 249.

75 A. Scognamiglio, I/ diritto di difesa nel procedimento amministrativo, Milán, Giuffré, 2004.

76 Para este uso en sentido más amplio de la locución “justo procedimiento" véase, siempre a título de ejemplo, G. Roehrssen, I/ giusto procedimento nel quadro dei principi costituzionali, en Aa.Vv., La disciplina generale del procedimento amministrativo. Contributi alle iniziative legislative in corso (Actas del XXXII Convegno di studi di scienza dell'amministrazione, Varenna-Villa Monastero, 18-20 de septiembre de 1986), Milán, Giuffrè, 1989, p. 62 e pp. 67 ss. (el mismo Autor, en las pp. 92-95, saca a la luz el vínculo inseparable entre el principio del justo procedimiento y el principio constitucional de imparcialidad); P.M. Vipiana, L'autolimite della pubblica amministrazione. L'attività amministrativa fra coerenza e flessibilità, Milán, Giuffrè, 1990, pp. 225 (la cual subraya cómo "el así llamado principio del justo procedimiento ... constituye 
La correlación entre imparcialidad y justo procedimiento administrativo, incluso en caso de que este último se entienda en la acepción restringida de participación “defensiva”, es apoyada por la opinión doctrinal que prevalece77, aunque otras opiniones remitan el principio del justo procedimiento a disposiciones constitucionales diferentes del art. 97 Const. al hacer referencia, por ejemplo, por la analogía existente entre el procedimiento administrativo y el proceso jurisdiccional, a las disposiciones establecidas en el art. 24 Const. (derecho de defensa en el proceso $)^{78}$ y el art. 111 Const. (principio del justo proceso) ${ }^{79}$. Además hay quien, bajo una perspectiva aún diferente, auspicia el anclaje unitario del principio de participación en el art. 3, párrafo 2, Const. (principio de igualdad en sentido sustancial ${ }^{80}$ ) para superar la dicotomía entre la referencia al art. 97 Const. (que según esta tesis fundamentaría la participación en clave colaborativa) y la referencia al art. 24 Const. (que, también según esta opinión, fundamentaría la participación en clave defensiva) $)^{81}$.

El Tribunal constitucional, a pesar de algunas vacilaciones pasadas, en los últimos lustros parece reconocer progresivamente el rango constitucional del principio del justo procedimiento (aunque tienda, más veces, a limitarlo a la acepción restringida de participación de garantía ${ }^{82}$ ) y, sobre todo, parece valorar su vínculo, sobre el

la síntesis verbal entre dos instituciones conexas ... por un lado, la participación procedimental con fines de colaboración ... por otro lado, el contradictorio administrativo, con fines principalmente defensivos"); véase también A. Zito, il procedimento amministrativo, en F.G. Scoca (encargado), Diritto amministrativo, Turín, Giappichelli, 2008, pp. 223-224.

77 Véanse los Autores citados en la anterior nota 69.

78 Para esta tesis véase, recientemente, L. De Lucia, Provvedimento amministrativo e diritti dei terzi. Saggio sul diritto amministrativo multipolare, Turín, Giappichelli, 2005, en particular pp. $19 \mathrm{ss}$. y también las notas 33 y 34; Id., Procedimento amministrativo e interessi materiali, en Dir. amm., 2005, pp. 119-20, note 86 e 87. Véase también A. Scognamiglio, I/ diritto di difesa nel procedimento amministrativo, cit., passim, pero, en particular, p. 12, nota 35 y pp. 52 ss. y las observaciones críticas de M.T. Serra, Contributo ad uno studio sulla istruttoria del procedimento amministrativo, Milán, Giuffré, 1991, pp. 214 ss.

79 L. Buffoni, Alla ricerca del principio costituzionale del "giusto procedimento": la "processualizzazione" del procedimento amministrativo, en A. Massera (encargado), Le tutele procedimentali. Profili di diritto comparato, Nápoles, Jovene, 2007, pp. 189 ss., en particular pp. 206-207 y pp. 210 ss.; S. Mangiameli, "Giusto procedimento" e "giusto processo". Considerazioni sulla giurisprudenza amministrativa tra il modello dello Stato di polizia e quello dello Stato di diritto, en http://www.rivistaaic.it, 2010.

80 El art. 3, párrafo 2, Const., reza: “Es tarea de la República eliminar los obstáculos de orden económico y social que, limitando de hecho la libertad y la igualdad de los ciudadanos, impiden el pleno desarrollo de la persona y la efectiva participación de todos los trabajadores en la organización política, económica y social del País".

81 En este sentido A. Zito, La partecipazione ai procedimenti amministrativi: considerazioni minime sul fondamento costituzionale, en Aa.Vv., Procedura, procedimento e processo, cit., pp. 181 ss., en particular pp. 186-191: el Autor se remite, apoyándolas, a las opiniones expresadas sobre la valoración del art. 3, párrafo 2, Const., en cuanto al fundamento constitucional de la participación procedimental, por U. Allegretti, L'amministrazione dall'attuazione costituzionale alla democrazia partecipativa, Milán, Giuffré, 2009, p. 286 y también por A. Pubusa, Procedimento amministrativo e interessi sociali, Turín, Giappichelli, 1988.

82 Reconstruye de forma completa la evolución de la jurisprudencia del Tribunal Constitucional en el tema del “justo procedimiento" P. Lazzara, L'azione amministrativa ed il procedimento in cinquant'anni di giurisprudenza costituzionale, en G. Della Cananea-M. Dugato (encargado), Diritto amministrativo e Corte costituzionale, Nápoles, ESI, 2006, pp. 387 ss., en particular pp. 396 ss. 
plano del fundamento constitucional, con el principio de imparcialidad indicado en el art. 97 Const. en la dimensión organizativa ${ }^{83}$ y en la dimensión funcional ${ }^{84}$.

La participación procedimental es defendida, en concreto, por numerosas normas de derecho positivo contenidas en la ley general sobre el procedimiento administrativo, entre las que figuran la obligación de comunicación del inicio del procedimiento, el derecho de los interesados a intervenir en el procedimiento y presentar memorias y observaciones, la obligación de previa comunicación de los motivos que impiden la aceptación de la instancia del particular o del "preaviso de desestimación" (artículos del 4 al 10-bis de la L. 241/1990) ${ }^{85}$.

También se vinculan al principio de participación procedimental y, por tanto, encuentran fundamento constitucional en la imparcialidad los ulteriores principios de la integridad y la pertinencia de la instrucción y la valoración en el seno del procedimiento administrativo. En virtud de dichos principios, los órganos administrativos encargados de la instrucción y decisión deben llegar a conocer, comprobar y valorar íntegramente todos los hechos y los intereses pertinentes ${ }^{86}$, en la medida en que sean significativos para el interés público concreto que se ha de satisfacer, de forma que permitan conocer y ponderar lo más completa y precisamente posible los diversos aspectos del caso ${ }^{87}$.

Finalmente, parece que se puede compartir la opinión, presente en una parte de la doctrina, que remite al principio constitucional de imparcialidad también la obligación de motivar las medidas administrativas, hoy traspuesto en el art. 3 de la L. $241 / 1990^{88}$, también sobre la base del argumento por el que la motivación obligato-

83 En este sentido, Tribunal Const., 22 de julio de 2011, n. ${ }^{\circ} 228$ (punto 3.1.); Tribunal Const., 5 de marzo de 2010, n. ${ }^{\circ} 81$ (punto 6.2.); Tribunal Const., 5 de febrero de 2010, n. ${ }^{\circ} 34$ (punto 7); Tribunal Const., 28 de noviembre de 2008, n. $^{\circ} 390$ (puntos 6.3 y 6.4.1.); Tribunal Const., 24 de octubre de 2008, n. ${ }^{\circ} 351$ (punto 2); Tribunal Const., 20 de mayo de 2008, n. 161 (punto 3.3.); Tribunal Const., 23 de marzo de 2007, n. 104 (puntos 2.10. y 5); Tribunal Const., 23 de marzo de 2007, n. ${ }^{\circ} 103$ (punto 9.2.). Todas estas sentencias afectan a la problemática del spoils system, para la cual véase retro, en la anterior nota 61.

84 Tribunal Const., 26 de mayo de 1994, n. ${ }^{\circ} 197$ (punto 2); Tribunal Const., 5 de febrero de 1992, n. ${ }^{\circ}$ 37 (punto 3); Tribunal Const., 18 de enero de 1991, n. ${ }^{\circ} 17$ (punto 3).

85 La literatura sobre estas instituciones es muy amplia. Por ello nos limitamos a citar, también por las necesarias referencias bibliográficas, las recientes contribuciones de R. Proietti, La partecipazione al procedimento amministrativo, M. Ramajoli, L'intervento nel procedimento, P. Chirulli, I diritti dei partecipanti al procedimento e D. Vaiano, I/ preavviso di rigetto, todos en M.A. Sandulli (encargado), Codice dell'azione amministrativa, cit., respectivamente en las pp. 484 ss., 516 ss., 528 ss. y 549 ss.

86 Sobre la noción de "pertinencia" y sobre las relaciones de dicha noción con la de "relevancia", véase S. Cognetti, 'Quantità' e 'qualità' della partecipazione. Tutela procedimentale e legittimazione processuale, Milán, Giuffré, 2000, pp. 74 ss.; anteriormente, en sentido distinto, F. Ledda, Problema amministrativo e partecipazione al procedimento, en Dir. amm., 1993, pp. 133 ss., en particular p. 145.

87 U. Allegretti, L'imparzialità, cit., passim pero, en particular, pp. 27 ss., 193 ss. e 228 ss.; G. Sala, Potere amministrativo e principi dell'ordinamento, Milán, Giuffrè, 1993, pp. 172 ss.; G. Palma, Itinerari, cit., pp. 276 ss.; G. Corso, L'attività amministrativa, cit., pp. 34-35; L.R. Perfetti, Amministrazione pubblica e diritto amministrativo, cit., pp. 15-16; G. Morbidelli, Stato democratico e modelli di amministrazione, cit., p. 224; R. Chieppa - R. Giovagnoli, Manuale di diritto amministrativo, Milán, Giuffré, 2011, p. 326.

88 A. Cerri, Imparzialità, cit., pp. 136-137 y allí nota 65; R. Iannotta, La motivazione come modo di attuazione del principio di imparzialità amministrativa, en Aa.Vv., Scritti in onore di Costantino Mortati, vol. 
ria del acto final es expresión del principio de trasparencia, que, a su vez, constituye una aplicación del principio de imparcialidad ${ }^{89}$ (véase infra, párrafo 3.4).

De hecho, la obligación de motivación es garantía imprescindible para asegurar la efectividad de los principios de participación procedimental y de integridad y pertinencia de la instrucción y valoración y, por tanto, para traducir la imparcialidad "positiva” desde el plano del derecho proclamado hasta el del derecho practicado.

Es necesario precisar este punto. La doctrina ha subrayado la relación de "simetría" entre participación, instrucción y motivación: si el primero de los tres términos se contrae o expande, de forma correspondiente se produce una contracción o una expansión de los otros dos términos ${ }^{90}$.

II, Giuffrè, Milán, 1977, pp. 197 ss.; U. Allegretti, capítulo Imparzialità e buon andamento della pubblica amministrazione, cit., p. 135; F. Benvenuti, Disegno, cit., p. 239; G. Morbidelli, Introduzione all'attività amministrativa, cit., p. 528; R. Chieppa - R. Giovagnoli, Manuale, cit., p. 326.

89 A.M. Sandulli, Manuale di diritto amministrativo, vol. I, Nápoles, Jovene, 1984, p. 673; L.R. Perfetti, Amministrazione pubblica e diritto amministrativo, cit., pp. 15-16; B.G. Mattarella, Il provvedimento, en S. Cassese (encargado), Istituzioni, cit., p. 249; E. Casetta, Manuale, cit., p. 53 e p. 417; D. Sorace, Diritto, cit., p. 70.

90 Para esta relación de "simetría", véase (también para la exposición de las diversas posiciones de la doctrina acerca del fundamento, los contenidos y los límites de la obligación de motivación) la reciente contribución actualizada de F. Cardarelli, La motivazione del provvedimento, en M.A. Sandulli (encargado), Codice dell'azione amministrativa, cit., pp. 300 ss., en particular pp. 337-338, 356, 360, 392. El autor (pp. 337-338) observa que "dado que la fase de la cognición está asegurada en el procedimiento de la instrucción, y se trata de una instrucción cualificada abierta a la participación procedimental ... instrucción, participación procedimental y motivación son simétricos y especulares, y se implican recíprocamente", en donde la motivación es "elemento formal del acto, pero reflejo sustancial del procedimiento". El mismo autor indica que una "prueba" de dicha relación de simetría (entre la instrucción abierta a la participación y la obligación demotivación) se encuentra en la L. 241/1990, en cuanto que el ámbito de los procedimientos para los cuales se ha previsto (en el art. 13, párrafo 1) una exoneración de la disciplina general sobre la participación (en particular, los procedimientos relativos a los actos normativos y a los actos administrativos generales) coincide sustancialmente con el ámbito de las disposiciones para las que se ha previsto (en el art. 3) una exoneración de la disciplina general sobre la obligación de motivación. Al mismo tiempo, el autor (pp. 392 ss.) subraya que, siempre que los actos normativos (piénsese en las leyes dispositivas) o los actos administrativos generales (piénsese en los planes urbanísticos) terminen por contener algunas prescripciones puntuales y concretas, capaces de incidir en destinatarios concretos, en estos supuestos las leyes especiales al respecto, los estatutos regionales y, además, la jurisprudencia constitucional y administrativa prescriben que también se extiendan a dichos procedimientos las garantías esenciales de la participación procedimental y de la motivación, extrayéndolas a partir del art. 97 Const.: esto confirma ulteriormente la simetría entre participación y motivación. Sobre este tema véase también la contribución de M. Cocconi, L'obbligo di motivazione degli atti amministrativi generali, en Riv. trim. dir. pubbl., 2009, pp. 707 ss. (y también Id., La partecipazione all'attività amministrativa generale, Padua, Cedam, 2010). La contribución, al registrar (p. 714) que "cada vez son más numerosos (y relevantes) los casos en los que la obligación de motivación está prevista también para los actos de contenido general, hasta el punto de tener que considerar que la obligación ya constituye la regla y la derogación es la excepción”, observa que (p. 721) “la motivación tiende ... a atenuar su valencia principalmente defensiva y a compartir, en parte, las mismas funciones de la participación, cuya efectividad debería garantizar”. Además (pp. 734-735), la autora destaca que "a través de la precisión de un vínculo necesario entre la instrucción y el contenido de la motivación, esta última contribuye, de hecho, a asegurar un realce sustancial y una mayor efectividad al ejercicio de la participación con respecto al contenido de la elección administrativa. De este modo, la motivación constituye una garantía de que, en la formación de la decisión, entre las razones de la elección administrativa se han considerado efectivamente los intereses representados en la instrucción administrativa por los suje- 
Esto es inevitable, porque se trata de tres subsistemas interdependientes de un mismo sistema jurídico: la imparcialidad.

Esta última, entendida en su sentido positivo e inclusivo, es ontológica y necesariamente una instrucción participada, abierta al diálogo con los sujetos de los intereses implicados para tomar la decisión y representan los hechos que éstos conocen: la imparcialidad no podría no ser esto sin negarse a sí misma.

La existencia debida de la imparcialidad es la posibilidad de que exista la participación.

Además, la motivación de la medida es el "resumen" de los resultados de la instrucción y se llena de contenidos sobre la base de la riqueza de esta última, haciendo visible el proceso de búsqueda y selección de las alternativas para las formas de fijación de los hechos surgidas de las manifestaciones de intereses de los participantes en el procedimiento ${ }^{91}$.

La motivación es el espejo de la “"“calidad” de la participación”: ésta expresa un “deber de reacción” de la administración pública ante la participación procedimental, es decir, una consecuencia necesaria de la participación entendida como "método -además de como medio o instrumento- de imparcialidad". De hecho, la administración que decide debe demostrar, a través de la motivación, que ha "tomado en consideración adecuadamente las circunstancias de hecho y de derecho que el participante ha presentado" y le ha hecho corresponder una "reacción administrativa de la que surjan con linealidad y claridad los criterios y las normas que hayan orientado la dinámica de la ponderación de los intereses". La motivación es "la respuesta definitiva a la cuestión de la pertinencia de los intereses manifestados... y a la cuestión ulterior de su sacrificabilidad" y "se extiende, obviamente, también a esos intereses (también ellos considerados pertinentes) que, al contrario de los sacrificados, se tutelen, pero en detrimento de otros intereses". En suma, la motivación destaca "la

tos privados", concluyendo (p. 740) en el sentido de que la obligación de motivación es "decisiva para incrementar la efectividad de las instancias participativas manifestadas en el curso del procedimiento y su posibilidad de incidir en la decisión administrativa". Además, Cocconi pone de manifiesto (p. 730) que la jurisprudencia del Tribunal Constitucional parece orientarse cada vez más en el sentido de que "subsista una obligación general de motivación de los actos administrativos de contenido general, también independientemente de previsiones normativas explícitas"; el Consejo, de hecho, tiende a aplicar (pp. 727-729 y allí las notas 56 e 57) “directamente los principios sobre el procedimiento de rango constitucional” y, en particular, el "principio del justo procedimiento ... entendido por la doctrina en su significado más amplio, o sea incluyendo en él también condiciones preventivas y sucesivas de ejercicio de la participación procedimental, tales como la comunicación de la tramitación, el acceso a las actuaciones y la motivación”, por el propio Tribunal Constitucional recientemente "remitido ... directamente a la realización del principio constitucional de imparcialidad” en la sentencia n. ${ }^{\circ}$ 103/2007 (para esta última véase retro, en la anterior nota 83).

91 Según el planteamiento del estudio fundamental de E. Cardi, La manifestazione di interessi nei procedimenti amministrativi, I y II, Rimini, Maggioli, 1983-1984, passim (pero véase, en particular, vol. I, pp. 92 ss. e vol. II, pp. 126 ss.), en el que se ha inspirado ampliamente la doctrina posterior (véase por ejemplo, entre las obras más recientes, A. Romeo, L'impugnabilità degli atti amministrativi, Nápoles, ESI, 2008, en particular pp. 360 ss.). 
importancia y el valor del contexto de justificación de la elección administrativa, tanto en relación con la selección de los intereses que entran a formar parte del material de ponderación como en relación con el resultado de la ponderación final”92.

Si es así, entonces el lícito afirmar que la motivación es la forma de la participación, su epifanía necesaria: que no puede existir garantía de la participación sin garantía de la motivación.

Dado que la imparcialidad "positiva" no puede prescindir de la participación, la obligación de motivación es coesencial e inherente al circuito de la imparcialidad.

Al afirmar esto no se pretende negar el hecho de que la instrucción, la participación y la motivación denoten un carácter polifuncional: de hecho, éstas se vinculan también a principios diferentes del de la imparcialidad.

En especial están vinculadas a la mejora de la eficacia de la acción administrativa y a la consecución óptima del resultado por parte de la administración pública (principio de buena evolución de la administración); al control democrático por parte de la colectividad (principio democrático); al derecho del ciudadano de tutelarse eficazmente en el ámbito jurisdiccional contrario a la medida (principio de justiciabilidad de la acción administrativa o accionabilidad); al orden del mercado (principio de tutela de la competencia); a la responsabilidad de la administración hacia los terceros y dentro de la organización (principio de responsabilidad), etc. ${ }^{93}$.

92 Las citas en el texto están extraídas de S. Cognetti, "Quantità" e "qualità" della partecipazione, cit., pp. 68, 69, 71 e 81 .

93 Para las diversas funciones desempeñadas por la instrucción, por la participación y por la motivación, y para su vínculo con los principios mencionados en el texto, nos remitimos a las contribuciones siguientes. Sobre la instrucción: M.T. Serra, Contributo ad uno studio sulla istruttoria del procedimento amministrativo, cit.; M. De Benedetto, Istruttoria amministrativa e ordine del mercato, cit.. Sobre la participación procedimental: S. Cognetti, 'Quantità' e 'qualità' della partecipazione, cit.; M. Occhiena, Situazioni giuridiche soggettive e procedimento amministrativo, Milán, Giuffré, 2002; M.R. Spasiano, La partecipazione al procedimento amministrativo quale fonte di legittimazione dell'esercizio del potere: un'ipotesi ricostruttiva, en Dir. amm., 2002, pp. 283 ss.; G. Barone, I modelli di partecipazione procedimentale, en V. Cerulli Irelli (encargado), II procedimento amministrativo, Nápoles, Jovene, 2007, pp. 132 ss.; S. Cassese, La partecipazione dei privati alle decisioni pubbliche. Saggio di diritto comparato, en Riv. trim. dir. pubbl., 2007, pp. 13 ss.; E. Chiti, La dimensione funzionale del procedimento, en Aa.Vv., Le amministrazioni pubbliche tra conservazione e riforme, Milán, Giuffrè, 2008, pp. 211 ss.; A. Zito, il procedimento amministrativo, cit.; A. Cardone, Procedimento amministrativo e partecipazione: giurisprudenza amministrativa e costituzionale e concezione dell'idea di giustizia, en Dir. pubbl., 2009, pp. 231 ss.; F. Satta, Contraddittorio e partecipazione nel procedimento amministrativo, en Dir. amm., 2010, pp. 299 ss. Sobre la motivación, además de los autores citados en las anteriores notas 88 hasta 90, véase M.S. Giannini, capítulo Motivazione dell'atto amministrativo, en Enc. dir., Milán, Giuffré, 1977, pp. 258 ss.; A. Romano Tassone, Motivazione dei provvedimenti amministrativi e sindacato di legittimità, Milán, Giuffrè, 1987; Id., capítulo Motivazione nel diritto amministrativo, en Dig. disc. pubbl., Appendice, Turín, Utet, 1997, pp. 683 ss. ; V. Mazzarelli, capítulo Motivazione dell'atto amministrativo, en Enc. giur., Roma, Treccani, 1990, pp. 1 ss.; A. Andreani, Idee per un saggio sulla motivazione obbligatoria dei provvedimenti amministrativi, en Dir. proc. amm., 1993, pp. 1 ss.; G. Corso, capítulo Motivazione dell'atto amministrativo, en Enc. dir., Aggiornamento, Milán, Giuffré, 2001, pp. 774 ss.; R. Villata - M. Ramajoli, Il provvedimento amministrativo, en Sistema del diritto amministrativo italiano dirigido por F.G. Scoca - F.A. Roversi Monaco 340 - G. Morbidelli, Turín, Giappichelli, 2006, pp. 248 ss.; F. Cardarelli, La motivazione del provvedimento, cit.; A 
En cuanto al principio de buen desarrollo y a los conceptos en los que se expresa, véase G. Falzone, Il dovere di buona amministrazione, Milán, Giuffré, 1953; N. Speranza, Il principio di buon andamento-imparzialità dell'amministrazione nell'art. 97 della Costituzione, en Foro amm., 1972, pp. 79 ss.; O. Sepe, L'efficienza nell'azione amministrativa, Milán, Giuffré, 1975; A. Andreani, Il principio costituzionale di buon andamento della pubblica amministrazione, Padua, Cedam, 1979; A. Saitta, II principio di buon andamento della Pubblica Amministrazione nella giurisprudenza costituzionale, en Dir. e soc., 1988, pp. 53 ss.; A. Costanzo, Collaborazione fra Stato e Regioni e buon andamento dell'amministrazione, en Giur. cost., 1988, pp. 815 ss.; S. Stammati, Il buon andamento dell'amministrazione: una rilettura e principi per un ripensamento (riattraversando gli artt. 95, $3 .{ }^{\circ}$ comma e 97, $1 .^{\circ}$ comma della Costituzione), en Aa.Vv., Scritti in onore di Massimo Severo Giannini, vol. III, cit., pp. 795 ss.; S. De Götzen, Interpretazione costituzionale, principio di buon andamento e individuazione giurisprudenziale del fondamento positivo del principio di leale collaborazione, en Le Regioni, 1992, pp. 705 ss.; G. D’Alessio, I/ buon andamento dei pubblici uffici, Ancona, CLUA, 1993; C. Pinelli, I/ "buon andamento" e l'"imparzialità" dell'amministrazione, en Commentario della Costituzione fundamentado por G. Branca y continuado por A. Pizzorusso, La pubblica amministrazione. Art. 97-98 Const. (a cargo de P. Caretti - C. Pinelli - U. Pototschnig - G. Long - G. Borrè), Bolonia - Roma, Zanichelli, 1994, pp. 31 ss.; M.R. Spasiano, L'organizzazione comunale: paradigmi di efficienza pubblica e buona amministrazione, Nápoles, ESI, 1995; M. Galdi, Buon andamento, imparzialità e discrezionalità amministrativa, cit.; G.M. Salerno, L'efficienza dei poteri pubblici nei principi dell'ordinamento costituzionale, Turín, Giappichelli, 1999; F. Longo, Collaborazioni tra enti locali nella logica dell'economicità dell'azione amministrativa, Milán, Giuffré, 2000; P.A. Capotosti, Legalità ed efficienza nell'amministrazione, en Rass. parl., 2001, pp. 869 ss.; L. Mercati, Responsabilità amministrativa e principio di efficienza, Turín, Giappichelli, 2002; P. Cerbo, Il principio di economicità nella nozione di impresa e nella pubblica amministrazione, en Foro it., 2003, pp. 332 ss.; D. Bolognino, Gli obiettivi di efficienza, di efficacia e di economicità nel pubblico impiego, Milán, Giuffré, 2004; S. Ricci, La buona amministrazione: ordinamento comunitario e ordinamento nazionale, Turín, Giappichelli, 2005; G. Bottino, I/ principio costituzionale di buon andamento e l'organizzazione "esterna" delle Pubbliche Amministrazioni: i limiti alla disciplina delle società regionali di servizi, en Giur. cost., 2005, pp. 2684 ss.; M. Cresti, Efficienza e garanzie nell'evoluzione dell'organizzazione statale, Milán, Giuffré, 2006; F. Midiri, Il principio di efficacia tra imparzialità e buon andamento nella legge di riforma del procedimento amministrativo $n^{\circ} 15$ del 2005, en Dir. econ., 2007, pp. 477-519 e pp. 671-720; A. Serio, II principio di buona amministrazione procedurale. Contributo allo studio del buon andamento nel contesto europeo, Nápoles, ESI, 2008; U. Comite - R. Rolli, Efficienza, efficacia ed economicità: "percorsi aziendali" per la Pubblica Amministrazione, en Giustizia amministrativa, 2008, pp. 326 ss.; L. Vandelli (encargado), Etica pubblica e buona amministrazione: quale ruolo per i controlli?, cit.; R. Scalia (encargado), Un contributo legislativo alla attuazione del principio costituzionale del "buon andamento" delle istituzioni pubbliche, nella XVI Legislatura, Roma, Istituto Max Weber, 2010; F.G. Grandis, La "riforma Brunetta" del lavoro pubblico. D.Igs. 27 de octubre de 2009, n. ${ }^{\circ} 150$. Luci ed ombre nella misurazione, valutazione e trasparenza della performance, en Giorn. dir. amm., 2010, pp. 23 ss.; G. Corsini, I controlli interni nella pubblica amministrazione dopo la riforma Brunetta, en Ragiusan, 2010, pp. 80 ss.; E. Villa, I/ sistema di misurazione-valutazione della performance dei dipendenti pubblici nel d.l.vo n. ${ }^{\circ} 150 \mathrm{del} 2009$, allí, 2010, pp. 228 ss.; Aa.Vv., La valutazione della performance dei funzionari pubblici, Bolonia, Il Mulino, 2010; R. Ruffini, L'evoluzione dei sistemi di controllo nella pubblica amministrazione. Linee operative per lo sviluppo dell'audit e della gestione delle performance nelle pubbliche amministrazioni, Milán, Franco Angeli, 2010; G. Soricelli, Considerazioni sulla Class action amministrativa nell'amministrazione di risultato, en Giustizia amministrativa, 2010, pp. 23 ss.; C. Deodato - M.G. Cosentino, L'azione collettiva contro la administración pública per l'efficienza dell'Amministrazione. Commento organico al decreto legislativo 20 de diciembre de 2009, $n .^{\circ} 198$, Roma, Nel Diritto, 2010; F. Manganaro, L'azione di classe in un'amministrazione che cambia, en www.giustamm.it, 2010; A.L. Tarasco, Amministrazione di qualità e controlli efficaci: un'endiadi possibile nella nuova “azione per l'efficienza"?, en Nuove autonomie, 2010, pp. 165 ss.; C.E. Gallo, La Class Action nei confronti della Pubblica Amministrazione, en Urb. app., 2010, pp. 501 ss.; R. Ferrara, L'interesse pubblico al buon andamento delle pubbliche amministrazioni: tra forma e sostanza, cit., pp. 31 ss.; I. Sigismondi, II principio del buon andamento tra politica e amministrazione, cit.; C. Tubertini, La prima applicazione della 'class action amministrati$v a$ ', en Giorn. dir. amm., 2011, pp. 862 ss.; C. Zanda, La Class Action pubblica tra interessi legittimi e giustiziabilità dell'azione amministrativa, en Urb. app., 2011, pp. 830 ss.; A. Massera, I criteri di economicità, efficacia ed efficienza, en M.A. Sandulli (encargado), Codice dell'azione amministrativa, cit., pp. 22 ss.; C. Marzuoli, II principio di buon andamento e il divieto di aggravamento del procedimento, allí pp. 206 ss.; M.R. Spasiano, II principio di buon andamento: dal metagiuridico alla logica del risultato in senso giuridico (Informe anual - 2011 - Italia), en http://www.ius-publicum.com. 
Sin embargo, con respecto a dichos nexos parece predominante el anclaje genético al principio de imparcialidad. Nótese que no parece que ni las más recientes indicaciones procedentes de la jurisprudencia del Tribunal Constitucional desmientan esta conclusión ${ }^{94}$.

Sobre el principio de justiciabilidad véase F. Saitta, Il principio di giustiziabilità dell'azione amministrativa, en http://www.giustizia-amministrativa.it, 2011.

Sobre el principio de responsabilidad véase L. R. Perfetti, Amministrazione pubblica e diritto amministrativo, cit., p. 18; D. Sorace, Diritto, cit., p. 69; E. Casetta, Manuale, cit., pp. 41 ss.

94 Entre las sentencias más recientes se puede hacer referencia, en primer lugar, a la n. ${ }^{\circ} 310$ del 5 de noviembre de 2010.

Con tal sentencia, el Consejo ha declarado la inconstitucionalidad de una ley (de la Región Liguria) que, para toda una categoría de procedimientos administrativos, había prescrito excluir la obligación de motivación. El Tribunal (en los puntos 6.1. y 6.2. en derecho) ha afirmado que "la obligación de motivar los procedimientos administrativos está destinada a realizar la posibilidad de tener conocimiento, y por lo tanto la trasparencia, de la acción administrativa. Esto enraíza en los arts. 97 y 113 Const., en tanto que, por un lado, constituye el corolario de los principios de buen desarrollo y de imparcialidad de la administración y, por otro lado, permite al destinatario de la disposición, que considere lesionada una situación jurídica propia, hacer valer la correspondiente tutela jurisdiccional ... En este marco, la disposición censurada no es conforme con los parámetros constitucionales arriba indicados ... Por lo tanto, se eluden los principios de publicidad y de trasparencia de la acción administrativa, aunque estén afirmados en el art. 1, párrafo 1, de la ley n. ${ }^{\circ} 241$ del 1990, a los cuales se reconoce el valor de principios generales destinados a aplicar tanto los cánones constitucionales de imparcialidad y buen desarrollo de la administración (art. 97, primer párrafo, Const.), como la tutela de otros intereses constitucionalmente protegidos, como es el derecho de defensa frente a la propia administración (arts. 24 y 113 Const.; sobre el principio de publicidad, sentencia n. ${ }^{\circ} 104$ del 2006, punto 3.2 de las Consideraciones en derecho). Y también queda verificada la exigencia de posibilidad de conocer la actuación administrativa, siendo también intrínsecos de ella los principios de buen desarrollo y de imparcialidad, exigencia que se realiza precisamente por medio de la motivación como instrumento destinado a externalizar las razones y el procedimiento lógico seguidos por la autoridad administrativa".

En esta sentencia, la remisión al principio de imparcialidad, aunque es intensa, parece situada en el mismo plano que la remisión a los principios de buen desarrollo y de justiciabilidad.

Mayor es, sin embargo, el peso asignado al principio de imparcialidad con respecto a todos los demás por la sentencia n. ${ }^{\circ} 175$ dell'’ de junio de 2011, relativa a la orientación jurisprudencial sobre cuya base los juicios de no admisión de los candidatos que participan en los exámenes de habilitación para el ejercicio de la profesión de abogado pueden estar motivados con la atribución de una mera puntuación numérica.

Allí (en el punto 3.1. en derecho), el Tribunal ha afirmado que "la motivación tiene la finalidad de hacer trasparente y controlable el ejercicio de la discrecionalidad administrativa, garantizando así la imparcialidad en la administración pública, así como la igualdad de trato de los ciudadanos ante ella", considerando que "sin embargo, no es exacto que el criterio de la puntuación numérica sea idónea para constituir la motivación del juicio valorativo expresado por la comisión examinadora”.

En este punto hay que subrayar uno de los principales argumentos utilizado por el Tribunal para sostener que la motivación en forma numérica no violaría el principio constitucional de imparcialidad.

El Tribunal pone de manifiesto que "no es sostenible que la puntuación indique solo el resultado de la valoración. En realidad, dicha puntuación se traduce en un juicio conjunto del rendimiento, a la luz de los parámetros dictados por el art. 22, párrafo noveno, del citado R.D.L. n. 1578 de 1933 ", ya que "la puntuación expresada debe encontrar parámetros específicos de referencia en los criterios de valoración contemplados en el art. 22, párrafo noveno, del real decreto-ley n. ${ }^{\circ} 1578$ del 27 de noviembre de 1933".

El citado art. 22, párrafo 9, del R.D.L. 1578/1933 establece la obligación para la comisión examinadora de predeterminar los criterios de valoración a los cuales deberá atenerse (en todo caso teniendo en cuenta los indicados directamente por el mismo art. 22, párrafo 9, en las letras a] hasta e]). Se trata de la figura que se examinará más abajo, en el apartado de conclusión 4, llamado comúnmente "autolímite" de la administración pública, el cual, como se verá, es expresión par excellence del principio de imparcialidad según el art. 97 Const.

El marco que de ello se deriva parece ser el siguiente. Para el Tribunal, la motivación se puede "atenuar" con respecto a la forma 'normal' (dicho en otros términos, se puede recurrir a la puntuación numérica en lugar 


\section{4. (sigue) Trasparencia y publicidad}

En relación con los principios de trasparencia y publicidad citados expresamente en el art. 1 de la L. 241/1990, una parte significativa de la doctrina los remite a aspectos, consecuencias o proyecciones del principio de imparcialidad95.

Sin embargo, otra parte de la doctrina vincula trasparencia y publicidad también a los principios de buena evolución, control democrático, justiciabilidad, igualdad, responsabilidad, al derecho a la información ${ }^{96}$; o, en otra perspectiva, a los principios de tutela de la legítima confianza97 o de tutela de la competencia ${ }^{98}$.

de al juicio discursivo) a condición, sin embargo, de que el principio de imparcialidad quede garantizado por la predeterminación puntual y analítica de los criterios de valoración por parte de la administración pública.

Esto confirma el supuesto que se defiende en el texto. La motivación, como la predeterminación de los criterios, es interna del sistema de la imparcialidad: tan cierto es esto que, si otros componentes del sistema (en el presente caso, el autolímite administrativo) están activos en medida suficiente para salvaguardar el valor de la imparcialidad, también será posible reducir la intensidad de un componente (en el presente caso, la forma de la motivación) sin comprometer el sistema.

95 P. Barile, I/ dovere di imparzialità della pubblica amministrazione, cit.; U. Allegretti, L'imparzialità, cit., pp. 240 ss.; Id., capítulo Imparzialità e buon andamento della pubblica amministrazione, cit., p. 138; G. Quadri, Riservatezza e trasparenza nell'esperienza costituzionale, en Aa.Vv., L'amministrazione pubblica tra riservatezza e trasparenza (Actas del XXXV Convegno di Studi di Scienza dell'Amministrazione, Varenna-ViIla Monastero, 21-23 de septiembre de 1989), Milán, Giuffré, 1991, pp. 47-48; G. Palma, Itinerari, cit., p. 294; F. Benvenuti, Disegno, cit., p. 239; L.R. Perfetti, Amministrazione pubblica e diritto amministrativo, cit., pp. 15-16; R. Caranta, Art. 97, cit., p. 1898; C. Taglienti, Trasparenza dell'atto amministrativo, en http://www. giustizia-amministrativa.it, 2007; R. Rolli, I principi dell'azione amministrativa, en F. Luciani - R. Rolli (encargado) Azione amministrativa e disciplina di diritto pubblico, Nápoles, ESI, 2008, p. 30; D. Sorace, Diritto, cit., p. 70; E. Casetta, Manuale, cit., p. 53.

96 Para la remisión de la trasparencia y de la publicidad a uno o más de los diversos principios aludidos en el texto, véase, con varios acentos, R. Villata, La trasparenza dell'azione amministrativa, en Dir. proc. amm., 1987, pp. 528 ss.; R. Marrama, La pubblica amministrazione tra trasparenza e riservatezza nell'organizzazione e nel procedimento amministrativo, en Dir. proc. amm., 1989, pp. 416 ss.; G. Arena, capítulo Trasparenza amministrativa, en Enc. giur., Roma, Treccani, 1995, pp. 1 ss.; Id., capítulo Trasparenza amministrativa, en S. Cassese (director), Dizionario di diritto pubblico, cit., vol. VI, pp. 5945 ss.; Id., Le diverse finalità della trasparenza amministrativa, en F. Merloni (encargado), La trasparenza amministrativa, Milán, Giuffré, 2008, pp. 29 ss.; M.R. Spasiano, Trasparenza e qualità dell'azione amministrativa, en Nuove autonomie, 2005, pp. 945 ss.; G. Morbidelli, II procedimento amministrativo, cit., p. 570; E. Carloni, Nuove prospettive della trasparenza amministrativa: dall'accesso ai documenti alla disponibilità delle informazioni, en Dir. pubbl., 2005, pp. 573 s.; Id., Gli strumenti della trasparenza nel sistema amministrativo italiano e la sua effettività: forme di conoscibilità, quantità e qualità delle informazioni, en F. Merloni (encargado), La trasparenza amministrativa, cit., pp. 349 ss.; Id., La 'casa di vetro' e le riforme. Modelli e paradossi della trasparenza amministrativa, en Dir. pubbl., 2009, pp. 779 ss.; P. Tanda, capítulo Trasparenza (principio di), en Dig. disc. pubbl., Aggiornamento, Turín, Utet, 2008, pp. 884 ss.; las contribuciones de F. Merloni, Trasparenza delle istituzioni e principio democratico, C. Marzuoli, La trasparenza come diritto civico alla pubblicità, D. Donati, Il principio di trasparenza in Costituzione, C. Cudia, Trasparenza amministrativa e pretesa del cittadino all'informazione: istituti/categorie di diritto pubblico e di diritto privato a confronto y A. Pioggia, La trasparenza dell'organizzazione e della gestione delle risorse umane nelle pubbliche amministrazioni, todos en F. Merloni (encargado), La trasparenza amministrativa, cit., respectivamente en las pp. 3 ss., 45 ss., 83 ss., 349 ss., 647 ss. y 693 ss.

97 Véase, por ejemplo, A. Police, Trasparenza e formazione graduale delle decisioni amministrative, en Dir. amm., 1996, pp. 229 ss., en particular pp. 262-264 e pp. 287 ss.; F. Manganaro, L'evoluzione del principio di trasparenza amministrativa, en http://www.astrid-online.it, 2009, en particular pp. 5-6.

98 Sobre todo con respecto a los principios de trasparencia y de publicidad en el tema de los concursos públicos: véase S.S. Scoca, I principi dell'evidenza pubblica, en C. Franchini (encargado), I contratti di 
En realidad, sin negar dichas conexiones, parece que se puede reiterar lo que se acaba de afirmar con respecto a la obligación de motivación (ésta también relacionada a menudo con el principio de trasparencia99): el fundamento constitucional primario de los principios de trasparencia y publicidad se debe encontrar en el art. $97 \mathrm{y}$, en especial, en el principio de imparcialidad allí consagrado.

Es así dado que, al igual que la motivación, la trasparencia y la publicidad son garantías indispensables de la posibilidad y de la efectividad de la participación procedimental y, por tanto, de la imparcialidad en su dimensión positiva: Io son ex ante, al igual que la motivación lo es ex post.

El secreto de los procedimientos y medidas, los obstáculos interpuestos a la accesibilidad de los actos, documentos e informaciones administrativas, las barreras ante la posibilidad de conocimiento, la difusión o comprensibilidad de estas últimas y la conclusión de la instrucción ante la intervención de los ciudadanos representarían factores de desintegración radical del principio participativo: si no puede existir participación sin trasparencia y publicidad, recíprocamente la imparcialidad exige e implica dichos principios ${ }^{100} \mathrm{y}$, por tanto, los fundamenta, en el an, con respecto al peculiar campo de la acción administrativa, según una relación de correspondencia proporcional entre calidad y cantidad de la trasparencia y de la publicidad, y calidad y cantidad de la imparcialidad entendida como apertura de la administración a la participación ${ }^{101}$.

appalto pubblico, en Trattato dei contratti dirigido por P. Rescigno y E. Gabrielli, Turín, Utet, 2010, en particular pp. 322 ss.; F. Manganaro, L'evoluzione del principio di trasparenza amministrativa, cit., p. 2 e pp. 8-11; A. Gandino, Sulla pubblicità delle sedute di gara: riflessioni a margine della trasparenza amministrativa nel codice dei contratti pubblici (e non solo), en Foro amm. - TAR, 2009, pp. 1276 ss.; I. Franco, Trasparenza e pubblicità nelle gare di appalto con il criterio dell'offerta economicamente più vantaggiosa, en Urb. app., 2009, pp. 137 ss.; M. Lipari, I principi di trasparenza e pubblicità, en G.A. Benacchio - D. De Pretis (encargado), Appalti pubblici e servizi di interesse generale (Actas de los seminarios celebrados en la Facultad de Jurisprudencia de Trento, noviembre-diciembre 2004), Trento, Università degli Studi, 2005, pp. 276 ss.

99 Véase retro, la anterior nota 89.

100 Sobre este punto, M.R. Spasiano, I principi di pubblicità, trasparenza e imparzialità, cit., observa (en la p. 90) que “la jurisprudencia administrativa, por lo demás, siempre ha sido proclive a reconocer una relación de funcionalidad necesaria entre la trasparencia y la imparcialidad de la acción administrativa, viendo en el primer principio la condición indispensable para el cumplimiento del segundo".

101 Por eso no resultan compartibles las posiciones que, postulando un 'desenganche' entre imparcialidad-participación y trasparencia, llega a afirmar que "la trasparencia se debe entender como principio general destinado a garantizar la posibilidad de conocer por la posibilidad de conocer, que precede y prescinde completamente de la información prescrita por la participación política, administrativa”: así C. Cudia, Trasparenza amministrativa e pretesa del cittadino all'informazione: istituti/categorie di diritto pubblico e di diritto privato a confronto, cit., p. 670 . Si se interrumpiese el vínculo entre trasparencia y participación, considerando que la primera debe actuar también cuando no haya ninguna razón para tutelar la segunda, se terminaría por legitimar una trasparencia autorreferencial y absolutizada, que correría el riesgo de desorbitar cualquier barrera de proporcionalidad distinta de los meros límites económicos y financieros, hasta hacer temer escenarios (casi 'orwellianos') de un exceso de exposición a la mera curiosidad de cualquier momento administrativo. Se derivarían graves riesgos: el de un "efecto distorsionador en procesos decisorios", destacado por F. Merloni, Trasparenza delle istituzioni e principio democratico, cit., p. 14 ("sometido a una trasparencia excesiva, el que toma las decisiones, político o administrativo, no adopta la 'justa decisión', la del interés general, sino la más próxima a las expectativas del público, o sea la más ‘conformista”’);
el de los retrasos o parálisis derivados de los temores de una burocracia excesivamente expuesta; el de una 
Con respecto a las relaciones entre trasparencia y publicidad, los dos conceptos no parecen coincidentes (a pesar de que en algunas reconstrucciones se tienda a configurarlos como un unicum ${ }^{102}$ ).

Las diferencias entre publicidad y trasparencia se han captado e interpretado de diferente forma ${ }^{103}$.

Parece convincente la tesis según la cual la trasparencia es un principio más amplio que exige el "conocimiento, efectivo (publicidad) o potencial (acceso), de las informaciones en manos de una institución (pública o privada)", conocimiento que a su vez debe ser "completo (en relación con el objeto), pleno (en relación con la comprensión) y difundido (en relación con los destinatarios)"; todo ello teniendo en cuenta el hecho de que, por un lado, "la integridad no está necesariamente en contradicción con la salvaguarda de otras exigencias, que pueden reducir el área del conocimiento de las informaciones sin por ello perjudicar la trasparencia", con especial atención a la "privacidad privada" y a la "privacidad pública"; por otro lado, que la trasparencia supone la garantía de la "seguridad (no modificabilidad, duración de la validez de los documentos)", de la "fiabilidad (sobre la procedencia del documento, sobre la veracidad de las informaciones contenidas en el mismo)" y, sobre todo, de la "comprensibilidad (de las actas, documentos e informaciones)" 104 para los ciudadanos.

Al asumir esta concepción del principio de trasparencia, el principio de publicidad no solo se pone en relación de species a genus con respecto al principio de trasparencia ${ }^{105}$, sino que, sobre todo, se configura como uno de los instrumentos de la trasparencia (entendida como resultado), en función subordinada con respecto a ésta, instrumento necesario, pero no suficiente de por sí para asegurar la efectividad del principio de trasparencia ${ }^{106}$.

atención excesiva, por parte de los órganos de orientación política y administrativa, a la apariencia más que al ser de la actuación pública. Paradójicamente, de este modo el exceso de trasparencia podría además perjudicar al principio de imparcialidad en lugar de garantizarlo: esto no se puede aceptar. La trasparencia, en definitiva, debe encontrar su recinto -insalvable- en la imparcialidad administrativa porque no puede entrar en conflicto con esta última. Lo cual confirma que es la imparcialidad la que debe representar el principal fundamento de la trasparencia administrativa, su fuerza motriz y, a la vez, a su necesaria vía.

102 Véase, por ejemplo, el planteamiento de V. Cerulli Irelli, Lineamenti, cit., p. 255.

103 Sobre los diversos modos de entender la diferencia entre trasparencia y publicidad véase por ejemplo, entre las contribuciones citadas en las anteriores notas 95, 96 y 98, las de R. Marrama, G. Arena, P. Tanda, F. Merloni, C. Marzuoli, F. Manganaro, E. Casetta, y aquí también M.R. Spasiano, I principi di pubblicità, trasparenza e imparzialità, cit., pp. 89-95.

104 F. Merloni, Trasparenza delle istituzioni e principio democratico, cit. (las citas están sacadas de las pp. 11, 14-15 e 17).

105 M.R. Spasiano, I principi di pubblicità, trasparenza e imparzialità, cit., p. 94.

106 Sobre la publicidad como un instrumento (aunque no el único) de la trasparencia, véase los recientes trabajos de F. Merloni, Trasparenza delle istituzioni e principio democratico, cit., pp. 8 ss.; E. Carloni, Gli strumenti della trasparenza nel sistema amministrativo italiano, cit., pp. 371 ss.; P. Tanda, capítulo Trasparenza (principio di), cit., p. 894; F. Manganaro, L'evoluzione del principio di trasparenza amministrativa, cit., p. 2; D. Sorace, Diritto, cit., p. 354. 
De hecho, el principio de publicidad consiste en la obligación para la administración pública de dar a conocer a todos, por iniciativa propia, determinadas categorías de informaciones y hacer que todos las utilicen (integradas en actas, documentos o soportes materiales o informáticos de cualquier naturaleza) por ésta conservadas, es decir, de ponerlas a disposición del público en vez de mantenerlas secretas, reservadas o en todo caso a disposición restringida solo de algunos sujetos, públicos o privados $^{107}$.

El principio de publicidad, en dicha perspectiva, exige medidas positivas para lograr el conocimiento a cargo de las administraciones, con las que estas últimas permitan a los ciudadanos, tanto con instrumentos tradicionales (publicación en los periódicos o boletines oficiales, fijación en tablones públicos de anuncios), como a través de las más modernas tecnologías digitales (publicación en sitios internet, en redes telemáticas, en bases de datos públicas que se puedan consultar libremente on line, etc.), recibir informaciones sin que ellos estén obligados a presentar a la administración pública una petición formal de admisión o a cumplir con particulares obligaciones procedimentales ${ }^{108}$.

Bajo este perfil, el principio de publicidad se distingue de otro instrumento de protección de la trasparencia, concretamente el derecho de acceso ${ }^{109} \mathrm{a}$

107 En este sentido véase F. Merloni, Trasparenza delle istituzioni e principio democratico, cit., pp. 7-9.

108 Sobre el principio de publicidad y sobre las normas que constituyen su aplicación, además de los Autores citados en la anterior nota 98, véase (también en cuanto a las oportunas referencias bibliográficas) A. Meloncelli, capítulo Pubblicità (diritto pubblico), en Enc. dir., Milán, Giuffré, 1988, pp. 1027 ss.; D. Corletto, capítulo Pubblicità degli atti amministrativi, en Enc. giur., Roma, Treccani, 1991; A.G. Orofino, La pubblicità telematica nell'impianto del Codice dell'amministrazione digitale, en Inf. dir., 2005, pp. 147 Ss.; B.G. Mattarella, Il rilievo costituzionale del principio di pubblicità, en Giorn. dir. amm., 2007, pp. 169 ss.; P. Gotti, Principio di pubblicità dell'azione amministrativa e tutela del diritto di opzione del candidato eletto in più circoscrizioni alle elezioni europee, en Giur. it., 2007, pp. 574 ss.; E. Carloni, Gli strumenti della trasparenza nel sistema amministrativo italiano, cit., en particular pp. 372-373; Id., L'obbligo di pubblicazione, en M.A. SanduIli (encargado), Codice dell'azione amministrativa, cit., pp. 1192 ss.; M.R. Spasiano, I principi di pubblicità, trasparenza e imparzialità, cit., pp. 94-95.

109 De todos modos, algunos Autores siguen siendo contrarios a configurar el derecho de acceso como instrumento de la trasparencia, en términos absolutos o relativos. Véase, por ejemplo, N. Paolantonio, L'accesso alla documentazione amministrativa, en F.G. Scoca (encargado), Diritto amministrativo, cit., p. 244: el autor, partiendo del art. 24, párrafo 3, de la L. 241/1990, según el cual "no son admisibles instancias de acceso destinadas a un control generalizado de la actuación de las administraciones públicas", afirma que "la figura del acceso, por tanto, no es expresión del principio de trasparencia". Véase también C. Cudia, Trasparenza amministrativa e diritti di informazione del cittadino nei riguardi delle amministrazioni regionali, en F. Merloni (encargado), La trasparenza amministrativa, cit., pp. 131 ss.: la Autora, por un lado, combina trasparencia y publicidad en un unitario "principio de trasparencia-publicidad", entendiéndolo como "exposición al público (a cualquiera) de la información administrativa ... condición permanente de posibilidad de conocimiento que se impone constitucionalmente como regla de la organización y de la actividad administrativa" (p. 132 y allí nota 84); por otro lado, considera que "el derecho de acceso ... no es por tanto un instrumento de trasparencia (porque el problema del acceso se plantea precisamente allí donde una información dada no está ya disponible para cualquiera), sino que -por el contrario- es un remedio a una situación de falta de publicidad” (p. 151). F. Merloni, Trasparenza delle istituzioni e principio democratico, cit., p. 9, distingue entre "el acceso subjetivamente delimitado ... el de ... nuestra L. n. ${ }^{\circ} 241$ " y "el acce346 nes)", concluyendo en el sentido de que "el acceso subjetivamente delimitado ... es un instrumento de 


\author{
las actas y a los documentos administrativos (artículos 22 y siguientes de la \\ Ley $\left.241 / 1990^{110}\right)$.
}

\begin{abstract}
conocimiento que, sin embargo, no asegura el conocimiento difuso que constituye trasparencia”, mientras que "solo el acceso potencialmente general, como instrumento del derecho a saber que tiene el ciudadano, es instrumento de trasparencia”. Distinta es la opinión de C. Marzuoli, La trasparenza come diritto civico alla pubblicità, cit., pp. 49 ss. El Autor observa que "la normalización junta trasparencia y acceso, a partir del art. 22 L. n. ${ }^{\circ}$ 241/1990. Y es natural. A través del otorgamiento del poder de conocer dado a alquien se realiza una medida de trasparencia". De todos modos -indica Marzuoli- "hay trasparencia y trasparencia; es necesario aislar y no superponer fenómenos y significados que son estructuralmente muy distintos. Por tanto: la trasparencia, que con la L. 15/2005 entra a formar parte de forma expresa de los principios enunciados en el art. 1 L. n. ${ }^{\circ}$ 241/1990... puede remitir: a la posibilidad de conocimiento de ciertas entidades operadas por sujetos portadores de ciertos intereses, o a la condición objetiva de posibilidad de conocimiento. En este segundo caso, trasparencia equivale a publicidad en sentido pleno, absoluto".
\end{abstract}

Hay que destacar que, de todos modos, la mayor parte de la doctrina sigue siendo favorable a configurar el derecho de acceso del que tratan los arts. 22 y ss. de la L. 241/1990 como instrumento del principio de trasparencia administrativa (si bien como instrumento no suficiente, por sí solo, para garantizar plenamente la trasparencia como resultado): en este sentido véase, por ejemplo, R. Villata, La trasparenza, cit., p. 529; F. Patroni Griffi, Un contributo alla trasparenza dell'azione amministrativa: partecipazione procedimentale e accesso agli atti, en Dir. proc. amm., 1992, pp. 56 ss.; R. Chieppa, La trasparenza come regola della pubblica amministrazione, en Dir. econ., 1994, p. 621; G. Arena, capítulo Trasparenza amministrativa, en Enc. giur., cit., p. 2; Id., capítulo Trasparenza amministrativa, en S. Cassese (diretto da), Dizionario di diritto pubblico, cit., p. 5950; G. Clemente di San Luca, Diritto di accesso e interesse pubblico, Nápoles, Jovene, 2006, en particular pp. 16 ss., 89 ss. e 121 ss.; G. Corso, Manuale di diritto amministrativo, Turín, Giappichelli, 2008, p. 257; E. Carloni, Gli strumenti della trasparenza nel sistema amministrativo italiano, cit., pp. 352 ss.; F. Manganaro, L'evoluzione del principio di trasparenza amministrativa, cit., pp. 3-4; A. Crosetti - A. Giuffrida, Lineamenti, cit., p. 147; D. Sorace, Diritto, cit., pp. 353-354; E. Casetta, Manuale, cit., p. 53; R. Chieppa - R. Giovagnoli, Manuale, cit., p. 547; A. Simonati, I principi in materia di accesso, en M.A. Sandulli (encargado), Codice dell'azione amministrativa, cit., pp. 1032 ss.

110 La relación de instrumentalidad entre el derecho de acceso y los principios de trasparencia y de imparcialidad está sancionado positivamente por la propia formulación del art. 22, párrafo 2, de la L. 241/1990, en el texto sustituido por el art. 10, párrafo 1, de la L. 69/2009: allí, en términos que no dejan espacio a equívocos, se establece que "el acceso a los documentos administrativos, dadas sus relevantes finalidades de interés público, constituye un principio general de la actividad administrativa con objeto de favorecer la participación y asegurar la imparcialidad y la trasparencia". Además, el art. 27 de la misma L. 241/1990 (en el texto enmendado por el art. 18 de la L. 15/2005), al instituir la autoridad administrativa independiente denominada "Comisión para el acceso a los documentos administrativos", establece que esta última "vigila para que se aplique el principio de plena posibilidad de conocimiento de la actividad de la administración pública respetando los límites fijados por la presente ley" y "redacta un informe anual sobre trasparencia de la actividad de la administración pública, que comunica a las Cámaras y al Presidente del Consejo de ministros". Sobre el derecho de acceso que tratan los arts. 22 y ss. de la L. 241/1990, en la inmensa bibliografía véase G. Arena (encargado), L'accesso ai documenti amministrativi, Bolonia, Il Mulino, 1991; A. Romano Tassone, Considerazioni in tema di diritto di accesso, en Aa.vv., Scritti per Enzo Silvestri, Milán, Giuffré, 1992, pp. 431 ss.; Id., A chi serve il diritto di accesso? (Riflessioni su legittimazione e modalità d'esercizio del diritto di accesso nella I. n. ${ }^{\circ}$ 241/1990), en Dir. amm., 1995, pp. 315 ss.; C. Marzuoli, Diritto d'accesso e segreto di ufficio, en M. Cammelli - M. P. Guerra (encargado), Informazione e funzione amministrativa, Rimini, Maggioli, 1997, pp. 257 ss.; L.A. Mazzarolli, L'accesso ai documenti della pubblica amministrazione. Profili sostanziali, Padua, Cedam, 1998; C.E. Gallo - S. Foà, capítulo Accesso agli atti amministrativi, en Dig. disc. pubbl., Aggiornamento,Turín, Utet, 2000, pp. 1 ss.; M.A. Sandulli, capítulo Accesso alle notizie e ai documenti amministrativi, en Enc. dir., Aggiornamento, Milán, Giuffré, 2000, pp. 1 ss.; A. Simonati, L'accesso amministrativo e la tutela della riservatezza, Trento, Università degli studi, 2002; C. Mucio, Codice della privacy e pubblica amministrazione: diritto di accesso e riservatezza nella administración pública e negli enti locali, Milanofiori-Assago, Ipsoa, 2005; F. Pubusa, Diritto di accesso ed automazione: profili giuridici e prospettive, Turín, Giappichelli, 2006; G. Clemente di San Luca, Diritto di accesso e interesse pubblico, cit.. Véanse las recientes contribuciones de A. Simonati, I principi in materia di accesso e L'ambito di applicazione del diritto 
De hecho, la publicidad tiene un contenido predeterminado (la administración pública publica solo algunas categorías predefinidas de informaciones) y ve a la administración pública en posición activa y a los ciudadanos en posición pasiva; en cambio, el acceso tiene un contenido no predeterminado (el ciudadano es quien elige e indica cuáles son las actas, documentos o informaciones que pretende obtener y conocer) y ve al ciudadano en posición activa y a la administración pública en posición pasiva (el ciudadano es quien, activando un procedimiento particular, debe presentar instancia para que se le permita el conocimiento de actas, documentos o informaciones que la administración pública no haya publicado por iniciativa propia). Por lo tanto, publicidad y acceso son complementarios; donde actúe la primera, el segundo es superfluo para el ciudadano; donde actúe el segundo, el ciudadano completa su patrimonio de informaciones obteniendo algunas que la administración pública no "expuso" a través de la publicidad"11.

En relación con el principio-genus de trasparencia, son múltiples los conjuntos de normas que, según la doctrina, constituyen su aplicación concreta. Entre ellos, por ejemplo, además del derecho de acceso, las normas de la participación procedimental y la obligación de motivación, se pueden citar: el responsable del procedimiento administrativo (figura esencial como punto de interlocución constante entre la administración pública y los ciudadanos involucrados por un procedimiento dado, regulada por los artículos 5 y 6 de la L. 241/1990); las U.R.P. (oficinas para las relaciones con el público, previstas en línea general por el art. 11 del D.Igs. 165/2001, con la tarea de suministrar, incluso mediante la utilización de tecnologías informáticas, al servicio a los usuarios para los derechos de participación según el capítulo III de la L. 241/1990, la información para los usuarios correspondiente a las actas y al estado de los procedimientos y a la investigación y análisis destinados a la formulación de propuestas a la propia administración sobre los aspectos organizativos y logísticos de la relación con los usuarios); los modelos y sistemas informativos útiles para la interconexión entre administraciones públicas (véase el art. 10 del D.lgs., 165/2001); en general, los instrumentos y el conjunto de normas de la así llamada administración digital, entre los cuales está el PEC (correo electrónico certificado), regulados actualmente de manera orgánica por el Código de la administración digital en virtud del D.lgs. 82/2005; las actividades de información y comunicación institucional de las administraciones públicas, reguladas por la L. 150/2000, etc. ${ }^{112}$.

di accesso, S. Baccarini, Posizione giuridico-soggettiva dell'aspirante all'accesso amministrativo: natura giuridica e implicazioni applicative, A. Contieri - G. Di Fiore, L'accesso alle informazioni ambientali (D.lg. 19 de agosto de 2005 n. ${ }^{\circ}$ 195), F. Manganaro, L'accesso agli atti ed alle informazioni degli enti locali y P. Alberti, I casi di esclusione dal diritto d'accesso, en M.A. Sandulli (encargado), Codice dell'azione amministrativa, cit., alle pp. 1004-1122.

111 Véase también F. Merloni, Trasparenza delle istituzioni e principio democratico, cit., pp. 9-11.

112 Sobre esta reseña, no exhaustiva, de las normas que la doctrina mayoritaria reconduce al principio de trasparencia véase E. Carloni, Gli strumenti della trasparenza, cit., pp. 352 ss; P. Tanda, capítulo Trasparenza (principio di), cit., pp. 899 ss.; E. Casetta, Manuale, cit., pp. 53-54; D. Sorace, Diritto, cit., pp. 70 e 353 ss. Sobre las actividades de información y de comunicación desarrolladas por las administraciones 348 públicas véase, para una visión de conjunto, B.G. Mattarella, capítulo Informazione amministrativa, en S. Cassese (director), Dizionario di diritto pubblico, cit., vol. IV, pp. 3126 ss.; F. Manganaro - A. Romano Tassone 
En relación con el principio-species de publicidad, constituyen su aplicación, por ejemplo, la previsión según el art. 26 de la L. 241/1990 ${ }^{113}$ o, en el ámbito específico de los contratos públicos, la norma de la publicidad de las sesiones de la Comisión de adjudicación ${ }^{114}$.

La forma de concebir y tutelar los principios de trasparencia y publicidad ha experimentado recientemente una evolución importante con el paquete de medidas conocidas con el nombre de reforma "Brunetta" (que incluye, además de la L. 15/2009 y los Decretos Legislativos 150/2009 y 198/2009, también algunas disposiciones de la L. 133/2008 y de la L. 69/2009) ${ }^{115}$.

(encargado), I nuovi diritti di cittadinanza: il diritto d'informazione (Actas de la Convención de Copanello, 25-26 de junio de 2004), Turín, Giappichelli, 2005; G. Arena (encargado), La funzione di comunicazione nelle pubbliche amministrazioni, Santarcangelo di Romagna, Maggioli, 2004; F. Merloni (encargado), L'informazione delle pubbliche amministrazioni, Rimini, Maggioli, 2002.

113 El art. 26 de la L. 241/1990 establece:

“1. Quedando salvo lo previsto para las publicaciones en el Boletín Oficial de la República Italiana por la ley n. ${ }^{\circ} 839$ del 11 de diciembre de 1984 y por las correspondientes normas de actuación, se han publicado, según las modalidades previstas por los distintos ordenamientos, las directrices, los programas, las instrucciones, las circulares y todo acto que dispone en general sobre la organización, las funciones, los objetivos y los procedimientos de una administración pública en la cual se determina la interpretación de normas jurídicas o se dictan disposiciones para la aplicación de las mismas.

2. También se han publicado, en las formas antes mencionadas, los informes anuales de la Comisión que trata el artículo 27 y, en general, se ha dado la máxima publicidad a todas las disposiciones de aplicación de la presente ley y a todas las iniciativas destinadas a precisar y a hacer efectivo el derecho de acceso.

3. Con la publicación a la que se refiere el párrafo 1, allí donde sea integral, la libertad de acceso a los documentos indicados en dicho párrafo 1 se entiende realizada".

Sobre la disposición véase el comentario de E. Carloni, L'obbligo di pubblicazione, cit.

114 Sobre la cual véase en particular P. Cortese, I/ principio di pubblicità delle sedute di gara e I'invalidità degli atti della relativa procedura selettiva, en Riv. trim. app., 2008, pp. 636 ss.; A. Gandino, Sulla pubblicità delle sedute di gara, cit.; M.R. Spasiano, I principi di pubblicità, trasparenza e imparzialità, cit., pp. 94-95. A este respecto se señala la sentencia de la Sesión Plenaria del Consejo de Estado n. ${ }^{\circ} 13$ del 28 de julio de 2011, según la cual en las licitaciones con el criterio de la oferta económicamente más ventajosa la apertura por parte de la Comisión de las plicas que contengan la oferta técnica se debe realizar, necesariamente, en sesión pública (mientras que en sesión a puerta cerrada la Comisión procede tan solo a la valoración de las ofertas técnicas para la atribución de las puntuaciones). La Sesión Plenaria ha establecido que “el principio de publicidad de los concursos para las contratas públicas tiene sus raíces en cánones del derecho comunitario e interno constantemente aplicados por la jurisprudencia administrativa. A este respecto resulta fácil la referencia, además de al art. 97 de la Constitución, a las Directivas 2004/17/CE y 2004/18/ CE, de las cuales ha dimanado el Código italiano de los contratos públicos, las cuales, en los artículos 10 y 2 respectivamente, establecen con expresión de alcance ineludible que: "Las administraciones adjudicatarias ... actúan con trasparencia”. "La publicidad de las sesiones es la principal manifestación de la trasparencia administrativa ..." -afirma una decisión de la Sección remitente (16 de junio de 2005, n. ${ }^{\circ} 3166$ ), luego confirmada por el D.Lgs. n. ${ }^{\circ} 163$ de 2006, que, al trasponer las directivas mencionadas, en el art. 2, párrafo 1, especifica el precepto comunitario imponiendo que la adjudicación de las contratas públicas se realice respetando el principio, además del de trasparencia, de "publicidad con las modalidades indicadas por el presente código". Y si bien es verdad que el D.Lgs. n. ${ }^{\circ} 163$ no enuncia directamente ninguna regla específica en materia de desarrollo de las sesiones del concurso... en el párrafo 3 del mismo art. 2 hace que sean aplicables las disposiciones sobre el procedimiento administrativo que trata la ley n. 241 del 1990 ”.

115 La L. 15/2009 lleva por título "Delegación al Gobierno destinada a optimizar la productividad del trabajo público y la eficiencia y trasparencia de las administraciones públicas, así como disposiciones complementarias de las funciones atribuidas al Consejo nacional de Economía y Trabajo y al Tribunal de Cuentas". 

reforma.

En este punto no es posible profundizar en los numerosos contenidos de la

Sin embargo, es preciso subrayar al menos tres puntos clave con respecto a la temática de la trasparencia.

En primer lugar, la institución de una autoridad administrativa independiente, denominada "Comisión para la valoración, trasparencia e integridad de las administraciones públicas" (CiVIT) ${ }^{116}$.

Ésta, además de dirigir, coordinar y supervisar el ejercicio independiente de las funciones de valoración de la performance organizativa e individual de las administraciones públicas, garantizar la trasparencia de los sistemas de valoración y asegurar la comparabilidad y visibilidad de los índices de desarrollo de la gestión, se ocupa de favorecer, "en la administración pública, la cultura de la trasparencia también a través de instrumentos de prevención y de lucha contra la corrupción”, por medio de una apropiada articulación interna denominada "Sección para la integridad en las administraciones públicas". Esta última, en especial, prepara las Directrices del "Programa trienal para la integridad y la trasparencia" que cada administración pública debe adoptar, comprueba su efectiva adopción y vigila el cumplimiento de las obligaciones en materia de trasparencia por parte de cada administración ${ }^{117}$.

En segundo lugar, la previsión de la obligación para cada administración pública, en cumplimiento de las Directrices establecidas por CiVIT, de aplicar el propio “Programa trienal para la integridad y trasparencia"118, es decir, un paquete coordinado de medidas e iniciativas a las que cada entidad pública se autovincula con los ciudadanos para elevar el propio grado de trasparencia; el Plan trienal se deberá elaborar tras haber escuchado a las asociaciones de ciudadanos, consumidores y usuarios repre-

\footnotetext{
El D.Lgs. 150/2009 lleva por título “Aplicación de la ley n. ${ }^{0} 15$ del 4 de marzo de 2009 en materia de optimización de la productividad del trabajo público y de eficiencia y trasparencia de las administraciones públicas".

El D.Lgs. 198/2009 lleva por título “Aplicación del artículo 4 de la ley n. ${ }^{1} 15$ del 4 de marzo de 2009 en materia de recurso para la eficiencia de las administraciones y de los concesionarios de servicios públicos".

Sobre la llamada Reforma 'Brunetta', véanse las referencias bibliográficas citadas en la anterior nota 93 y en las posteriores notas 116, 118 y 129, y véanse, para una visión de conjunto, las consideraciones de $\mathrm{E}$. Casetta, Manuale, cit., pp. 53 e 163 ss.

116 M. Clarich - B.G. Mattarella, La Commissione per la valutazione, la trasparenza e l'integrità delle amministrazioni pubbliche nel panorama delle autorità amministrative indipendenti, en G. Scognamiglio (encargado), II nuovo ordinamento del lavoro pubblico e il ciclo della performance: programmazione, valutazione e controllo dopo la riforma Brunetta (L. 15/2009 e D.Igs 150/2009), Soveria Mannelli, Rubbettino, Promo P.A. Fondazione, 2010, pp. 133-148; A. Martone, Il ruolo della Commissione per la valutazione, la trasparenza e I'integrità delle amministrazioni pubbliche, en Giur. it., 2010, pp. 2703 ss.; B. Ponti, I primi sei mesi di attività della CIVIT, en Giorn. dir. amm., 2010, pp. 986 ss.; E. D'Alterio, Il bilancio della CIVIT a un anno dalla sua istituzione, en Riv. trim. dir. pubbl., 2011, pp. 598 ss.

117 Art. 4, párrafo 2, letra f), de la L. 15/2009 y art. 13 del D.Lgs. 150/2009.

118 E. D’Alterio, Il programma triennale per la trasparenza e l'integrità (comentario sobre la Resolución de la Comisión independiente para la valoración, la trasparencia y la integridad de las administraciones públicas [CiVIT], nº 105 del 14 de octubre de 2010), en Giorn. dir. amm., 2011, pp. 440 ss.
} 
sentadas en el Consejo nacional de consumidores y usuarios y también deberá hacerse público a través de los sitios web de las administraciones públicas que lo apliquen ${ }^{119}$.

Finalmente, y sobre todo, la dilatación de la amplitud del concepto de "trasparencia".

En la reforma "Brunetta", la trasparencia se define enfáticamente como "accesibilidad total, también a través del instrumento de la publicación en los sitios institucionales de las administraciones públicas, de las informaciones concernientes a cualquier aspecto de la organización, de los indicadores relacionados con las evoluciones de la gestión y la utilización de los recursos para el seguimiento de las funciones institucionales, así como de los resultados de la actividad de medición y valoración desempeñada por los órganos competentes, con objeto de favorecer formas difundidas de control del cumplimiento de los principios de buen desarrollo e imparcialidad", capaz de constituir un "grado esencial de las prestaciones suministradas por las administraciones públicas según el artículo 117, párrafo segundo, letra m), de la Constitución”"120.

En esta concepción, la dimensión privilegiada (aunque no única ${ }^{121}$ ) de la trasparencia se convierte en la así llamada trasparencia ex ante, es decir, la publicidad on line $e^{122}$ en los sitios web institucionales de cada administración de enormes "bloques" de datos, noticias e informaciones no solo sobre las esferas impersonales de la actividad y la organización, sino también, por ejemplo, los curricula, las retribuciones, los cargos adicionales y los índices de presencia y ausencia de cada persona con cargo de directivo o empleado público (medidas análogas tienen que ver también con los órganos políticos) $)^{123}$.

119 Art. 4, párrafo 2, letra h), n. ${ }^{\circ} 3$ ) de la L. 15/2009; art. 11, párrafos 2, 7, 8 y 9, art. 13, párrafo 6, letra e) y párrafo 8 , art. 15, párrafo 2, letra d), del D.Lgs. 150/2009. Véase también la Resolución CiVIT n. ${ }^{\circ} 105$ del 14 de octubre de 2010 (en la dirección URL http://www.civit.it/wp-content/uploads/Delibera-n.105.20102. pdf), titulada "Líneas maestras para la preparación del Programa trienal sobre trasparencia e integridad".

120 Art. 11, párrafo 1, del D.Lgs. 150/2009; art. 4, párrafo 7, de la L. 15/2009.

121 Según la Resolución CiVIT n. ${ }^{10} 105$ del 14 de octubre de 2010 (par. 1.2.), "la aplicación de la disciplina de la trasparencia no se agota con la publicación on line de datos, sino que prevé instrumentos ulteriores. El artículo 11, párrafo 2, del d.Ig. n. ${ }^{\circ} 150$ de 2009, de hecho, hace referencia a "iniciativas" destinadas a garantizar un grado de trasparencia adecuado, así como a favorecer la legalidad y el desarrollo de la cultura de la integridad. Bajo esta perspectiva hay que interpretar las “jornadas específicas de la trasparencia” que menciona el párrafo 6 del artículo 11 y los requisitos de correo electrónico certificado que menciona el anterior párrafo 5. En conclusión, merece subrayarse que la aplicación de la disciplina de la trasparencia requiere el concurso de acciones positivas a cargo de las distintas administraciones, pero también de los sujetos encargados de la vigilancia ... consistentes en la observación inmediata de las obligaciones puntuales actualmente vigentes, en la adopción y la aplicación del Programa trienal de trasparencia e integridad, en el cual ... se deben incluir iniciativas ulteriores destinadas a promover la trasparencia y la cultura de la integridad".

122 Sobre este punto véase en particular la aportación de E. Carloni, La 'casa di vetro' e le riforme. Modelli e paradossi della trasparenza amministrativa, cit.

123 Hay que añadir que el art. 4, párrafo 9, de la L. 15/2009 ha modificado el art. 1, párrafo 1, del Código in materia de protección de los datos personales que trata el D.Lgs. 196/2003, estableciendo que "las noticias concernientes al desarrollo de las prestaciones de cualquiera que desempeñe una función pública, y la valoración correspondiente, no son objeto de de protección de la reserva personal”. Para entender cuál 
es la ingente cantidad de informaciones sujetas a publicidad necesaria, basta desplegar la lista de conjunto que presenta la Resolución CiVIT n. ${ }^{\circ} 105$ del 14 de octubre de 2010 (par. 4.2.), en donde se reordenan y se racionalizan todas las obligaciones vigentes de publicación on line por parte de las administraciones, las cuales afectan a: el Programa trienal para la trasparencia y la integridad, y el correspondiente estado de aplicación; el Plan y el Informe sobre la performance; las informaciones que conciernen a cada aspecto de la organización (organigrama, articulación de las oficinas, atribuciones y organización de cada oficina incluso a nivel directivo no general, nombres de los directivos responsables de las distintas oficinas, así como el sector del ordenamiento jurídico referido a las actividades que éstas desempeñan); la lista completa de los apartados de correo electrónico institucionales activos; la lista de las tipologías de procedimiento aplicadas por cada oficina de nivel directivo no general, el plazo para la conclusión de cada procedimiento y cualquier otro plazo procedimental, el nombre del responsable del procedimiento y la unidad de la organización responsable de la instrucción y de cualquier otro cumplimiento procedimental, así como la adopción de la disposición final; las informaciones sobre la cantidad de los servicios prestados; la Carta sobre la calidad de los servicios; los curricula y las retribuciones de los directivos (con indicación específica de los componentes variables de la retribución y de los componentes vinculados a la retribución por resultado), las direcciones correspondientes de correo electrónico, números de teléfono de uso profesional, cargo, fecha de adscripción al grado de pertenencia o al inferior, fecha de comienzo al servicio de la administración, inicio y finalización de los cargos otorgados en virtud del artículo 19, párrafos 3 y 4, del D.Lgs. 165/2001; los curricula de los titulares de cargos de organización; los curricula, las retribuciones, las compensaciones y las indemnizaciones de aquellos que ocupen cargos de orientación política o administrativa y de las correspondientes oficinas de apoyo, incluidos, a título de ejemplo, los altos cargos políticos de las administraciones, los jefes de gabinete y los miembros de las oficinas de staff y de colaboración directa en los ministerios; los titulares de otros cargos de relieve político en las regiones y en los entes locales; los titulares y los curricula de los componentes de los organismos independientes de valoración de la performance (OIV) y del responsable de las funciones de medición de la performance; los índices de ausencia y de mayor presencia del personal, diferenciados por oficinas de nivel directivo, así como el papel de los empleados públicos; las retribuciones anuales, los curricula, las direcciones de correo electrónico, los números de teléfono de uso profesional de secretarios provinciales y municipales; el importe conjunto de las primas específicas vinculadas a la performance y el importe de las primas efectivamente distribuidas; el análisis de los datos correspondientes al grado de diferenciación en la utilización del sistema de primas, ya sea para los directivos como para los empleados; los Códigos de comportamiento de los funcionarios públicos aplicados por cada administración pública; los datos correspondientes a tareas retribuidas y no retribuidas confiadas a empleados públicos y a otros sujetos (ya se hayan conferido o autorizado por una administración a los propios empleados en el seno de la propia administración o en otras administraciones o sociedades públicas o privadas; los conferidos o autorizados por una administración a los empleados de otra administración; los confiados, bajo cualquier título, por una administración a sujetos externos), con indicación del sujeto encargado, del curriculum de tal sujeto, del objeto del encargo, de la duración correspondiente, de la retribución bruta, del sujeto otorgante, de las modalidades de selección y de otorgamiento del encargo y del tipo de relación, con eventual declaración negativa en el caso de que la administración no haya conferido o autorizado encargos; la indicación de los servicios prestados a los usuarios finales e intermedios, la contabilización de los correspondientes costes y el reflejo de los costes efectivos y los imputados al personal por cada servicio prestado, así como el seguimiento de su desarrollo; los contratos complementarios estipulados, el informe técnicofinanciero y descriptivo, certificado por los órganos de control, las informaciones trasmitidas para su envío al Tribunal de Cuentas, el modelo adoptado y los resultados de la valoración realizada por los ciudadanos sobre los efectos esperados del funcionamiento de los servicios públicos como consecuencia de la negociación complementaria; los datos concernientes a consorcios, entidades y sociedades de las que formen parte las administraciones públicas, con la indicación, en el caso de sociedades, de la cuota de participación correspondiente; los datos relativos a la externalización de servicios y actividades incluso para el trámite de contratas; la indicación de los plazos medios de pago correspondientes a la adquisición de bienes, servicios y suministros (indicador de pagos en plazo), así como de los tiempos medios de definición de los procedimientos y de prestación de los servicios con referencia al ejercicio financiero precedente; los datos relativos a las buenas prácticas en cuanto a los tiempos para la adopción de las disposiciones y para la prestación de los servicios al público; el establecimiento, con acceso por vía informática, de registros de beneficiarios de disposiciones públicas de naturaleza económica; los datos previstos por el artículo 7 del D.Lgs. 163/2006 (Código de las contrataciones públicas de trabajos, servicios y suministros) ante el public procurement; la publicación de ulteriores datos que sirvan para garantizar un grado de trasparencia adecuado. 
De esta forma, la relación entre principio de trasparencia y principio de publicidad tiende a trasformarse desde el esquema de genus a species hasta el esquema de una superposición progresiva (aunque no total).

En conclusión, es importante observar cómo parece que el principio de trasparencia, según se entiende y deriva del conjunto de la reforma "Brunetta", sufra una especie de "torsión" legislativa.

De hecho, su centro de gravedad llega a estar representado, más que por el principio de imparcialidad, por el principio de buen desarrollo de la administración, que la reforma entiende en clave de optimización de la performance administrativa y, por tanto, de la eficiencia.

La performance se define, de hecho, como el nivel medible del alcance, por parte de cada estructura burocrática y de su personal, de los objetivos cuantitativos y cualitativos programados y fijados por los órganos de orientación política-administrativa, en relación con las necesidades de la colectividad, con la misión institucional y con las prioridades políticas y estratégicas, con atribución de los recursos correspondientes ${ }^{124}$.

En la inspiración de fondo de la reforma reciente, la trasparencia parece "servir" no tanto a la imparcialidad entendida en su dimensión positiva y "procedimental" de apertura a la participación, sino al buen desarrollo entendido como orientación al resultado en términos de "producto final", efectivo y tangible; la trasparencia se entiende en general como el encendido de potentes reflectores para detectar nichos de ineficiencia a través del incremento del control difuso de las "miradas" sobre la administración, para disuadir al personal administrativo de comportamientos laxistas o improductivos, dado que estos últimos, por el haz de luz lanzado sobre ellos, serían puestos al desnudo y estigmatizados de inmediato.

Esta forma de concebir el principio de trasparencia corre el riesgo de alejar el principio mismo de su anclaje prioritario en la imparcialidad, encadenándolo a la lógica (sin duda importante, pero de por sí parcial y limitada) del consumo informativo, en una especie de plaza-mercado perennemente abierta solo para los resultados o fracasos que la administración pública obtenga de modo que sean mensurables, cuantificables y que se puedan exponer al aprecio o desaprobación públicos.

Si dicha tendencia se radicalizara excesivamente, se podrían abrir escenarios poco deseables: los de una trasparencia vivida por los ciudadanos en una dimensión puramente virtual, "a distancia", como terminales pasivos de la recepción de una cascada de informaciones, en vez de una dimensión real, "cara a cara", como protagonistas activos de la utilización de dichas informaciones para su participación concreta en el ejercicio de la actividad administrativa, en cada episodio en el que esta última intercepta verdaderamente su vida, apelando no solo a la facultad de la "visión",

124 Véase la definición del ciclo de la performance que dimana de los arts. 3-10 del D.Lgs. 150/2009. 
sino también y sobre todo a la interlocución con la "voz" de las personas (la trasparencia para la participación).

\section{5. (sigue) Integridad}

La propia reforma "Brunetta", citada en el párrafo anterior, enlaza el principio de trasparencia con el de "integridad" de la administración y de sus órganos; la referencia a la "integridad" y a la "cultura de la integridad" está presente tanto en la misma denominación de CiVIT y de su correspondiente Sección para la integridad en las administraciones públicas, así como en el Programa trienal para la integridad y trasparencia, como en otras disposiciones de la L. 15/2009 y del D.Lgs. 150/2009 ${ }^{125}$.

Sin embargo, como ha observado la doctrina, si es verdad que el D.Lgs. 150/2009 introduce "por primera vez, además del principio de trasparencia, también el de integridad”, también es verdad que en el decreto legislativo falta (al contrario de lo que ocurre para la trasparencia) cualquier definición del principio de integridad, "cuyo contenido se deberá explicitar mejor también con el apoyo de la doctrina” ${ }^{26}$.

Sobre este punto puede resultar útil una referencia a la Decisión de CiVIT n. ${ }^{105}$ del 14 de octubre de 2010, en la que figuran las "Directrices para la preparación del Programa trienal sobre trasparencia e integridad" ${ }^{27}$, la cual parece vincular tendencialmente la integridad a dos polos.

Por un lado, la así llamada "ética pública” ( $\$ 1$ de la Decisión CiVIT) y, en especial, los "deberes de comportamiento de los titulares de funciones públicas" en cumplimiento de los “códigos de comportamiento" correspondientes (§ 1.1. de la Decisión) adoptados y hechos públicos por cada administración pública: se trata de la imparcialidad en su dimensión subjetiva, ya examinada retro en el anterior párrafo 3.1. ${ }^{128}$.

Por otro lado, el conjunto de medidas y de iniciativas, en el plano organizativo y funcional, capaz de tutelar la imparcialidad en su dimensión objetiva a través de la lucha contra un fenómeno patológico que constituye su negación radical: la corrupción administrativa. En este sentido, el principio de integridad se entrelaza con la "prevención de la corrupción en las administraciones públicas" (art. 1.1. de la misma Decisión (iVIT).

La integridad administrativa es síntesis de medidas de remedio, de antítesis, de contraste con la corrupción no en el plano punitivo (siendo dicha tarea competencia

125 Art. 11, párrafos 2, 7, 8 y 9, art. 12, párrafo 1, art. 13, art. 14, párrafo 4 y art. 15, párrafos 1 y 2, del D.Lgs. 150/2009.

126 Así F. Manganaro, L'evoluzione del principio di trasparenza amministrativa, cit., p. 12.

$354 \quad 127$ Véase la anterior nota 119. 
de las magistraturas, en especial la penal y la contable), sino en el plano preventivo, dado que debería actuar remontándose a los mecanismos que inducen o facilitan la permeabilidad de la administración pública a la corrupción ${ }^{129}$ : tema, por demás, sobre el que debe registrarse, en la disposición actual de las competencias institucionales, un estado de desorden organizativo que desde luego no es de ayuda para la eficacia de cualquier estrategia anticorrupción que pretenda imponerse a escala del sistema ${ }^{130}$.

129 El tema, amplísimo, es objeto de una amplia recopilación de contribuciones contenida en el volumen recopilatorio F. Merloni - L. Vandelli (encargado), La corruzione amministrativa: cause, prevenzione e rimedi, Firenze, Passigli, 2010. Sobre el tema véase también M.G. Vivarelli, Il fenomeno della corruzione, en Foro amm. - TAR, 2008, pp. 2928 ss.; Q. Lorelli, Controlli sulle pubbliche amministrazioni e prevenzione della corruzione, en Le Regioni, 2010, pp. 873 ss.; R. Nunin, Integrità e corruzione amministrativa. L'etica pubblica e il Codice di comportamento dei dipendenti delle amministrazioni pubbliche, en Riv. giur. lav. e prev. soc., 2010, pp. 523 ss.; R. Nobile, Trasparenza e integrità dell'azione amministrativa: un'analisi attraverso $i$ valori costituzionali di riferimento, en $R U$ - Risorse umane nella pubblica amministrazione, 2010, pp. 69 ss.; B.G. Mattarella, Un progetto della Scuola superiore della pubblica amministrazione sull'integrità nella pubblica amministrazione, en Riv. trim. dir. pubbl., 2011, pp. 597-598.

Consúltese, además, el Informe anual al Parlamento para el año 2010 del Servicio Anticorrupción y Trasparencia (S.A.eT.) del Departamento de la Función Pública - Presidencia del Consejo de Ministros, que se puede obtener en la dirección URL http://www.anticorruzione.it/Portals/altocommissario/Documents/A/tro/Anticorruzione.pdf(el Informe, entregado a los presidentes del Senado y de la Cámara de Diputados y publicado el 12 de mayo de 2011, pone a disposición la actualización del "Mapeado y los demás actos ilícitos contra la administración pública” en el sentido de los arts. 6 y 61 de la Convención ONU de Mérida contra la corrupción, ratificada en Italia con la L. n. ${ }^{\circ} 116$ del 3 de agosto de 2009).

130 Con el artículo 1 de la L. n. 3 del 16 de enero de 2003 se instituyó el Alto Comisario para la prevención y la detección de la corrupción y otras formas de actuación ilícita en el seno de la administración pública, regulado después por el D.P.R. n. ${ }^{\circ} 258$ del 6 de octubre de 2004. El Alto Comisario quedó después suprimido por el artículo 68, párrafo 6, del D.L. n. ${ }^{\circ} 112$ del 25 de junio de 2008 , traspuesto, con modificaciones, por la L. n. ${ }^{\circ} 133$ del 6 de agosto de 2008; el párrafo 6-bis del art. 68 del mismo D.L. n. ${ }^{\circ} 112 / 2008$, en el texto resultante de la ley de conversión n. ${ }^{\circ} 133 / 2008$, preveía la trasferencia de las principales funciones del Alto Comisario "al Ministerio competente". Con el D.P.C.M. de 5 de agosto de 2008 y el D.P.C.M. de 2 de octubre de 2008, dichas funciones del Alto Comisario se han asignado al Departamento de la Función Pública en la Presidencia del Consejo de Ministros; en octubre de 2008, en el seno del Departamento de la Función Pública se ha creado al efecto un Servicio Anticorrupción y Trasparencia (S.A.e.T.). Es evidente cómo el S.A.e.T. se ha incorporado a la Presidencia del Consejo de Ministros y, por lo tanto, al seno del poder ejecutivo: esto genera una situación que, objetivamente, hace legítimas las dudas sobre la subsistencia de las necesarias garantías de independencia e imparcialidad de tercero del controlador con respecto al controlado. La L. n. ${ }^{\circ} 116$ de 3 de agosto de 2009, al ratificar en Italia la Convención ONU de Mérida contra la corrupción, en el art. 6, titulado “Autoridad nacional anticorrupción”, ha establecido lacónicamente que "se designa autoridad nacional en el sentido del artículo 6 de la Convención el sujeto al que se han trasferido las funciones del Alto Comisario para la prevención y la detección de la corrupción y demás formas de actos ilícitos en el seno de la administración pública, en el sentido del artículo 68, párrafo 6-bis, del decreto-ley $n .^{\circ} 112$ del 25 de junio de 2008, traspuesto, con modificaciones, por la ley n. ${ }^{\circ} 133$ del 6 de agosto de 2008. Al sujeto mencionado en el párrafo 1 se le aseguran autonomía e independencia en la actividad". En la actualidad, por tanto, las principales funciones de prevención de la corrupción administrativa quedan confiadas al S.A.e.T., sin que esté prevista ninguna sistematización orgánica de las relaciones entre éste y la CiVIT, en el ínterin instituida con el paquete de medidas de la 'Reforma Brunetta'. Sobre la compleja evolución normativa que ha llevado de la supresión del Alto Comisario a la creación del S.A.e.T., véase la contribución de G. Sciullo, L'Alto Commissario per la prevenzione e il contrasto della corruzione e delle altre forme d'illecito all'interno della pubblica amministrazione e il Servizio anticorruzione e trasparenza (SAeT), en L. Vandelli (encargado), Etica pubblica e buona amministrazione: quale ruolo per i controlli?, Milán, Franco Angeli, 2009, pp. 71 ss. 


\title{
4. UNA HIPÓTESIS RECONSTRUCTIVA: EL PRINCIPIO DE OBJETIVIDAD COMO DIMENSIÓN ESPECÍFICA Y AUTÓNOMA DEL “POLITOPO" DE LA IMPARCIALIDAD ADMINISTRATIVA
}

Al llegar al término del recorrido de reconocimiento relacionado con el principio constitucional de imparcialidad, es posible intentar plantear el problema de la relación entre "imparcialidad" y "objetividad" de la administración.

\author{
Sobre este punto, sin embargo, es necesario establecer una premisa.
}

Un reciente proyecto de ley en materia de “Prevención y represión de la corrupción y de la ilegalidad en la administración pública", aprobado por el Senado el 15 de junio de 2011 y, en el momento en que esto se escribe, bajo examen de la Cámara de los Diputados (A.C. 4434), prefigura un intento de racionalización del marco de competencias, atribuyendo el papel de Autoridad nacional a la anticorrupción a la CiVIT, pero manteniendo algunas funciones específicas a cargo del Departamento de la Función Pública. En particular, el actual texto del art. 1 del Proyecto de ley está formulado así:

“1. En aplicación del artículo 6 de la Convención de la Organización de Naciones Unidas contra la corrupción, adoptada por la Asamblea General de la ONU el 31 de octubre de 2003 y ratificada en el sentido de la ley $n .^{\circ} 116$ del 3 de agosto de 2009 y de los artículos 20 y 21 de la Convención penal sobre la corrupción, celebrada en Estrasburgo el 27 de enero de 1999, la presente ley identifica, en el ámbito nacional, a la Autoridad nacional anticorrupción y a los demás órganos encargados de desarrollar, con modalidades tales que aseguren la acción coordenada, actividades de control, de prevención y de comprobación sobre el fenómeno de la corrupción y de la ilegalidad en la administración pública.

2. La Comisión para la valoración, la trasparencia y la integridad de las administraciones públicas que trata el artículo 13 del decreto legislativo n. ${ }^{\circ} 150$ del 27 de octubre de 2009, actúa como Autoridad nacional anticorrupción en el sentido del párrafo 1. En particular, la Comisión: a) colabora con los organismos paritarios extranjeros, con las organizaciones regionales e internacionales competentes; b) aprueba el Plan nacional anticorrupción elaborado por el Departamento de la función pública que trata el párrafo 4, letra c); c) ejerce la vigilancia y el control sobre la aplicación efectiva y sobre la eficacia de las medidas adoptadas por las administraciones públicas en el sentido de los párrafos 4 y 5; d) informa al Parlamento, presentando un informe antes del 31 de diciembre de cada año, sobre la actividad de comprobación del fenómeno de la corrupción y de la ilegalidad en la administración pública y sobre la eficacia de las disposiciones vigentes en la materia.

3. Para el ejercicio de las funciones que se mencionan en el párrafo 2, letra c), la Comisión puede ejercer poderes de inspección pidiendo noticias, informaciones, actas y documentos a las administraciones públicas, y ordena el cese de comportamientos o actos contrarios a los planes que tratan los párrafos 4 y 5 .

4. El Departamento de la función pública, también siguiendo líneas de orientación adoptadas por el Comité interministerial establecido y regulado por decreto del Presidente del Consejo de ministros: a) coordina la aplicación de las estrategias de prevención y comprobación de la corrupción y de la ilegalidad en la administración pública elaboradas a escala nacional e internacional; b) promueve y define normas y metodologías comunes para la prevención de la corrupción, coherentes con las orientaciones, los programas y los proyectos internacionales; c) sobre la base de los planes de las administraciones públicas centrales, establece el Plan nacional anticorrupción según figura en el párrafo 5, también con objeto de asegurar la actuación coordenada de las medidas que trata la letra a); d) define modelos estándar de las informaciones y de los datos necesarios para perseguir los objetivos previstos por la presente ley, según modalidades que permitan su gestión y análisis informatizado.

5. Las administraciones públicas centrales definen y trasmiten al Departamento de la función pública: a) planes de acción propios que suministran una valoración del diverso grado de exposición al riesgo de corrupción de las oficinas; b) las intervenciones de organización para prevenir el riesgo del que trata la letra a); c) procedimientos apropiados para seleccionar y formar, en colaboración con la Escuela superior de administración pública, a los empleados destinados a actuar en sectores particularmente expuestos a la corrupción, previendo, en esos mismos sectores, la rotación de directivos y funcionarios". 
Si se examinan las opiniones de la doctrina italiana, la noción de "objetividad" se refiere a la administración pública de formas muy diferentes.

Por ejemplo, hay quien entiende el "principio de objetividad" de la acción administrativa como "principio fundamental de la funcionalización del poder administrativo para los fines predeterminados por la ley" ${ }^{\prime 31}$.

Aceptando esta interpretación, el principio de objetividad se lleva al campo del principio de legalidad en sentido sustancial y se resuelve, en particular, en el vínculo de finalidad impuesto por la ley a la administración: de esta forma, la objetividad no parece capaz de conquistar un espacio conceptual autónomo con respecto a la legalidad.

Por otro lado, un filón acreditado de pensamiento, que se remite al magisterio de Benvenuti y que varios autores como Berti y Pastori han desarrollado en varias direcciones (pero que también, aunque partiendo de perspectivas diferentes, ha sido desarrollado por autores como Palma o Sala), configura la "objetividad" (u "objetivación”) como un rasgo de identidad del ser y del actuar de la administración pública como tal ${ }^{132}$.

131 Así A. Massera, La riforma della l. 241/1990 e le prospettive aperte, en Id. (encargado), La riforma della Legge 241/1990 sul procedimento amministrativo: una prima lettura, en http://www.astrid-online.it, 2005, p. 9.

132 Las referencias bibliográficas serían muy numerosas. Aquí nos limitaremos a recordar, con respecto a la temática de la objetividad de la administración, las de F. Benvenuti: Funzione amministrativa, procedimento, processo, en Riv. trim. dir. pubbl., 1952, pp. 118 ss. (ahora en F. Benvenuti, Scrittigiuridici, cit., vol. II [1948/1959], pp. 1126 ss.); Appunti di diritto amministrativo. Parte generale, Padua, Cedam, 1959, en particular pp. 31 ss., 89 ss., 169 ss.; L'ordinamento repubblicano, Venezia, Libreria universitaria, 1965, pp. 200 ss.; L'amministrazione oggettivata: un nuovo modello, en Riv. trim. sc. amm., 1978, pp. 6 ss.; Ancora per un'amministrazione obiettivata e Ancora per un'amministrazione obiettivata: conclusioni, en Aa.Vv., Studi economico-giuridici, vol. XLIX, 1978-1979, tomo III, Milán, Giuffrè, 1980, pp. 209 ss. y pp. 247 ss. (los tres últimos ensayos citados se han publicado ahora en F. Benvenuti, Scritti giuridici, cit., vol. IV [1970/1983], respectivamente en las pp. 3467 ss., 3584 ss. e 3591 ss.); Semantica di funzione, en Jus, 1985, pp. 3 ss. (ahora en F. Benvenuti, Scritti giuridici, cit., vol. V [1984/1999], pp. 3875 ss.); Disegno dell'Amministrazione Italiana, cit., en particular pp. 237 ss. y p. 244. Di G. Berti: La pubblica amministrazione come organizzazione, cit., passim pero, en particular, pp. 15 ss., 59 ss., 108, 290, 266 ss., 297 ss. y 411; Procedimento, procedura, partecipazione, en Aa.Vv., Studi in memoria di Enrico Guicciardi, Padua, Cedam, 1975, pp. 779 ss.; La struttura procedimentale dell'amministrazione pubblica, en Dir. soc., 1980, pp. 437 ss.; Il dedalo amministrativo e il diritto, en Jus, 1996, pp. 285 ss.; La scienza del diritto amministrativo nel pensiero di F. Benvenuti, allí 2000, pp. 3 ss.; La parabola dell'amministrazione pubblica e l'insegnamento del diritto amministrativo, La sovranità dell'ordine giuridico e Figure del diritto pubblico e loro connessioni, en Id., Diritto amministrativo. Memorie e argomenti, Padua, Cedam, 2008, respectivamente en las pp. 1 ss., 127 ss., 217 ss. Di G. Pastori: La procedura amministrativa, cit., passim; La burocrazia, cit., en particular pp. 88 ss.; Il procedimento amministrativo tra vincoli formali e regole sostanziali, en U. Allegretti - D. Sorace - A. Orsi Battaglini (encargado), Diritto amministrativo e giustizia amministrativa nel bilancio di un decennio di giurisprudenza, Rimini, Maggioli, 1987 , vol. II, pp. 806 ss. (v. en particular p. 812), y Riforme istituzionali e concezioni dell'amministrazione, en Aa.vv., Scritti in onore di Luigi Mengoni. Le ragioni del diritto, tomo III, Milán, Giuffré, 1995, pp. 2079 ss. (las dos últimas contribuciones citadas están ahora en G. Pastori, Scritti scelti, Nápoles, Jovene, 2010, respectivamente en el vol. I en las pp. 361 ss. y en el vol. II en las pp. 537 ss.); Prospettive attuali del diritto amministrativo, cit., en particular pp. 390 ss.; Feliciano Benvenuti e il diritto amministrativo del nuovo secolo, en Jus, 2008, pp. 323 ss. 
Esta orientación parte de una crítica radical a las concepciones subjetivistas tradicionales, propensas a poner en el centro de la escena a las personas jurídicas públicas, entendidas como autoridades, y a concebir el poder administrativo en términos de una situación jurídica subjetiva monopolizada por los sujetos públicos.

A esta visión se contrapone la objetiva. Ésta parte de algunos conceptos clave: el poder es energía jurídica que no pertenece a cada sujeto público, sino que emana del ordenamiento (el derecho objetivo), el cual es expresión de la soberanía de la sociedad de las personas, por lo que cada sujeto público no es dueño, sino receptor del poder; la función es una dinámica objetiva de trasformación del poder en acto jurídico y de efusión del potencial de la energía del ordenamiento, que se convierte en realización concreta en la sociedad a través de la disposición; la disposición administrativa es la forma de la función; el exceso de poder es el vicio de la función.

Esta concepción innovadora de la administración (propugnada hoy en día por la doctrina que se inspira en ese magisterio, por mucho que sea criticada por otra parte de la doctrina), propone una noción de "objetividad" que abarca en su integridad la organización y la actividad administrativa.

Si se entiende la "objetividad" en este sentido, es evidente que ésta absorbe totalmente en sí misma el principio constitucional de imparcialidad ${ }^{133} \mathrm{y}$, además, re-

Sobre el pensamiento de Benvenuti y de Berti, en particular, véanse los dos ensayos de U. Allegretti, Nuovi modi di concepire l'amministrazione: "l'amministrazione oggettivata" secondo Feliciano Benvenuti e Sentieri verso nuovi traguardi: "l'amministrazione capovolta" di Giorgio Berti, entrambi en L'amministrazione dall'attuazione costituzionale alla democrazia partecipativa, cit., respectivamente en las pp. 191 ss. e 215 ss.

Sobre la "objetivación" y la "objetivización" de la actividad administrativa en el pensamiento de G. Palma, véase Id., Itinerari, cit., pp. 266 ss., 276 ss., 289 y, sobre todo, 360 ss.

Sobre la "objetividad" de la acción administrativa en el pensamiento de G. Sala, véase Id., II principio del giusto procedimento, cit., pp. 101 ss. y Potere amministrativo e principi dell’ordinamento, cit., pp. 173 ss. e 303 ss.

133 De hecho, por ejemplo F. Benvenuti, L'amministrazione oggettivata: un nuovo modello, cit., p. 3477, adscribe a la administración el carácter "de la objetividad o, lo que es lo mismo, de la imparcialidad que la Constitución le asigna como característica fundamental”. G. Berti, La pubblica amministrazione come organizzazione, cit., p. 108, identifica la objetividad como "consistencia fundamental" de la imparcialidad y afirma que la administración imparcial es la administración objetiva. G. Pastori, La procedura amministrativa, cit., p. 65, equipara imparcialidad y objetividad de la decisión administrativa y, en /l procedimento amministrativo tra vincoli formali e regole sostanziali, cit., p. 812, afirma que "la decisión es imparcial en la medida en que deriva de una cuestión identificada como objetiva". G. Sala, II principio del giusto procedimento, cit., pp. 102-103, afirma que "la imparcialidad de la administración se debe investigar... en la objetivación... por lo tanto, la imparcialidad se realiza... en la objetividad “, definiendo la "imparcialidad como exigencia de objetividad de la acción administrativa” y afirmando que "no es seriamente impugnable que la objetividad constituya una connotación esencial de la acción administrativa"; el mismo Sala (op. cit., p. 105), habla al respecto de "principio constitucional de imparcialidad-objetividad". G. Palma, Itinerari, cit., p. 276, afirma que la "objetivización de la acción... encuentra en el art. 97 Const., es decir, en el dogma de la imparcialidad, su primer principio". Para P. Forte, I/ principio, cit., pp. 31-32, la “exigencia de objetivización de la función administrativa ... en el lenguaje constitucional, encuentra una síntesis en las dos expresiones, imparcialidad y buen desarrollo ... la imparcialidad, sea lo que sea que signifique en términos jurídicos, responde plenamente a la exigencia a la que hemos aludido en repetidas ocasiones, recurriendo a la locución resumida de objetivización". Sobre la relación entre imparcialidad y objetividad véanse también las observaciones de D. Vaiano, La riserva di funzione amministrativa, cit., y allí la jurisprudencia referida en la p. 312, nota 79. 
presenta un rasgo fundamental, un predicado necesario, la forma misma del deber ser de la administración.

Sin poner en discusión las varias acepciones en las que el término "objetividad" ha sido utilizado por parte de la doctrina, en este punto se pretende destacar un dato diferente.

Si se examina la forma en la que el propio término se utiliza a menudo en los pronunciamientos jurisprudenciales y en las fuentes normativas en relación con la actividad administrativa, parece surgir la propensión, por parte de derecho vivo, a:

- circunscribir a un significado más específico el alcance de la "objetividad" administrativa;

- calificar explícitamente la "objetividad", asumida en este significado más limitado, como "principio" que rige la actividad administrativa.

Más en particular, ya de la somera reseña normativa y jurisprudencial expuesta retro, en el párrafo 2, aflora una línea de tendencia sobre cuya base el "principio de objetividad" resulta en general asociado a la recurrencia del esquema siguiente:

(i) los órganos administrativos se encuentran obligados a expresar un juicio, caracterizado por márgenes de discrecionalidad administrativa o técnica, con objeto de elegir entre más soluciones que chocarán favorable o desfavorablemente con una plataforma de sujetos privados y pondrán a algunos de ellos en una posición privilegiada o inferior con respecto a los demás;

(ii) los órganos administrativos, antes de expresar el juicio discrecional y de llevar a cabo la elección, tienen la obligación de fijar previamente unos criterios, a los que se autovinculan para desempeñar posteriormente la actividad de valoración, de forma que hagan que el resultado (póstumo) del juicio se pueda comparar con el metro (preventivo) del juicio mismo, en términos de coherencia y consecuencialidad entre el primero y el segundo.

Por tanto, el "principio de objetividad", asumido en este uso más circunscrito, consiste en la autodeterminación debida, preventiva y analítica, por parte de la administración pública, de metodologías vinculantes, en el plano paramétrico y procedimental, para la asunción de posteriores elecciones valoradoras no íntegramente vinculadas ex lege.

Si se entiende así, el "principio de objetividad" del que se está hablando llega a coincidir con una norma que desde hace tiempo está en la mira de la doctrina administrativista, la cual, sin embargo, le atribuye denominaciones diferentes: "limitación de la discrecionalidad para la actuación de la imparcialidad administrativa" a través 
de la “fijación previa de parámetros de referencia”"134; “autolímite de la administración pública”"135; "predeterminación de las decisiones administrativas" a través de su “formación gradual”"136. La norma se contempla también en la ley general sobre procedimiento administrativo n. ${ }^{\circ} 241$ de 1990, en el art. 12, la cual, sin embargo, se refiere solo a algunas disposiciones (las que atribuyen ventajas económicas) ${ }^{137}$.

Independientemente de su denominación, esta norma, que aquí se propone caracterizar (en consonancia con el uso cada vez más difundido en el derecho vivo) como "principio de objetividad"138 de la acción administrativa, se considera claramente una consecuencia derivada del principio de imparcialidad indicado en el art. 97 Const. ${ }^{139}$.

134 Se alude a las contribuciones de P. Virga, La limitazione della discrezionalità per l'attuazione della imparzialità amministrativa, en AA.Vv., Studi in onore di Gioacchino Scaduto, vol. V, Padua, Cedam, 1970, pp. 170 ss.; Id., Eccesso di potere per mancata prefissione dei parametri di riferimento, en Aa.Vv., Scritti in onore di Massimo Severo Giannini, cit., I, pp. 585 ss.

135 P.M. Vipiana, L'autolimite della pubblica amministrazione. L'attività amministrativa fra coerenza e flessibilità, cit.

136 A. Police, Trasparenza e formazione graduale delle decisioni amministrative, cit.; Id., La predeterminazione delle decisioni amministrative. Gradualità e trasparenza nell'esercizio del potere discrezionale, Nápoles, ESI, 1997.

137 El art. 12 de la L. 241/1990, titulado “Disposiciones que atribuyen ventajas económicas”, reza:

“1. La concesión de subvenciones, contribuciones, subsidios y ayudas financieras y la atribución de ventajas económicas de cualquier género a personas y a entidades públicas y privadas están subordinadas a la predeterminación y a la publicación por parte de las administraciones de las que proceden, en la forma prevista por los ordenamientos respectivos, de los criterios y las modalidades a los que las propias administraciones deben atenerse.

2. La observancia efectiva de los criterios y de las modalidades de las que trata el párrafo 1 debe resultar de las disposiciones concretas relativas a las intervenciones que menciona ese mismo párrafo 1".

Para un comentario reciente sobre dicha disposición, con amplias referencias bibliográficas, véase $S$. Lariccia, I provvedimenti attributivi di vantaggi economici, en M.A. Sandulli (encargado), Codice dell'azione amministrativa, cit., pp. 572 ss.

138 Nótese que A. Police, La predeterminazione delle decisioni amministrative, cit., pp. 163-164 e pp. 208209, define la "predeterminación de la actividad administrativa" y "las formas de surgimiento preventivo y progresivo de las elecciones parciales" precisamente como “objetivación de la acción administrativa” “ “proceso de objetivación en el ejercicio del poder", afirmando que la predeterminación de los criterios absuelve a la función de “objetivar la acción administrativa”. En el mismo sentido, en cuanto al autolímite de la administración pública como "aspecto, de no poca importancia, en el proceso de objetivización de la actividad administrativa" y "potente medio" para realizar el "modelo de administración objetivada”, P.M. Vipiana, L'autolimite della pubblica amministrazione, cit., pp. 213-221.

139 La derivación del principio constitucional de imparcialidad del llamado "autolímite”, o sea de la predeterminación de los criterios de decisión por parte de la administración pública, está prácticamente asentada en la doctrina. Véase, entre los numerosos defensores en este sentido, P. Virga, La limitazione della discrezionalità per l'attuazione della imparzialità amministrativa, cit., passim; Id., Eccesso di potere per mancata prefissione dei parametri di riferimento, cit., p. 585; C. Mortati, Istituzioni di diritto pubblico, I, Padua, Cedam, 1975, p. 594; G. Sala, I/ principio del giusto procedimento, cit., pp. 130 ss.; P.M. Vipiana, L'autolimite della pubblica amministrazione, cit., pp. 143 ss.; F. Satta, capítulo Imparzialità della pubblica amministrazione, cit., p. 6; L. Torchia, Il controllo pubblico della finanza privata, Padua, Cedam, 1992, pp. 472 ss., S. Cassese, Le basi del diritto amministrativo, Milán, Garzanti, 2000, p. 319; Id. (encargado), Istituzioni, cit., p. 13; G. Rossi, Diritto amministrativo. I. Principi, cit., p. 132; L.R. Perfetti, Amministrazione pubblica e diritto amministrativo, cit., p. 15; E. Casetta, Manuale, cit., p. 48.

Debe señalarse la autorizada opinión de A. Police, La predeterminazione delle decisioni amministrative, cit. El Autor, en las pp. 63-67, afirma que la predeterminación de los criterios de la decisión discrecional por parte de la administración pública se vincula estrechamente al principio constitucional de imparciali- 
Efectivamente, existen características que parecen capaces de cualificar el principio de objetividad (entendido en el sentido estricto arriba indicado) como dimensión específica y autónoma dentro del "politopo" del principio de imparcialidad.

La objetividad participa en la naturaleza de la imparcialidad dado que, como esta última, tiende a la máxima limitación posible de la parcialidad.

La parcialidad administrativa se puede definir, como resultado de esta somera investigación, destacando su doble cara.

Por un lado, se puede configurar como atención excesiva o unión impropia con respecto a intereses particulares ajenos al fin público: esta forma se podría definir como parcialidad por hipervaloración de los intereses ajenos.

Por otro lado, opuesto, se puede mostrar como ignorancia y desinterés por todos los intereses particulares diferentes del público primario atribuido por la ley a la administración pública, es decir, como parcialidad por hipovaloración de los intereses ajenos.

En definitiva, la imparcialidad encuentra su núcleo identificativo en el vínculo fundamental de no estar al servicio de un único interés, tanto si este último es propio como si es ajeno ${ }^{140}$.

dad; en todo caso, en las pp. 67-73 subraya que "el primer fundamento de las formas de predeterminación de la acción administrativa” se debería identificar, además de en el principio de imparcialidad, sobre todo en el principio de buena fe objetiva y de tutela del legítimo encargo de los ciudadanos. Esto es así en tanto que el principio de imparcialidad podría constituir, ex se, el fundamento de la obligación de prefijar los criterios por parte de la administración pública, pero no de la obligación de externalizarlos y hacer que los ciudadanos los puedan conocer: entonces, esta última obligación se explicaría considerando que "la tutela del encargo no es solo el efecto característico de la predeterminación de cánones de conducta, sino que también es su función típica, la razón que justifica la previsión”. El argumento podría ser reversible: la tutela del encargo es posterior a la consolidación de la situación de encargo confiado, no preventiva respecto al surgimiento de dicha situación; la autodeterminación de los criterios por parte de la administración pública no está precedida de una confianza del ciudadano, que si acaso surge después de la predeterminación; esta última también es necesaria cuando no se haya generado, previamente al momento de la predeterminación de los criterios, alguna confianza legítima; la raíz del fenómeno de la predeterminación, por lo tanto, no debería residir en el principio de tutela de la confianza (que puede faltar), sino en el principio de imparcialidad, el cual opera constantemente, prescindiendo de la presencia o de la ausencia de un encargo. En cuanto a la obligación de la administración pública de hacer que los ciudadanos puedan conocer los criterios de su propio juicio inmediatamente después de haberlos predeterminado, dicha obligación, más que al principio de tutela del legítimo encargo, se podría remitir a los principios de trasparencia y de publicidad, los cuales, como se ha visto en el apartado 3.4, se pueden reconducir al principio constitucional de imparcialidad.

140 Es interesante observar, incidentalmente, cómo esta concepción de la imparcialidad se aproxima a aquella "ética de la imparcialidad" que, en una reciente y profunda reflexión, se ha identificado como necesaria, más en general, para el "jurista” que trate de asumir plenamente su propio papel en la sociedad pluralista. La referencia es de F. Cerrone, In margine ai Principia iuris di Luigi Ferrajoli, en Costituzionalismo. it (en la dirección URL http://www.costituzionalismo.it/articolo.asp?id=362), 2011 (Art. 7): "por lo tanto, la tarea del jurista está inmersa en la historia, está históricamente condicionada, pero no está, o no debería estar al servicio de un solo interés. Esta imparcialidad del jurista quizá se pueda entender como principio 
Como se ha visto, las “técnicas” de reducción de la parcialidad administrativa, generadas dinámicamente por el principio indicado en el art. 97 Const., son múltiples.

Par intentar minimizar la parcialidad por hipervaloración, por ejemplo, existen instrumentos que intentan reducir o en todo caso encauzar por vías correctas el papel de las preferencias y de los condicionamientos de la política (el principio de distinción entre política y administración; la norma del concurso público para el acceso a los empleos públicos); conjuntos de normas que alejan de raíz de ciertas posiciones o decisiones a los funcionarios o administradores que se encuentren en situación de conflicto de intereses (el deber de abstención; los mecanismos de incompatibilidad); normas que imponen a los empleados públicos obligaciones de comportamiento minuciosas y puntuales en la vida cotidiana, también fuera del trabajo (como las establecidas por varios códigos éticos o códigos de comportamiento), capaces de prevenir la implicación impropia en intereses privados de otros sujetos en comunicación con la administración pública; sanciones (como las impuestas tras el resultado de los procedimientos disciplinarios) o desincentivos económicos que aseguren formas eficaces de castigo de los comportamientos de los funcionarios contrarios al principio de integridad personal, etc.

Por otra parte, para evitar la parcialidad por hipovaloración, llega el apoyo de toda la detallada instrumentación de la imparcialidad en su dimensión positiva o inclusiva, a través de las normas vinculadas al principio de la participación procedimental, así como los principios de trasparencia, publicidad y obligación de motivación, que garantizan su efectividad y controlabilidad.

En el complejo mosaico de la imparcialidad, el principio de objetividad (en la acepción arriba escogida y especificada) ocupa un puesto peculiar.

De hecho, la técnica de reducción de la parcialidad propia del principio de objetividad es la de la desubjetivación de las valoraciones discrecionales de la administración pública.

Esto es así independientemente del hecho de que se trate de discrecionalidad pura, técnica o mixta: el principio de objetividad (pero no el más amplio de imparcialidad $^{141}$ ) queda ajeno al área de la actividad administrativa íntegramente vinculada,

ético fundamental de su actividad, principio que remite a su implicación en la historia y con los valores, pero también a una tradición de actividad práctica...".

141 El principio de imparcialidad que trata el art. 97 Const. opera también en todos los "procedimientos sin disposiciones", allí donde no haya discrecionalidad administrativa en cuanto al acto final que se ha de asumir (la llamada actividad administrativa vinculada) porque "el legislador ya ha descrito cada cosa": incluso en dichos casos, debiendo la administración pública obtener y reconstruir en su integridad y globalidad los hechos y los intereses (el "caso real”) a los que aplicar las prescripciones legislativas, "podrá existir (más aún, con frecuencia existirá) administración sin poder, pero nunca administración para fines públicos sin procedimiento administrativo y determinación de las reglas y de los principios que lo disciplinan", el primero de los cuales es el principio de imparcialidad (las expresiones citadas entre comillas están sacadas de L.R. Perfetti, I/ procedimento amministrativo, cit., en particular pp. 666, 677, 679-680 y 682). 
dado que, en ese caso, la exigencia de desubjetivación de la elección, a través del establecimiento de los criterios y métodos de decisión, es defendida y garantizada de forma suficiente por el principio de legalidad.

Sin embargo, hace falta ponerse de acuerdo en cuanto al sentido de la objetividad como desubjetivación del juicio discrecional.

La desubjetivación propia de la objetividad no se refiere a los sujetos autores de la valoración administrativa (los órganos y los funcionarios públicos), sino a los sujetos destinatarios de la valoración misma (las personas físicas y jurídicas que dialogan con la administración pública y cuyos intereses llegan a estar condicionados por ésta).

Este último punto se debe precisar mejor.

No se debe confundir el principio de objetividad con una utopía: la de una elección discrecional realizada por sujetos (los hombres que componen los órganos administrativos), los cuales, al valorar, logran despojarse de su filtro de "sujetos", poniéndose como espejos capaces de reflejar sin ninguna deformación los "objetos" contemplados, de elegir de forma robotizada, impersonal, impermeable a los valores propios de cada hombre sumergido en una sociedad y en una cultura.

La imposibilidad de una elección valorativa sin la previa adhesión a un sistema de valores y, por tanto, sin el filtro de la subjetividad, se ha destacado desde hace tiempo, por lo menos a partir de las conocidísimas reflexiones de Max Weber sobre las dicotomías ser/tener que ser, conocer/valorar y hecho/valor ${ }^{142}$.

El órgano administrativo de valoración (monocrático o colegial), cuando procede a la autolimitación preventiva de los criterios, de los indicadores, de los métodos que aplicará, no hace más que poner al descubierto y aclarar las directrices de su propia subjetividad valorativa: sustancialmente muestra primero las preferencias, las orientaciones, las jerarquías de valores que en todo caso guiarían su juicio discrecional después ${ }^{143}$.

142 Véanse en particular los ensayos L'"oggettività" conoscitiva della scienza sociale e della politica sociale (1904) y Il significato della "avalutatività" delle scienze sociologiche ed economiche (1917), en M. Weber, II metodo delle scienze storico-sociali (trad. al it. a cargo de P. Rossi), Turín, Einaudi, 1958, respectivamente en las pp. 52 ss. y las pp. 309 ss.

143 Para salir de lo genérico, considérese el caso en el que se trate de valorar el mejor examen realizado en una selección pública. No es indiferente que, al predefinir los criterios sobre cuya base se preferirá a un candidato y no a otro, la comisión examinadora premie, por ejemplo: el grado de análisis y de amplitud de la tarea más que la capacidad de síntesis y de brevedad; la cantidad de problemas tratados más que la elegancia de la forma expresiva; la capacidad del candidato para dedicarse a una reconstrucción histórica completa del tema más que el grado de conocimiento de las últimas actualizaciones; el hecho de que el candidato haya proporcionado la respuesta que la comisión considera correcta más que el hecho de que el candidato haya considerado todas las diversas soluciones alternativas al problema, expresando su propia preferencia por una respuesta distinta a la preferida por la comisión; la innovatividad de las tesis defendidas por el candidato más que el conocimiento demostrado sobre la situación, etc. Es indiferente el peso, en términos de distribución de la puntuación máxima, que la comisión asigne a los diversos criterios 
Si se trata de una subjetividad declarada preventivamente, y no de una subjetividad negada, entonces ¿en qué sentido se puede hablar de objetividad como desubjetivación?

No desde el punto de vista de los autores, naturalmente, sino desde el punto de vista de los destinatarios.

Los criterios de juicio autodeterminados preventivamente, de hecho, son objetivos porque son indiferentes a la subjetividad de las personas que sufrirán la valoración: son desubjetivados porque se preestablecen independientemente de a quién se juzgue, hasta el punto de ser repetibles y aplicables a cualquier sujeto que se encuentre ante los órganos administrativos de valoración, que será premiado o penalizado sobre la base no de ser Fulano o Mengano, sino de su capacidad de responder más o menos a las características objetivas (calidad, cantidad, títulos, experiencias, resultados de pruebas) prefiguradas en los criterios de valoración.

La enucleación del principio de objetividad así entendido, como una dimensión autónoma del "politopo" de la imparcialidad administrativa, hace entrever la perspectiva de esa "formación gradual de las decisiones administrativas" a través del "surgimiento progresivo de las elecciones parciales", destacado hace tiempo por la mejor doctrina ${ }^{144}$, y lanza un haz de luz sobre el proceso, demasiadas veces obscuro, que vincula el momento "intelectivo" al momento "volitivo", el conocimiento a la elección, en la dinámica de la actividad administrativa discrecional.

En suma, incluso cuando la ley no lo imponga expresamente, el principio de imparcialidad será el que generará la obligación, para cada órgano administrativo, de alejar de sí misma la patología de la parcialidad estableciendo previamente los métodos y cánones se su propio juicio discrecional.

De esta forma, la administración pública, al quedar como sujeto entre sujetos, no cautivará a estos últimos ni será cautivada por éstos, encontrando la cifra de su objetividad en una apertura plena e integral a la intersubjetividad, según un modelo que, aún hoy, encuentra su fórmula conceptual más acertada en la expresión "parte imparcial”.

\section{NOTA BIBLIOGRÁFICA}

Por razones de síntesis, las indicaciones bibliográficas se limitan a algunas contribuciones específicamente dedicadas al principio de imparcialidad administrativa.

que ella misma haya predefinido. Cada criterio y cada peso incorporan en símismos un juicio de valor, inevitablemente subjetivo por estar vinculado a la diversidad de orientaciones culturales de las personas que componen el órgano de valoración: diversidad imposible de eliminar en organizaciones públicas pluralistas, abiertas, multiculturales.

144 A. Police, La predeterminazione delle decisioni amministrative, cit., pp. $77 \mathrm{ss}$. 
U. Allegretti, L'imparzialità amministrativa, Padua, Cedam, 1965.

U. Allegretti, entrada Imparzialità e buon andamento della pubblica amministrazione, en Dig. disc. pubbl., Turín, UTET, 1993, VIII, pp. 131 ss.

V. Angiolini, Imparzialità, legalità e procedimento, en Le Regioni, 1984, pp. 519 ss.

P. Barile, Il dovere di imparzialità della pubblica amministrazione, en Scritti giuridici in memoria di Pietro Calamandrei, vol. IV, Padua, Cedam, 1958, pp. 25 ss.

R. Caranta, Art. 97, en R. Bifulco - A. Celotto - M. Olivetti (a cargo de), Commentario alla Costituzione, Vol. II, Turín, UTET, 2006, pp. 1889 ss.

S. Cassese, Imparzialità amministrativa e sindacato giurisdizionale, Milán, Giuffrè, 1973

A. Cerri, Imparzialità ed indirizzo politico nella pubblica amministrazione, Padua, Cedam, 1973.

B. Di Giacomo Russo, Concorso pubblico, principio di imparzialità e costituzione amministrativa nella giurisprudenza della Corte costituzionale, en Quad. reg., 2004, pp. 645 ss.

P. Forte, L'imparzialità come struttura della decisione pubblica amministrativa, en Aa.Vv., Procedura, procedimento e processo (actas del Congreso, Urbino 14 y 15 de junio de 2007), Padua, Cedam, 2010, pp. 403 ss.

M. Galdi, Buon andamento, imparzialità e discrezionalità amministrativa, Nápoles, Liguori, 1996.

G. Gardini, Imparzialità amministrativa e nuovo ruolo della dirigenza pubblica, en Dir. amm., 2001, pp. 39 ss.

G. Gardini, L'imparzialità amministrativa tra indirizzo e gestione, Milán, Giuffré, 2003.

G. Gardini, entrada Imparzialità amministrativa, en S. Cassese (dirigido por), Dizionario di diritto pubblico, vol. IV, Milán, Giuffré, 2006, pp. 2934 SS.

G. Gardini, L'imparzialità tra attività e organizzazione amministrativa, en Aa.Vv., Procedura, procedimento e processo (actas del Congreso, Urbino 14 y 15 de junio de 2007), Padua, Cedam, 2010, pp. 379 ss.

R. Iannotta, La motivazione come modo di attuazione del principio di imparzialità amministrativa, en Aa.Vv., Scritti in onore di Costantino Mortati, vol. II, Giuffrè, Milán, 1977, pp. 197 ss.

S. Lariccia, Origini storiche e fondamento costituzionale del principio di imparzialità deIle pubbliche amministrazioni, en Aa.Vv., Studi in onore di Giorgio Berti, vol. II, Nápoles, Jovene, 2005, pp. 1377 ss.

G. Manfredi, Principio di imparzialità e riordino dell'amministrazione per collegi, en Dir. amm., 1996, pp. 89 ss.

F. Merloni, Amministrazione "neutrale" e amministrazione imparziale (a proposito dei rapporti tra "politica" e "amministrazione"), en Dir. pubbl., 1997, pp. 319 ss.

F. Merloni, Dirigenza pubblica e amministrazione imparziale: il modello italiano in Europa, Bolonia, II Mulino, 2006.

F. Merloni, Organizzazione amministrativa e garanzie dell'imparzialità. Funzioni amministrative e funzionari alla luce del principio di distinzione tra politica e amministrazione, en Dir. pubbl., 2009, pp. 57 ss.

G. Pastori, Amministrazione, imparzialità e composizione tecnica degli organi di amministrazione del personale, en Le Regioni, 1991, pp. 1504 ss.

C. Pinelli, II "buon andamento" e L'imparzialità" dell'amministrazione, en Commentario della Costituzione iniciado por G. Branca y continuado por A. Pizzorusso, La pub- 
blica amministrazione. Art. 97-98 Const. (a cargo de P. Caretti - C. Pinelli - U. Pototschnig - G. Long - G. Borrè), Bolonia - Roma, Zanichelli, 1994, pp. 31 ss.

C. Pinelli, Il principio di imparzialità nel pensiero di Aldo M. Sandulli, in Aa.Vv., Aldo M. Sandulli (1915-1984). Attualità del pensiero giuridico del Maestro, Giuffrè, 2004, pp. 253 ss.

A. Pubusa, Considerazioni sull'imparzialità amministrativa nella L. 7 agosto 1990, n. 241, en Aa.Vv., Scritti in onore di Pietro Virga, Tomo II, Milán, Giuffré, 1994, pp. 1437 ss.

G. Sala, Imparzialità dell'amministrazione e disciplina del procedimento nella recente giurisprudenza amministrativa e costituzionale, en Dir. proc. amm., 1984, pp. 433 ss.

L. Sandulli Napoleoni, L'imparzialità dell'azione amministrativa, en Foro amm., 1986, pp. 2404 ss.

F. Satta, entrada Imparzialità della pubblica amministrazione, en Enc. giur., Roma, Treccani, vol. XV, 1989

M.R. Spasiano, I principi di pubblicità, trasparenza e imparzialità, en M.A. Sandulli (encargado), Codice dell'azione amministrativa, Milán, Giuffré, 2011, pp. 83 ss.

N. Speranza, Il principio di buon andamento-imparzialità dell'amministrazione nell'art. 97 della Costituzione, en Foro amm., 1972, pp. 79 ss.

S. Spuntarelli, Il principio di legalità e il criterio di imparzialità nell'amministrare, en Dir. amm., 2008, pp. 223 ss.

J.B. Vera, Imparzialità vs. indirizzo politico: le variabili del rapporto tra politica e amministrazione nella dinamica delle istituzioni, en Dir. amm., 2007, pp. 15 ss.

P. Virga, La limitazione della discrezionalità per L'attuazione della imparzialità amministrativa, en AA.Vv., Studi in onore di Gioacchino Scaduto, vol. V, Padua, Cedam, 1970, pp. 170 ss. 